Reports on the Marine Brology of the Sudanese Red Sea.-XXI. On the Brachyura. By R. Douglas Laurie, M.A. (Oxon.), Lecturer in Embryology and Senior Demonstrator in Zoology in the University of Liverpool. (Communicated by Prof. W. A. Herdman, F.R.S., F.L.S.)

(Plates 42-45 and 5 Text-figures.)

[Read 18th June, 1914.]

THE collection comprises 65 species, of which 1 , Chlorodopsis arabica, is new to science and 8 are new to the Red Sea. The latter are Cryptodromia gilesii (Alc.), Notopus dorsipes (Fabr.), two varieties of Lambrus (Aulacolambrus) hoplonotus, Ad. \& Wh., Chlorodopsis arabica, Laurie, n. sp., Actumnus setifer (de Haan), var.tomentosus, Dana, Litocheira integra (Miers), Macrophthalmus graeffei, A. M.-Edw., and Palicus whitei (Miers). In addition, the very decided variety cytherea of Chlorodiella niger (Forsk.) is new to the Red Sea, and should perhaps be reinstated in the specific rank originally given to it by Dana.

Of the genera named above, 2 are new to the Red Sea fauna, namely, Litocheira and Notopus, and the latter is the first recorded Red Sea representative of the family Raninidæ.

The material in the collection helps in the elucidation of the following, in addition to other points of interest :-

Thalamita chaptalii and $T$. poissonii, both of Audouin and Savigny, 1826, are easily separable species.

Lambrus (Aulacolambrus) hoplonotus, Ad. \& Wh., will, I think, be found to comprise at least two species.

Macrophthalmus inermis, A. M.-Edw., is, I believe, incorrectly considered by Alcock to be a synonym of $M$. concewus, Stm. See note under $M$. grarffei, A. M.-Edw.

Ophthalnias curvirostris (A. M.-Edw.) is, I believe, quite a good species, easily distinguishable from $O$. cervicornis (Herbst). In addition to a series of other points of difference, I call attention to the figures which I give of the external maxillipedes in the two forms. There is in my mind a doubt as to the correctness of the single record of $O$. cervicornis from the Red Sea.

My specimens confirm Nobili's suggestion that Dotilla affinis, Alc., 1900, is a synonym of $D$. sulcata (Forsk., 1775). I find that the supposed distinction was in part based upon a sex-difference.

Chlorodopsis wood-masoni, Alc., 1898, is a doubtful synonym of $C^{\gamma}$. spinipes (Hell., 1861). 
The possible identity of Actaca polyaeantha (Hell., 1861) with $A$. peronii (H. M.-Edw:, 1834) is a point requiring investigation.

A study of certain growth-changes has been made in the 40 specimens of the common species Chlorodiella niger (Forsk.), as also in Trapezia cymodoce (Herbst), and less fully in Phymodius sculptus (A. M.-Edw.) and some others.

Lupa alcocki (Nob., 1905), Herbstia corniculata, Klunz., 1906, and Maerophthalmus graeffei, A. M.-Edw., 1873, have hitherto been known only by their type-specimens, and of each of the two latter species the present collection contains the first recorded male example.

Caphyra monticellii, Nob., and Lupa alcocki (Nob.), are here figured for the first time.

Other interesting forms in the collection include Nucia pulchella (A. M.Edw.), Cyphocarcinus minutus, A. M.-Edw., and Thalamita (Thalamatö̈des) tridens, var. spinigera (Nob.).

Workers on Red Sea Brachyura will find two publications indispensable as a starting-point, namely, Alcock's 'Materials for a Carcinological Fauna of India' and Nobili's 'Faune Carcinologique de la Mer Rouge.' Nobili records all species known from the Red Sea at the time of his writing in 1906. Klunzinger the same year published his 'Spitz- und Spitzmundkrabben des Roten Meeres,' seen by Nobili when the latter had completed the body of his work, and reviewed briefly by him in an appendix. Klunzinger gives some useful descriptions and translations of some of Paulson's Russian descriptions. He considers Acanthonyx consobrinus of Paulson as a synonym of $A$. elongatus, Miers, so that $A$ : consobrinus, A. M.-Edw., is to be deleted from Nobili's enumeration, and he adds the following 7 species to the Red Sea fauna, namely, Simocarcinus camelus, Klunz., Herbstia corniculata, Klunz., Herbstia contiguicornis, Klunz., Heterocrypta petrosa, Klunz., Parthenope acuta Klunz., Eumedonus convictor, Bouv. et Seu., and Hyastenus brockii, de Man, of which the first five were new to science. Including the 8 species added by the present paper, the revised list in Table I. shows a total of 260 species recorded from the Red Sea.

The Red Sea Brachyuran fauna forms an integral part of the Brachyuran fauna of the Indo-Pacific region. To emphasize this, I have associated with the following complete list of Red Sea species a table showing to what extent they have been recorded in certain representative districts within the region. It will be noted from the headings of the columns that the records are exhaustive for some districts, while for others they refer to a single important collection from the district named. 
TABLE I.

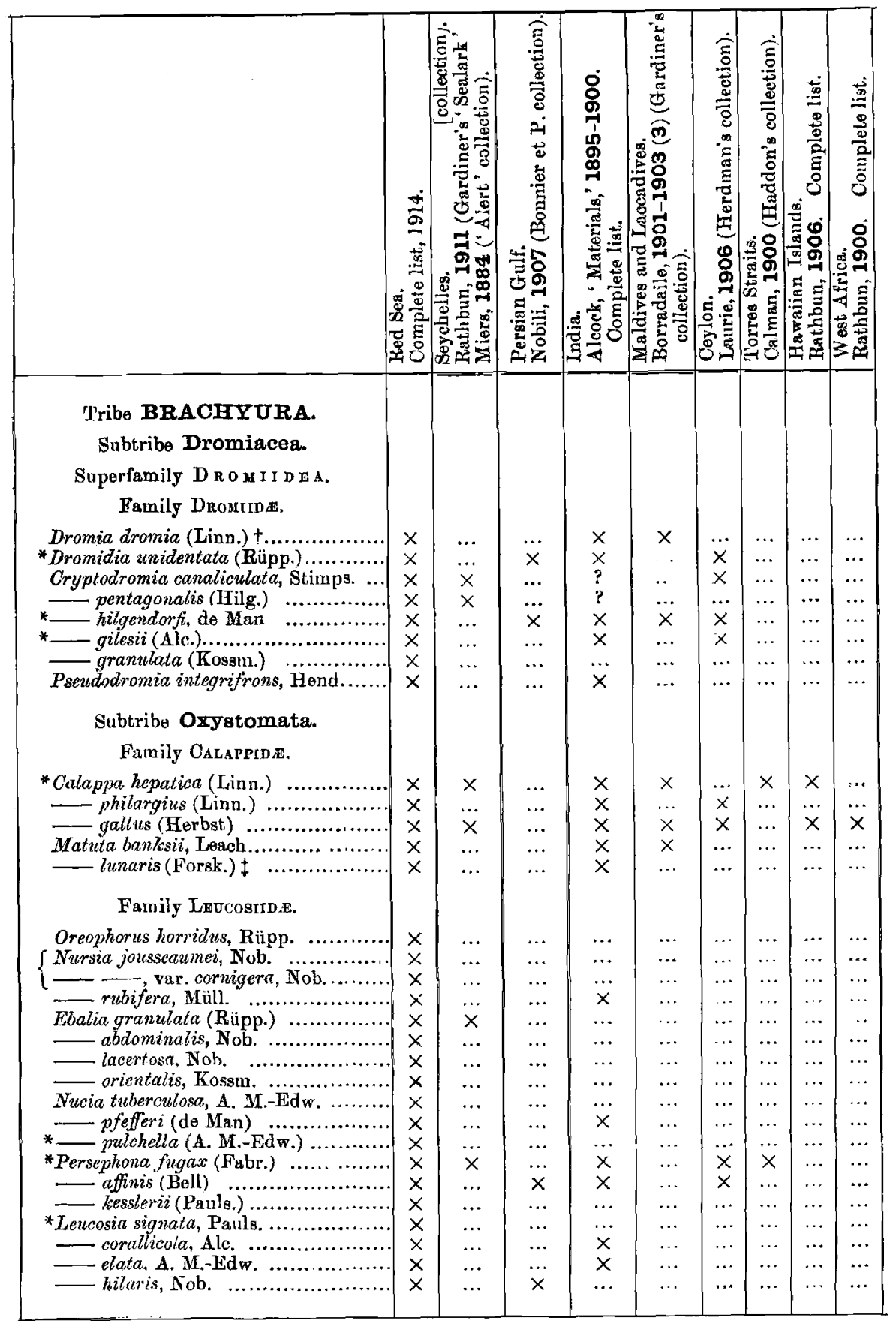

* Includea in present collection.

$+=D$, rumphii, Fabr.; see Rathbun, 1902, p. 32 , and Ihle, 1913, p. 22.

$+=M$. victor (Fabr.); see Stebbing, 1905 (1) p. 54. 
TABLE I. (con.).

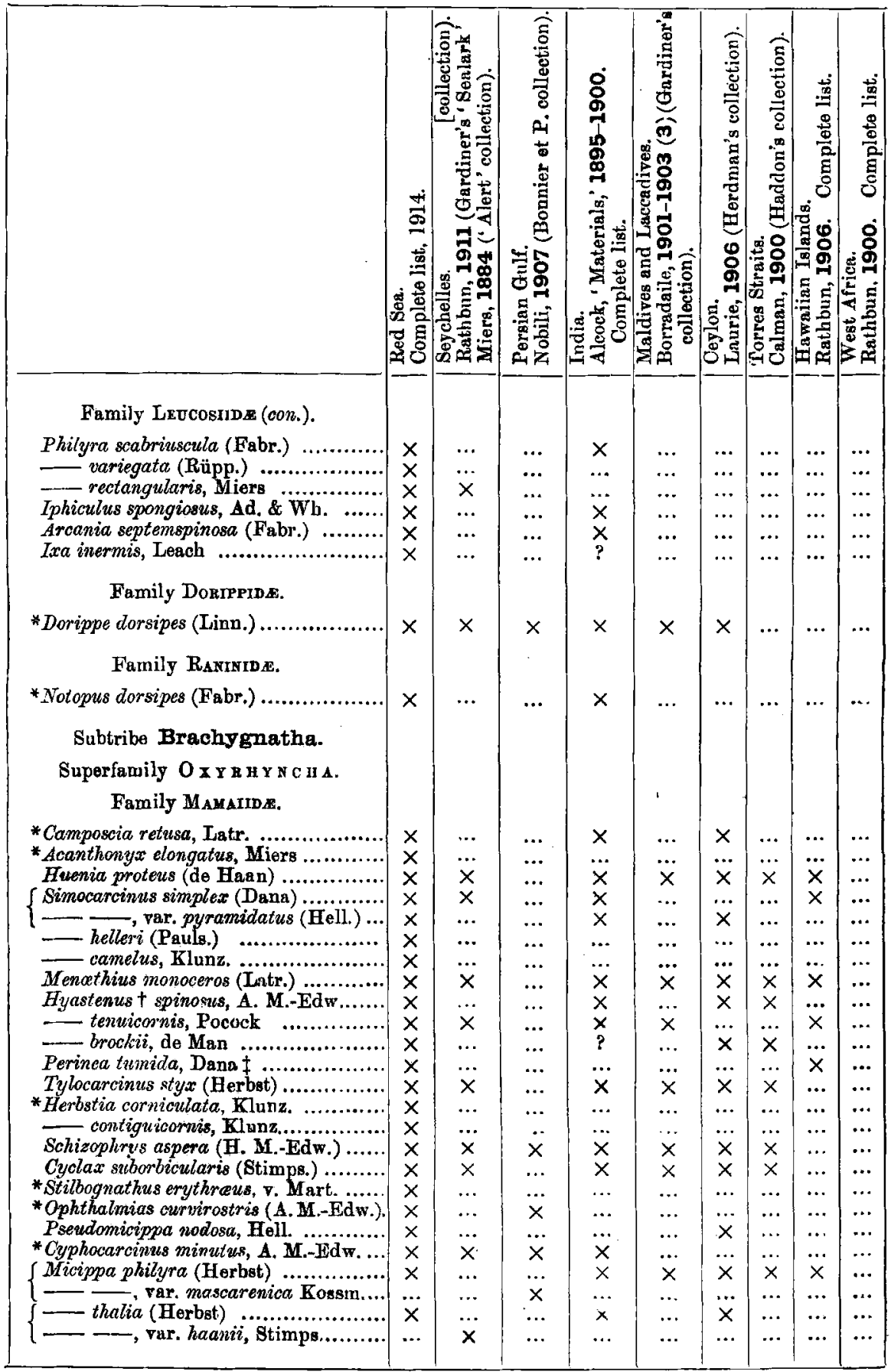

+ No evidence that this genus= Halimas, Lutr.; Beo Calman, 1913, p. 313.

$\ddagger=$ Parathoë rotundata, Miers; see Onlman, 1909, p. 713. 
Table I. (con.).

\begin{tabular}{|c|c|c|c|c|c|c|c|c|c|}
\hline ' & 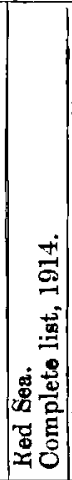 & 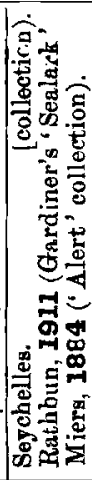 & 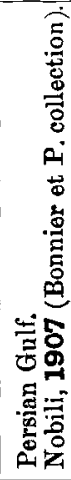 & 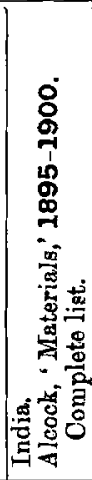 & 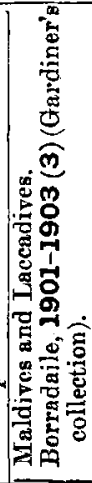 & 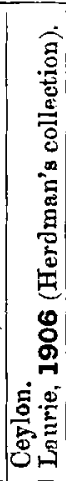 & 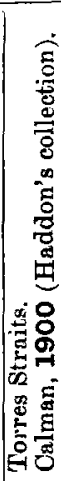 & 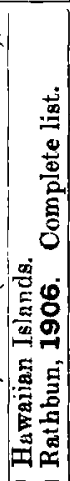 & 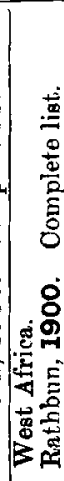 \\
\hline Family Parthenopida, & & & & & & & & & \\
\hline * Parthenope horrida (Linn.) & $x$ & $x$ & $\cdots$ & $x$ & $\cdots$ & ... & $\cdots$ & $x$ & ... \\
\hline r. acuta, Klunz. ............. & $x$ & $\ldots$ & $\cdots$ & $\cdots$ & $\cdots$ & $\cdots$ & $\ldots$ & $\cdots$ & $\cdots$ \\
\hline Lambrus (Thyrolambrus) leprosus, Nob. & $x$ & $\cdots$ & $\cdots$ & $\cdots$ & $\cdots$ & $\cdots$ & $\cdots$ & $\cdots$ & .. \\
\hline - (Platylambrus) carinatus, H. & $x$ & $\ldots$ & ... & $x$ & $\cdots$ & $x$ & ... & $\cdots$ & $\cdots$ \\
\hline $\begin{array}{r}\text { (Aulacolambrus) pisoides, Ad. } \\
\& \mathrm{Wh} .\end{array}$ & $x$ & $\ldots$ & ... & $\cdots$ & $\cdots$ & $\cdots$ & $\cdots$ & $\cdots$ & $\cdots$ \\
\hline *__ _ hoplonotus, Ad. \& Wh. ...... & $x$ & $x$ & ... & $x$ & .. & $x$ & $x$ & $x$ & $\cdots$ \\
\hline *___ (Rhinolambrus) pelagicus, Rüpp. & $x$ & $\ldots$ & ... & $x$ & $x$ & $x$ & $\ldots$ & $\cdots$ & $\cdots$ \\
\hline - - (Psendolambrus) calappoides ( & $\cdot \mid \begin{array}{l}x \\
x\end{array}$ & $\dddot{x}$ & $\ddot{x}$ & $\dddot{x}$ & $\dddot{x}$ & $\ddot{x}$ & $\dddot{x}$ & $\ddot{x}$ & $\cdots$ \\
\hline \& Wh.) & & & & & & & & & 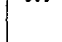 \\
\hline Heteroerypta petrosa, Klunz. ............ & $\cdot x$ & $\cdots$ & $\cdots$ & $\cdots$ & $\cdots$ & $x$ & $\cdots$ & $\cdots$ & $\cdots$ \\
\hline Eumedonus convictor, Bour, et Seu. ... & $=x$ & .. & $\cdots$ & $\cdots$ & $\cdots$ & $\cdots$ & $\cdots$ & $\cdots$ & $\cdots$ \\
\hline 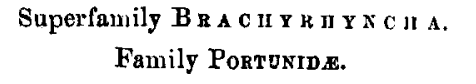 & & & & & & & & & \\
\hline Carcinides $†$ manas (Linn.) & $x$ & $\cdots$ & ... & $x$ & $\cdots$ & $\cdots$ & ... & $x$ & $\cdots$ \\
\hline Fortunus $\ddagger$ subcorrugatus (A. M.-Edw.) & $x$ & $\cdots$ & $\ldots$ & ... & .. & $\ldots$ & $\ldots$ & $\cdots$ & $\ldots$ \\
\hline Lissocarcinus orbicilaris, Dana ......... & $x$ & $x$ & ... & $x$ & $x$ & $x$ & $x$ & $x$ & ... \\
\hline${ }^{\star}$ Caphyra monticellii, Nob. ................ & $x$ & ... & $\cdots$ & $\cdots$ & $\cdots$ & $\cdots$ & $\cdots$ & $\cdots$ & $\cdots$ \\
\hline Caripa lavita (Hell.) & $\mid x$ & $\ddot{z}$ & $\cdots$ & $\dddot{y}$ & $\cdots$ & $\cdots$ & $\cdots$ & $\dddot{x}$ & $\cdots$ \\
\hline 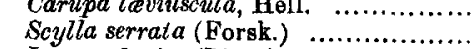 & $\begin{array}{l}x \\
x\end{array}$ & $\begin{array}{l}x \\
\ldots\end{array}$ & $\cdots$ & $\begin{array}{l}x \\
x\end{array}$ & $\begin{array}{l}\cdots \\
\cdots\end{array}$ & $\begin{array}{l}\cdots \\
\cdots\end{array}$ & $\begin{array}{l}\cdots \\
\ldots\end{array}$ & $\begin{array}{c}x \\
\ldots\end{array}$ & $\cdots$ \\
\hline 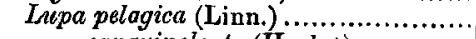 & $x$ & $\cdots$ & $x$ & $\widehat{x}$ & $\cdots$ & $x$ & $x$ & $\ldots$ & ... \\
\hline — sanguinolenta (Herbst) ...... & $x$ & $\cdots$ & $x$ & $x$ & $\cdots$ & $x$ & $x$ & $x$ & ... \\
\hline — longispinosa (Dana) .............. & $x$ & $x$ & $\cdots$ & $x$ & $x$ & $\cdots$ & $\ldots$ & $x$ & ... \\
\hline _- - arabica videns (Lau.)...... & $\cdots$ & $\cdots$ & $\ddot{\partial}$ & $\cdots$ & $\cdots$ & $x$ & .. & $\cdots$ & *. \\
\hline 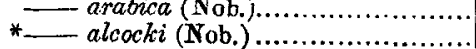 & $\stackrel{x}{x}$ & $\cdots$ & $\begin{array}{l}x \\
\ldots\end{array}$ & $\cdots$ & ... & $\cdots$ & $\cdots$ & $\cdots$ & $\cdots$ \\
\hline _-granulata (H. М.-Edw.)....... & $\hat{x} \mathfrak{s}$ & $\dddot{x}$ & $\ldots$ & $\dddot{x} \xi$ & $\times \S$ & $\cdots$ & $\ddot{x}$ & $\ddot{x}$ & $\cdots$ \\
\hline — orbitosina (Rath.) ............. & $\cdots$ & $x$ & ... & $\cdots$ & ... & $\times \|$ & $\cdots$ & ... & $\ldots$ \\
\hline _. convexa (de Haan) .............. & $x$ & $\ldots$ & $\cdots$ & $x$ & $\cdots$ & $x$ & $\ldots$ & $\cdots$ & ... \\
\hline * Chaybdis erythrodacty la (Lam.) & $\ddot{x}$ & $x$ & $\ldots$ & $\ddot{x}$ & $\cdots$ & $\ldots$ & $\ldots$ & $x$ & ... \\
\hline _orientalis (Dana).................. & $x$ & $\cdots$ & $\ldots$ & $x$ & $\cdots$ & $x$ & $\ldots$ & $x$ & $\ldots$ \\
\hline —— hellerit (A. M.-Edw.) .......... & $x$ & $\cdots$ & $\cdots$ & $\ldots$ & $\cdots$ & $\cdots$ & .. & $\cdots$ & $\cdots$ \\
\hline — merguiensis (de Man)... & $x$ & $\cdots$ & $\cdots$ & $x$ & $\cdots$ & $\cdots$ & $\cdots$ & $\cdots$ & .. \\
\hline - sexdentata (Herbst) & $x$ & $\cdots$ & $\cdots$ & $x$ & $\cdots$ & $\cdots$ & $\cdots$ & $\cdots$ & $\cdots$ \\
\hline
\end{tabular}

+ Carcinides, Rathbun, $1897=$ Carcinus, Leach, 1814, et anct. ; see Rathbun, 1897, p. 164.

† Fabr., 1798. For ronacluption of Liocarcinus, Rath., see Steb. 1902, p. 11, and 1908, p. 11. \$ May be L. orfitosina (Rath., 1911); see Rathbun, 1911, p. 205.

i1 I have re-exumined an adult $\delta$ from off Mutwall Is. and 3 andult $\delta$ and $1 q$ ovig. from Gulf of Manaar recorded as grausulata and find that they come under orbitosina. 
TABle I. (con.).

\begin{tabular}{|c|c|c|c|c|c|c|c|c|c|}
\hline & 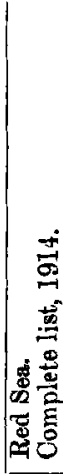 & 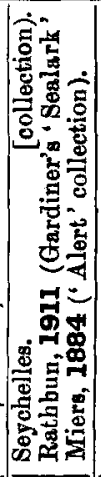 & 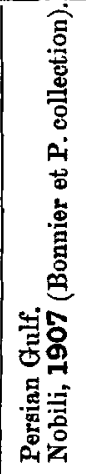 & 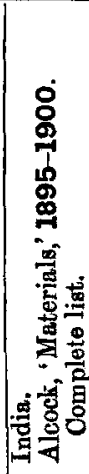 & 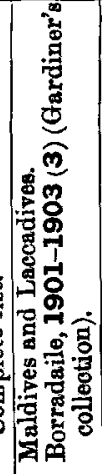 & 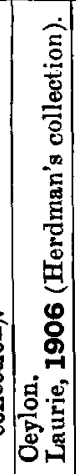 & 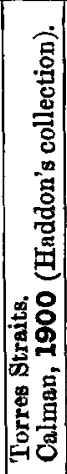 & 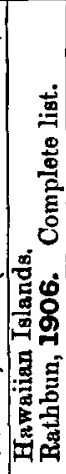 & 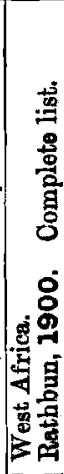 \\
\hline Family Portunida (cono). & & & & & & & & & \\
\hline Charybdis variegata (Fabr.) ............. & $x$ & & & $x$ & $\cdots$ & & ... & & $\cdots$ \\
\hline (Herbst)....................... & $x$ & $x$ & $x$ & $x$ & $\cdots$ & $x$ & $\cdots$ & $\cdots$ & ... \\
\hline Z heterodon, Nob. ............................. & $\frac{x}{x}$ & $\cdots$ & $\cdots$ & $\cdots$ & $\cdots$ & $\cdots$ & $\cdots$ & $\cdots$ & $\cdots$ \\
\hline 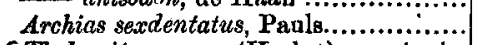 & $\hat{x}$ & & $\cdots$ & $\cdots$ & $\cdots$ & $\cdots$ & $\cdots$ & $\cdots$ & $\cdots$ \\
\hline (Thalamitaprymna (Herbst). var. typica & $x$ & $x$ & ... & $x$ & ... & $\ldots$ & $x$ & $\ldots$ & $\ldots$ \\
\hline - — var. annectans, Lau. ...... & $\mid \dddot{x}$ & & $\dddot{*}$ & & $\cdots$ & $x$ & $\cdots$ & $\cdots$ & $\cdots$ \\
\hline$\{$ ——, var. orsnata, Inatr. ........... & $x$ & $x$ & $x$ & $x$ & $\cdots$ & $\times$ & $\cdots$ & $\ldots$ & $\cdots$ \\
\hline 二 & $\mid x$ & $\begin{array}{l}x \\
x\end{array}$ & $\cdots$ & $\begin{array}{l}x \\
x\end{array}$ & $\underset{x}{x}$ & $\cdots$ & $\cdots$ & $\dddot{x}$ & $\cdots$ \\
\hline 二 , var. stimpsoni, $\mathrm{A}, \mathrm{M} .-\mathrm{Ed}$. & $\mid x$ & $\begin{array}{l}x \\
\ldots\end{array}$ & $\cdots$ & $x$ & $\begin{array}{l}x \\
\ldots\end{array}$ & $\cdots$ & $\dddot{x}$ & $\hat{\ldots}$ & $\ldots$ \\
\hline —_ chaptalii (Aud. ot Sav.)............ & $x$ & 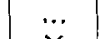 & 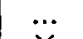 & $x$ & $\ldots$ & $x$ & ... & .. & ... \\
\hline *— poissonii (Aud. et Sav.) ............ & $x$ & $x$ & $x$ & $x$ & $x$ & $x$ & $\ldots$ & $\ldots$ & ... \\
\hline 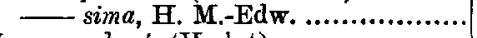 & $x$ & $x$ & $\cdots$ & $x$ & $x$ & ... & $x$ & $x$ & $\cdots$ \\
\hline _ admete (Herbst & $\cdots$ & $x$ & $\cdots$ & $\ddot{x}$ & $\dddot{x}$ & $\cdots$ & $\cdots$ & $x$ & $\cdots$ \\
\hline *_- ב, var. admete (Herbst) $\ldots \ldots$. & $\ddot{x}$ & $\cdots$ & $\dddot{x}$ & $\hat{x}$ & $\hat{x}$ & $\begin{array}{l}x \\
\ldots\end{array}$ & $\dddot{x}$ & $\cdots$ & $\cdots$ \\
\hline *__ — , var. intermedia, Borr...... & $x$ & $\cdots$ & ... & ... & $x$ & ... & $\cdots$ & ... & $\cdots$ \\
\hline - 一, var. $g$ & ... & ... & ... & ... & $x$ & ... & $\cdots$ & $\dddot{x}$ & $\cdots$ \\
\hline - —, rar. ed & - $\cdots$ & ... & $\cdots$ & $\cdots$ & ... & $\cdots$ & ... & $x$ & $\cdots$ \\
\hline - - var. $a$ & ... & $x$ & ... & $\cdots$ & $\cdots$ & $\cdots$ & $\cdots$ & $x$ & $\cdots$ \\
\hline - - var. margaritimana, Rath. & $\cdots$ & $x$ & ‥ & $\dddot{x}$ & $\cdots$ & $\cdots$ & $\cdots$ & $\cdots$ & • \\
\hline$\longrightarrow$ - , var. quadrilobata, Miers ... & & $x$ & $\cdots$ & $\underset{x}{x}$ & $\cdots$ & $\dddot{\ddot{~}}$ & & $\dddot{m}$ & $\cdots$ \\
\hline *__ integra, Dana : & $x$ & $x$ & .. & $x$ & $\cdots$ & $x$ & $\cdots$ & $x$ & $\dddot{\dddot{z}}$ \\
\hline - - , var. africana, Miers .... & $\ddot{x}$ & $\cdots$ & $\cdots$ & $\begin{array}{l}\cdots \\
\ldots\end{array}$ & $\cdots$ & $\cdots$ & $\cdots$ & $\ldots$ & $\begin{array}{l}x \\
\ldots\end{array}$ \\
\hline _ bandusia, Nob. ...... & $\hat{x}$ & $\cdots$ & $\ldots$ & ... & $\cdots$ & $\cdots$ & $\cdots$ & $\cdots$ & $\ldots$ \\
\hline $\begin{array}{r}\text { (Thalamitoides) quadridens, } \\
\text { M.-Edw. }\end{array}$ & $x$ & $\cdots$ & $\cdots$ & ... & $\ldots$ & ... & ... & $\ldots$ & $\cdots$ \\
\hline *——— tridens, A. M.-Edw.; var. & $x$ & ... & $\ldots$ & $\cdots$ & $\cdots$ & ... & $\cdots$ & $\cdots$ & $\cdots$ \\
\hline *Podophthalmus vigil (Fabr.). & $x$ & $\ldots$ & ... & $\cdots$ & $\cdots$ & $\cdots$ & $\cdots$ & $x$ & $\cdots$ \\
\hline Family XavtuIDs. & & & & & & & & & \\
\hline *Carpiliu & $x$ & $\times$ & $\cdots$ & $x$ & $x$ & ... & $x$ & $x$ & $\cdots$ \\
\hline${ }^{*}$ Carpilod & $x$ & & $\ldots$ & & & $\cdots$ & $\cdots$ & $\dddot{y}$ & $\ldots$ \\
\hline$=r u$ & $\underset{x}{x}$ & $\cdots$ & $\cdots$ & $\cdots$ & $x$ & $\cdots$ & $\cdots$ & $x$ & $\cdots$ \\
\hline 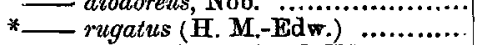 & $x$ & $x$ & $\ldots$ & $\ddot{x}$ & $\ddot{*}$ & $\ldots$ & $\ldots$ & $\ldots$ & $\cdots$ \\
\hline —vail & $x$ & $x$ & $\cdots$ & $x$ & $x$ & $\cdots$ & $\cdots$ & $x$ & $\cdots$ \\
\hline Trugipes (I & $x$ & $x$ & $\cdots$ & & & ... & $\ldots$ & $\cdots$ & $\cdots$ \\
\hline Liomera cinctin & $x$ & $x$ & $\cdots$ & $x$ & $x$ & $\ldots$ & $x$ & 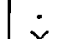 & $\cdots$ \\
\hline - pube & & & $\cdots$ & . & 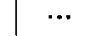 & $\cdots$ & $\cdots$ & $x$ & $\cdots$ \\
\hline - - var., Nol & $x$ & & $\cdots$ & ... & $\ldots$ & $\cdots$ & $\cdots$ & $\cdots$ & $\cdots$ \\
\hline
\end{tabular}


TABle I. (con.).

\begin{tabular}{|c|c|c|c|c|c|c|c|c|c|}
\hline & 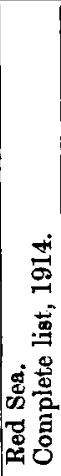 & 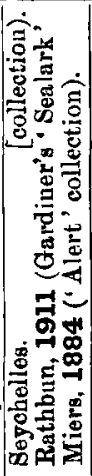 & 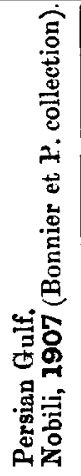 & 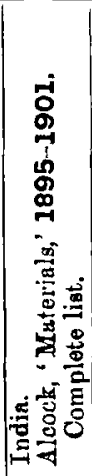 & 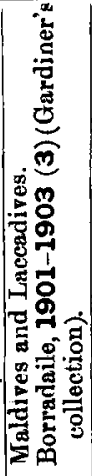 & 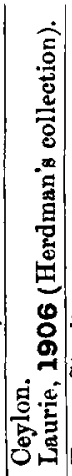 & 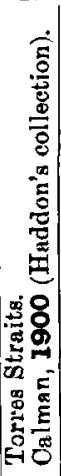 & 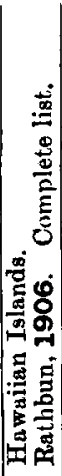 & 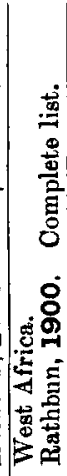 \\
\hline Family $\mathbf{X}_{\text {atThId }}$ a (con.). & & & & & & & & & \\
\hline Liomera themisto (de Man)....... & $x$ & $\cdots$ & $\cdots$ & ... & .. & ... & $\cdots$ & ... & ... \\
\hline $\begin{array}{l}\text { granosimana, A. M.-Edw... } \\
\text { Lioxantho punctatus (H. M.-Edn }\end{array}$ & $\begin{array}{l}x \\
x\end{array}$ & $x$ & $\cdots$ & $\dddot{x}$ & $\dddot{x}$ & $\ldots$ & $\cdots$ & $\cdots$ & $\cdots$ \\
\hline - tumidus, Alc. .................. & $\hat{x}$ & $\cdots$ & $\begin{array}{l}\cdots \\
\cdots\end{array}$ & $x$ & $\begin{array}{l}x \\
x\end{array}$ & $\cdots$ & $\cdots$ & $\cdots$ & $\cdots$ \\
\hline - asperutus, Alc. ......... & $x$ & $\cdots$ & $x$ & $x$ & $x$ & $\cdots$ & $\cdots$ & $\cdots$ & $\ldots$ \\
\hline * Atergatis roseus (Rüpp.) .... & $x$ & ... & ... & $x$ & $\cdots$ & $\cdots$ & ... & ... & ... \\
\hline — ocyroë (Herbst) $\bar{\uparrow}$........ & $x$ & ... & $\cdots$ & $x$ & $x$ & $\ldots$ & $x$ & $\cdots$ & ... \\
\hline -granulatus, de Man & $x$ & ... & $\ldots$ & ... & ... & $\ldots$ & ... & ... & ... \\
\hline Platypodia cristata (A. M.-Edw.) & $x$ & $x$ & $\cdots$ & $x$ & $x$ & .. & ... & $\ldots$ & $\ldots$ \\
\hline — granulosa (Rüpp.) .............. & $x$ & $\cdots$ & $\cdots$ & $x$ & $x$ & ... & $x$ & $x$ & ... \\
\hline — semigranosa ( & $x$ & $x$ & $\ldots$ & $x$ & $x$ & ... & $\ldots$ & $x$ & $\ldots$ \\
\hline *__ anaglypta (Hell.) ........... & $x$ & $x$ & $\cdots$ & $x$ & $x$ & $x$ & $\ldots$ & $\cdots$ & $\cdots$ \\
\hline Atergatopasis frauenfeldi (Hell.). & $x$ & $\cdots$ & ... & $\cdots$ & $\cdots$ & $\cdots$ & ... & $\ldots$ & ... \\
\hline granulatus, A. M.E.Edw. & $x$ & $x$ & $\ldots$ & $\ldots$ & $\ldots$ & $\ldots$ & ... & $x$ & ... \\
\hline "Zosimus aneus i] & $x$ & $x$ & $\ldots$ & $x$ & $x$ & $\ldots$ & ... & $\ldots$ & ... \\
\hline Zozymodes & $x$ & $\cdots$ & $\cdots$ & ... & $\cdots$ & $\ldots$ & $\cdots$ & $\cdots$ & ... \\
\hline pulchellus, A. M.-Edw.. & $x$ & $x$ & ... & $\cdots$ & .. & $x$ & ... & ... & ... \\
\hline Euxanthus sculptilis, Dana & $x$ & ... & $\ldots$ & $x$ & $\ldots$ & $\ldots$ & $\ldots$ & $\ldots$ & $\ldots$ \\
\hline Hypocolpus diverticulatus (Strahl) $\ddagger \ldots$ & $x$ & $x$ & ... & ... & ... & .. & ... & ... & $\cdots$ \\
\hline * Xantho distinguendus, de Haan ...... & $x$ & $\ldots$ & $\times$ & $x$ & $\cdots$ & $\times$ & $\cdots$ & ... & ... \\
\hline - hirt & $x$ & ... & $\ldots$ & $\ldots$ & $\ldots$ & ... & $\ldots$ & $\ldots$ & ... \\
\hline *__ hydrophilus (Herbst) & $x$ & $x$ & $x$ & $x$ & $\cdots$ & $x$ & $x$ & $x$ & ... \\
\hline Leptodius gracilis (Dana) & $x$ & $x$ & $\cdots$ & $\cdots$ & $\cdots$ & $\ldots$ & ... & $x$ & $\ldots$ \\
\hline$\longrightarrow$ sanguineus (H. M.-Edw.) & $x$ & $x$ & $\ldots$ & $x$ & $x$ & $\ldots$ & ... & $x$ & $\ldots$ \\
\hline - euglyptus (Alc.) & $x$ & $\cdots$ & ... & $x$ & $\cdots$ & ... & $\ldots$ & ... & ... \\
\hline cavipes (Dana & $x$ & $x$ & $\ldots$ & $x$ & ... & $\ldots$ & ... & $\ldots$ & $\ldots$ \\
\hline Cycloxanthops lineatus (A. M.-Edw.)... & $x$ & ... & ... & $x$ & $\cdots$ & $x$ & $\ldots$ & $\ldots$ & ... \\
\hline *Etisus lavima & $x$ & $x$ & $x$ & $x$ & $x$ & ... & $x$ & $x$ & $\ldots$ \\
\hline (H. M.-Edw.)..... & $x$ & $\ldots$ & $\ldots$ & $x$ & $x$ & $\ldots$ & ... & ... & $\ldots$ \\
\hline electra (Herbst) & $x$ & $x$ & $x$ & $x$ & $x$ & ... & $x$ & $x$ & ... \\
\hline Actca (Banareia) kraussi, Hell... & $x$ & $\cdots$ & ... & $\cdots$ & $\cdots$ & $\cdots$ & $\cdots$ & $\cdots$ & ... \\
\hline bella (Dana) & $x$ & ... & ... & $\cdots$ & ... & ... & ... & ... & ... \\
\hline tomentosa (H. M.-Edw.). & $x$ & $x$ & $\ldots$ & $x$ & $x$ & $\ldots$ & ... & $x$ & $\ldots$ \\
\hline${ }^{*}$ — hirsutissima (Rüpp.) ........ & $x$ & $x$ & ... & $x$ & $\cdots$ & $\cdots$ & ... & $x$ & ... \\
\hline mufopunctata (H. M.-Edw.) & $x$ & $x$ & $\cdots$ & $x$ & $x$ & .. & ... & $x$ & ... \\
\hline garretti, Rath. .... & $x$ & $x$ & ... & ... & ... & $\cdots$ & $\ldots$ & $x$ & $\ldots$ \\
\hline speciosa (Dana) ................... & $x$ & $x$ & ... & $x$ & $x$ & $x$ & ... & $x$ & ... \\
\hline sabcea, Nob............. & $x$ & $\cdots$ & $\cdots$ & $\cdots$ & $\cdots$ & $\cdots$ & $\cdots$ & $\cdots$ & ... \\
\hline hellerii, A. M.-Edw. & $x$ & $x$ & ... & $\because$ & $\cdots$ & $\cdots$ & $\cdots$ & $\cdots$ & .. \\
\hline nodulosa, Wh. . & $x$ & $x$ & $\ldots$ & $x$ & $\ldots$ & $\cdots$ & $\cdots$ & $x$ & 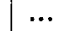 \\
\hline *__ polyacantha (Hell.)... & $x$ & $x$ & $\cdots$ & $\cdots$ & $\ldots$ & $\ldots$ & $\ldots$ & $\cdots$ & $\cdots$ \\
\hline pisiger & $x$ & $\cdots$ & $\cdots$ & $\cdots$ & $\cdots$ & $\cdots$ & $\cdots$ & $\cdots$ & $\cdots$ \\
\hline
\end{tabular}

$+=$ Atergatis floridus (Linn.); fide Rathbun, 1906, p. 845 .

$\ddagger=$ Cancer sculptus, H. M.-Edw., 1834; not Herbst, 1794. Fide Rathbun, 1911, p. 215. 
Table I. (con.).

\begin{tabular}{|c|c|c|c|c|c|c|c|c|c|}
\hline & 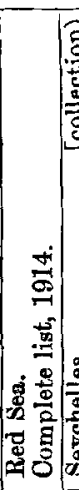 & 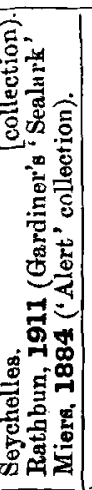 & 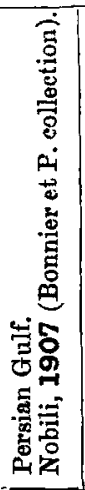 & 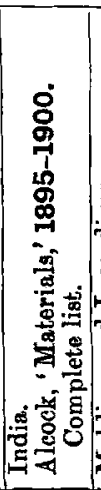 & 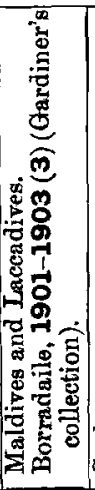 & 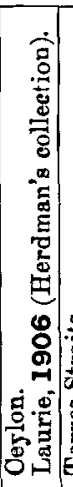 & 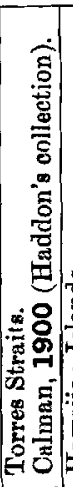 & 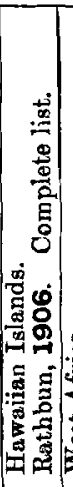 & 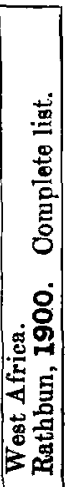 \\
\hline Family XAXTuIDa (con.). & & & & & & & & & \\
\hline$\left\{\begin{array}{l}* \text { Actea granulata }(A \\
\text { var can }\end{array}\right.$ & $x$ & $x$ & $x$ & $x$ & $x$ & $x$ & $\because$ & $\cdots$ & \\
\hline 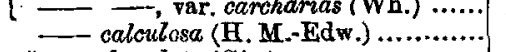 & $\dddot{x}$ & ... & ... & $\ddot{x}$ & $\ldots$ & $x$ & $\begin{array}{l}x \\
x\end{array}$ & & $\cdots$ \\
\hline *__ fossulata & $\hat{x}$ & $\cdots$ & $\dddot{x}$ & $\hat{x}$ & $\ddot{x}$ & $\ldots$ & & $\ldots$ & $\cdots$ \\
\hline$\{$ Chlorodiella & $x$ & $x$ & $x$ & $\times$ & $x$ & $\times$ & $x$ & $\times$ & \\
\hline$\left[{ }^{*}\right.$ _- bidentatus (Nob.) (Dana) & $\begin{array}{l}x \\
x\end{array}$ & $\begin{array}{l}\cdots \\
\ldots\end{array}$ & $\begin{array}{l}\ldots \\
\ldots\end{array}$ & $\begin{array}{l}\cdots \\
\cdots\end{array}$ & $\begin{array}{l}\cdots \\
\ldots\end{array}$ & $\ldots$ & $\begin{array}{l}\cdots \\
\cdots\end{array}$ & 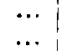 & $\begin{array}{l}\cdots \\
\cdots\end{array}$ \\
\hline - lipprs (Nob.) ...... & $\hat{x}$ & & $\ldots$ & $\ldots$ & & & & $\ldots$ & \\
\hline *Phymod & $\hat{x}$ & $x$ & $x$ & $x$ & $x$ & $\ldots$ & $x$ & $x$ & ... \\
\hline *- seulptu & $\underset{x}{x}$ & $x$ & $\mathrm{C}_{\mathrm{C}}$ & $\times$ & $x$ & $x$ & $x$ & $\cdots$ & $\cdots$ \\
\hline 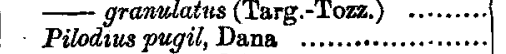 & $\begin{array}{l}x \\
?\end{array}$ & $\cdots$ & $\cdots$ & $\cdots$ & $\cdots$ & $\dddot{x}$ & $\cdots$ & $\cdots$ & $\cdots$ \\
\hline a & $x$ & $\ldots$ & $\cdots$ & $\ldots$ & $\ldots$ & ... & $\ldots$ & $\ldots$ & $\ldots$ \\
\hline$D M-F d w D$ & $\dot{x}$ & $x$ & $\cdots$ & $\dddot{x}$ & $\ldots$ & $\ddot{x}$ & $\cdots$ & $\dddot{x}$ & $\cdots$ \\
\hline * Chlorodops & $\stackrel{x}{x}$ & $x$ & $\cdots$ & $x$ & $\cdots$ & $\begin{array}{l}x \\
\ldots\end{array}$ & & 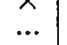 & $\cdots$ \\
\hline * _ spinipes (Hell.) .... & $\hat{x}$ & $x$ & $\ldots$ & $x$ & $x$ & $\ldots$ & $\times$ & $\ldots$ & $\cdots$ \\
\hline - frontalis (Dans) & $\hat{x}$ & $\cdots$ & ... & & $x$ & & $x$ & $\ldots$ & $\ldots$ \\
\hline$-(C y c$ & $x$ & $\dddot{m}$ & $\ldots$ & $x$ & $?$ & & & $\therefore$ & $\cdots$ \\
\hline * Cymo andreoss & $x$ & $\stackrel{x}{x}$ & $\stackrel{x}{x}$ & $x$ & & $\ldots$ & $x$ & $\cdots$ & $\cdots$ \\
\hline $\begin{array}{l}\text { actylus, de Hagn } \\
\text { ors .................. }\end{array}$ & $\begin{array}{l}x \\
x\end{array}$ & $\begin{array}{l}x \\
x\end{array}$ & $\begin{array}{c}\times \\
\ldots\end{array}$ & $\begin{array}{l}x \\
x\end{array}$ & $\stackrel{x}{x}$ & $\begin{array}{c}x \\
\ldots\end{array}$ & $\begin{array}{c}\times \\
\ldots\end{array}$ & $\cdots$ & $\begin{array}{ll}\ldots \\
\ldots\end{array}$ \\
\hline Menippe rumph & $\hat{x}$ & & $\cdots$ & $x$ & & & & & $\cdots$ \\
\hline Psendoziv & $x$ & $x$ & & $x$ & $x$ & $\cdots$ & $\cdots$ & $x$ & $\cdots$ \\
\hline & $x$ & $\cdots$ & $\cdots$ & (2) & $\cdots$ & & & $\ldots$ & $\cdots$ \\
\hline Ozius $r$ & $x$ & $\dddot{x}$ & $\dddot{x}$ & $\begin{array}{l}x \\
x\end{array}$ & $\cdots$ & $x_{x}^{x}$ & $\cdots$ & $\cdots$ & $\cdots$ \\
\hline M.-Edw.) . & $\underset{x}{x}$ & $\begin{array}{l}x_{x} \\
x\end{array}$ & & $\begin{array}{l}x \\
\ldots \\
\ldots\end{array}$ & 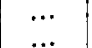 & $\times$ & & $\cdots$ & $\begin{array}{l}\ldots \\
\ldots\end{array}$ \\
\hline 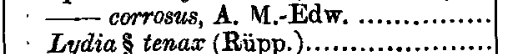 & $\begin{array}{l}x \\
x\end{array}$ & $\begin{array}{l}x \\
x\end{array}$ & $\ddot{x}$ & $\ddot{x}$ & $\cdots$ & $\ldots$ & $\cdots$ & $\begin{array}{l}\cdots \\
\cdots\end{array}$ & $\cdots$ \\
\hline Heteropilumnus fimbriatus (H. M.: & $\hat{x}$ & $\ldots$ & $\cdots$ & $\cdots$ & $\cdots$ & $\cdots$ & $\cdots$ & $\cdots$ & $\cdots$ \\
\hline Pilumnus trichophoroides, de Man... & $\cdots$ & $x$ & & ... & $\cdots$ & $\cdots$ & $\cdots$ & $\cdots$ & $\cdots$ \\
\hline-1 & $x$ & M & $x$ & ( & $\ldots$ & $\ldots$ & $\because$ & $\ldots$ & $\ldots$ \\
\hline - ve & $x$ & $\cdots$ & $\cdots$ & $x$ & $x$ & $\times$ & $\therefore$ & $x$ & $\cdots$ \\
\hline _- forsh & $x$ & $\ldots$ & $\dddot{x}$ & $\cdots$ & $\cdots$ & $\cdots$ & $\cdots$ & $\cdots$ & $\cdots$ \\
\hline * & $\underset{x}{x}$ & $\cdots$ & $\begin{array}{l}x \\
x\end{array}$ & $\cdots$ & $\begin{array}{c}\cdots \\
\cdots\end{array}$ & \begin{tabular}{l|l}
$\ldots$ \\
$\ldots$
\end{tabular} & $\cdots$ & $\ldots$ & $\cdots$ \\
\hline $\begin{array}{l}{ }^{*} \text { __ propi } \\
\text { _ }\end{array}$ & $\begin{array}{l}x \\
x\end{array}$ & $x$ & $\ldots$ & $?$ & $\ddot{x}$ & $\ldots$ & $\ldots$ & $\ldots$ & $\cdots$ \\
\hline de Man.. & $\hat{x}$ & & ... & $\cdots$ & $\cdots$ & $\cdots$ & $\cdots$ & $\cdots$ & $\cdots$ \\
\hline —L Iavim & $x$ & ... & $\cdots$ & $\cdots$ & ... & $\cdots$ & $\cdots$ & $\cdots$ & $\cdots$ \\
\hline - endan & $x$ & $\cdots$ & $\cdots$ & $\cdots$ & $\ldots$ & $\ldots$ & $\cdots$ & $\cdots$ & $\cdots$ \\
\hline$-s t$ & $x$ & $\ldots$ & $\ldots$ & $\cdots$ & $\ldots$ & $\cdots$ & $\cdots$ & .. & $\cdots$ \\
\hline Kossm. ... & $x$ & (- & $\cdots$ & $\cdots$ & $\cdots$ & $\cdots$ & $\cdots$ & $\cdots$ & $\cdots$ \\
\hline 二- schr & $\begin{array}{l}x \\
x\end{array}$ & $\cdots$ & $\cdots$ & $\cdots$ & $\cdots$ & $\ldots$ & \begin{tabular}{l|}
$\cdots$ \\
$\cdots$
\end{tabular} & $\ldots$ & $\cdots$ \\
\hline Actumnus globulus, & $\hat{x}$ & $\ddot{x}$ & $\ldots$ & $\ldots$ & $\cdots$ & $\ldots$ & $\ldots$ & $\cdots$ & $\cdots$ \\
\hline
\end{tabular}

+ It is doubtful how far anthors have distiuguighed in their records between $C$. ngger and var. cytherea.

$\ddagger=$ Etisodes frontalis, Dana; see Borradaile, 1902 (2), p. 261.

$\S=$ Eurüppellia, Miers; seo Rathbun, 1906, p. 862. 
TABIE T. (con.).

\begin{tabular}{|c|c|c|c|c|c|c|c|c|c|}
\hline & 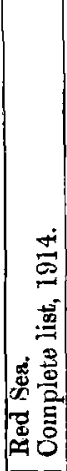 & 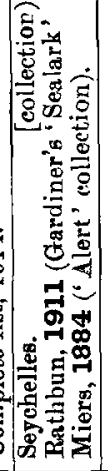 & 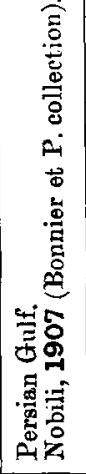 & 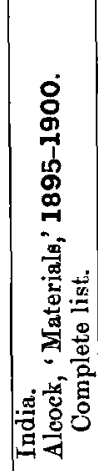 & 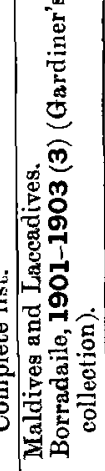 & 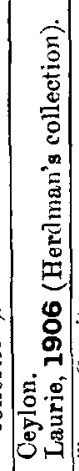 & 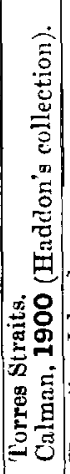 & 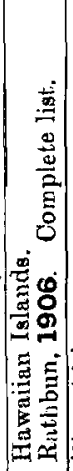 & 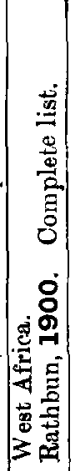 \\
\hline Family Xasthida (con.). & & & & & & & & & \\
\hline Actuninus setifer (de Haan) & & & $\cdots$ & $\cdots$ & $\cdots$ & $\cdots$ & $x$ & & \\
\hline - & ... & $x$ & $\cdots$ & $\dddot{m}>>>$ & $\dddot{\dddot{m}}+2>$ & $\ldots$ & ... & $\cdots$ & $\ldots$ \\
\hline $\begin{array}{l}\text { *__, var. setifer (do Haan). } \\
* \text { _ var, tomentosus, Dana. }\end{array}$ & $x$ & $\cdots$ & $\dddot{x}$ & $\stackrel{x}{x}$ & $\begin{array}{l}x \\
x\end{array}$ & $\begin{array}{l}x \\
x\end{array}$ & $\cdots$ & $\cdots$ & $\cdots$ \\
\hline __ var. amirantensis, Rath. & & $\dddot{x}$ & & $\ldots$ & $\ldots$ & $\hat{\ldots}$ & $\cdots$ & ... & $\cdots$ \\
\hline *__ bonnieri, Nob & $x$ & $x$ & $x$ & $\cdots$ & .. & $x$ & ... & 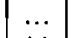 & ... \\
\hline 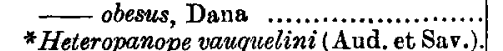 & $\begin{array}{l}x \\
x\end{array}$ & $x$ & $\begin{array}{l}\cdots \\
\cdots\end{array}$ & $\begin{array}{l}\cdots \\
\cdots\end{array}$ & $\cdots$ & $\begin{array}{l}\cdots \\
\ldots\end{array}$ & \begin{tabular}{l|l}
$\cdots$ \\
$\ldots$
\end{tabular} & $\times$ & $\ldots$ \\
\hline - pharconica, Nob. & $\hat{x}$ & $\cdots$ & $\ldots$ & $\ldots$ & $\ldots$ & $\ldots$ & $\cdots$ & $\cdots$... & $\cdots$ \\
\hline Eurycarcinus natalensis (Krauss) ...... & $x$ & $\ldots$ & $\cdots$ & ... & $\cdots$ & $\cdots$ & $\cdots$ & $\cdots$ & $\ldots$ \\
\hline orientalis, A, M.-Ed & $x$ & $\cdots$ & $\cdots$ & $\dddot{x}$ & $\cdots$ & $\cdots$ & $\cdots$ & .. & $\cdots$ \\
\hline $\begin{array}{l}\text { integrifrons, de } \mathrm{M} \\
\text { Eriphia sehana (Shaw) }+\end{array}$ & $x$ & $x$ & $\ldots$ & $\begin{array}{l}x \\
x\end{array}$ & $\dddot{x}$ & $\cdots$ & $\ldots$ & $\dddot{x}$ & $\cdots$ \\
\hline L var. smithii, Macl. ........... & $\dddot{x}$ & $\hat{x}$ & $\dddot{x}$ & $\hat{x}$ & $\ldots$ & $\ldots$ & $\ldots$ & $\ldots$ & $\ldots$ \\
\hline - scabricula, Dana. & $x$ & $x$ & $\dddot{x}$ & $x$ & $x$ & $\ldots$ & $\cdots$ & & $\cdots$ \\
\hline * Trapezia cymodoce (He) & $x$ & $x$ & $x$ & $x$ & $x$ & $x$ & $\times$ & $x$ & $\ldots$ \\
\hline —, var. ferr & $x$ & $x$ & $x$ & $x$ & $x$ & $\cdots$ & $\cdots$ & $\times$ & $\cdots$ \\
\hline - - var. areolat & $\dddot{x}$ & $\cdots$ & $\cdots$ & $x_{x}^{x}$ & $\dddot{x}$ & $x$ & $\times$ & $\cdots$ & $\cdots$ \\
\hline (*工二, var. gutcautata (Macl.)........ & $\hat{x}$ & $x$ & $\cdots$ & $\begin{array}{l}x \\
x\end{array}$ & $\begin{array}{l}x \\
x\end{array}$ & $\dddot{x}$ & $\cdots$ & $\dddot{x}$ & $\ldots$ \\
\hline - digitalis (Latr & $x$ & $x$ & 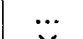 & $x$ & $x$ & $\ldots$ & $\ldots$ & $\times$ & $\ldots$ \\
\hline * Tetralia glaberrima $(\mathrm{He}$ & $x$ & $x$ & $x$ & $x$ & $x$ & $x$ & $x$ & $\cdots$ & $\cdots$ \\
\hline Quadrella coron & $\dddot{x}$ & $\times$ & $x$ & $x$ & $\cdots$ & $\cdots$ & $\cdots$ & $\ldots$ & $\cdots$ \\
\hline _ - , var. granulosa, Borr. .. & $\begin{array}{c}x \\
\ldots\end{array}$ & $\cdots$ & … & $\because$ & $\dddot{x}$ & $\dddot{x}$ & … & $\ldots$ & $\ldots$ \\
\hline $\bar{T}$, var. masul & & $x$ & $\cdots$ & $x$ & $\cdots$ & $\cdots$ & $\cdots$ & $\cdots$ & $\ldots$ \\
\hline Lybia denticulata, Nob. & $x$ & ... & $\cdots$ & $\cdots$ & $\cdots$ & $\cdots$ & $\cdots$ & $\cdots$ & $\cdots$ \\
\hline Family Goneplactd $x$. & & & & & & & & & \\
\hline$\{$ Eucrate crenata, de $\mathrm{Ha}$ & $x$ & $x$ & $x$ & $x$ & $\cdots$ & ... & $\cdots$ & $\ldots$ & $\cdots$ \\
\hline $\int_{*}-$, var. dentata (Stimps.), Ale. & $\underset{x}{x}$ & $\ldots$ & $\cdots$ & $x$ & 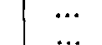 & $\cdots$ & $\cdots$ & $\dddot{x}$ & $\cdots$ \\
\hline * Litocheira integra (Miers) ................... & $\hat{x}$ & $\dddot{x}$ & $\ldots$ & $\dddot{x}$ & $\dddot{x}$ & $\ldots$ & $\ldots$ & $\ldots$ & $\ldots$ \\
\hline Paranoto & $\times$ & $\cdots$ & ... & $\cdots$ & $\cdots$ & $\ldots$ & ... & $\ldots$ & $\ldots$ \\
\hline Xenophthalmodes moebii, Richt...... & $x$ & $\ldots$ & $\cdots$ & $x$ & ... & $\ldots$ & ... & $\ldots$ & $\ldots$ \\
\hline Family Pinsotir & & & & & & & & & \\
\hline Ostracotheres tridacne, Rüpp. .... & $x$ & ... & $\ldots$ & ... & $\cdots$ & ... & $\cdots$ & $\cdots$ & $\ldots$ \\
\hline * & $x$ & $\ldots$ & $\cdots$ & 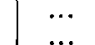 & 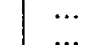 & $\cdots$ & $\cdots$ & $\cdots$ & \\
\hline Pinnotheres pectinicola, Bürg. ... & $\frac{x}{x}$ & .. & $\ldots$ & $\cdots$ & $\ldots$ & $\ldots$ & $\ldots$ & $\ldots$ & $\ldots$ \\
\hline- purp & $x$ & .. & $\ldots$ & $x$ & $x$ & $\ldots$ & $\ldots$ & ... & $\ldots$ \\
\hline - $-p e r$ & $x$ & . & $\cdots$ & & $\cdots$ & $\cdots$ & $\cdots$ & $\cdots$ & $\cdots$ \\
\hline - lutest & $\underset{x}{x}$ & $\cdots$ & $\cdots$ & ... & $\cdots$ & $\cdots$ & $\cdots$ & $\cdots$ & .. \\
\hline couttie & $\underset{x}{x}$ & .. & ... & $\cdots$ & ... $>\Rightarrow>>$ & ... & $\cdots$ & $\cdots$ & $\cdots$ \\
\hline - borrad & $\underset{x}{x}$ & & 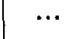 & 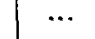 & & 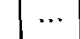 & $\ldots$ & t & $\cdots$ \\
\hline _L maindron & $x$ & & $\ldots$ & $\ldots$ & $\ldots$ & $\ldots$ & $\ldots$ & $\cdots$ & $\ldots$ \\
\hline * pilumnoides, I & $\stackrel{x}{x}$ & $\ldots$ & $\begin{array}{l}\cdots \\
\cdots\end{array}$ & $\begin{array}{l}\cdots \\
\ldots\end{array}$ & .. & $\cdots$ & $\cdots$ & $\cdots$ & $\cdots$ \\
\hline & & & & & & & & & \\
\hline
\end{tabular}

$\uparrow=$ Friphia levimana, Latr.; fide Rathbun, 1906, p. 865. 
Table I. (con.).

\begin{tabular}{|c|c|c|c|c|c|c|c|c|c|}
\hline & 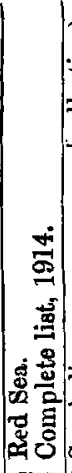 & 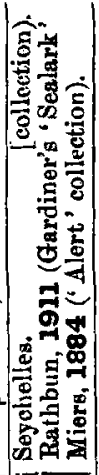 & 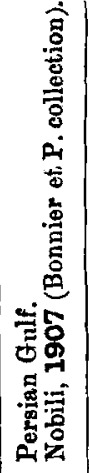 & 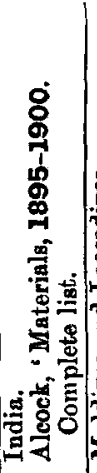 & 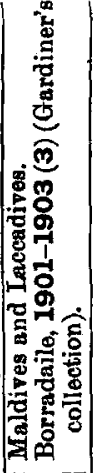 & 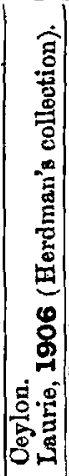 & 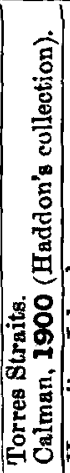 & 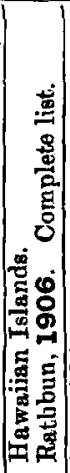 & 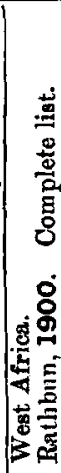 \\
\hline \multicolumn{10}{|l|}{ Family Ocrpodid } \\
\hline Ocypode cordimana, Desm................. & $x$ & $x$ & ... & $x$ & $x$ & $\cdots$ & $\ldots$ & $\cdots$ & ... \\
\hline — ceratophthalma (Pall.) ... & $x$ & $x$ & ... & $x$ & $x$ & $x$ & $x$ & $x$ & ... \\
\hline *__ jousseaumei, Nob. .............. & $x$ & .. & $\cdots$ & ... & ... & $\cdots$ & $\cdots$ & ... & ... \\
\hline${ }^{*}$ __ egyptiaca, Gerst. $\ldots \ldots \ldots \ldots \ldots \ldots . . . . .$. & $x$ & $\dddot{\ddot{ }}$ & $x$ & $\ldots$ & 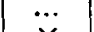 & \% & ... & $\cdots$ & $\cdots$ \\
\hline Ucat annulipes (Latr.) & $\underset{x}{x}$ & $x$ & $\underset{x}{x}$ & $x$ & $x$ & $\times$ & $\cdots$ & $\cdots$ & $\cdots$ \\
\hline$\{$ _ inversa (Hotim.).................. var. sindensis (Alc.). & $\mathrm{x}$ & $\begin{array}{l}\cdots \\
\ldots\end{array}$ & $\mathrm{x}$ & $\ddot{x}$ & $\cdots$ & $\cdots$ & $\cdots$ & $\cdots$ & $\cdots$ \\
\hline _tetragonon (Herbst) ........ & $\ddot{x}$ & $\cdots$ & $\ddot{x}$ & $\stackrel{x}{x}$ & $\cdots$ & $\cdots$ & $\ddot{x}$ & $\dddot{x}$ & $\cdots$ \\
\hline$\{$ - marionis (Desm.) ........... & $\ddot{x}$ & ... & $\cdots$ & $x$ & ... & $\cdots$ & ... & $\cdots$ & $\cdots$ \\
\hline -__, var. nitida, Duna..... & $x$ & ... & ... & $x$ & $\cdots$ & $\cdots$ & $\cdots$ & $\cdots$ & ... \\
\hline *Dotilla sulcata (Forsk.) .................... & $x$ & $\cdots$ & $\cdots$ & $x$ & $\cdots$ & $\cdots$ & $\cdots$ & $\cdots$ & $\cdots$ \\
\hline * Paraclistostoma leachii (Aud. et Sav.). & $x$ & $\cdots$ & ... & $\cdots$ & ‥ & $\cdots$ & $\cdots$ & $\cdots$ & $\cdots$ \\
\hline * Macrophthalmus verreauxi H. M.-Edw. & $x$ & $\cdots$ & $\cdots$ & $\mathrm{X}$ & $\times$ & $\cdots$ & $\cdots$ & $\cdots$ & $\cdots$ \\
\hline 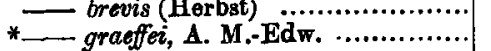 & $\begin{array}{l}x \\
x\end{array}$ & $\cdots$ & $\cdots$ & $\cdots$ & $\cdots$ & $\cdots$ & $\cdots$ & $\cdots$ & $\cdots$ \\
\hline *__ depressus, Rüpp...................... & $x$ & $\cdots$ & $x$ & $x$ & ... & $\cdots$ & ... & $\cdots$ & $\cdots$ \\
\hline $\begin{array}{r}\text { Euplax (Chonostoma) bosci (Aud. et } \\
\text { Sav.) }\end{array}$ & $x$ & $\cdots$ & $\cdots$ & $\cdots$ & $\cdots$ & $\cdots$ & $\cdots$ & $\cdots$ & $\cdots$ \\
\hline \multicolumn{10}{|l|}{ Family Hrumóomonde. } \\
\hline Elamena mathei (Desm.) …....... & $x$ & $\cdots$ & $\cdots$ & $\cdots$ & $\cdots$ & $\cdots$ & $\cdots$ & $\cdots$ & $\cdots$ \\
\hline \multicolumn{10}{|l|}{ Family Grapsidx. } \\
\hline f Grapsus grapsus (Linn.) .......... & $x$ & .. & $x$ & $x$ & ... & $\cdots$ & $\cdots$ & $\cdots$ & $x$ \\
\hline (- tenuiorustatus (Herbst) & . & $\cdots$ & ... & $Y$ & $\cdots$ & $\cdots$ & $\cdots$ & $\underset{x}{x}$ & $\cdots$ \\
\hline - strigosus (Herbst) & $x$ & $\ddot{x}$ & $\cdots$ & $x$ & 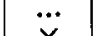 & $\cdots$ & $\cdots$ & $x$ & $\cdots$ \\
\hline Geograpsus grayi (H. M.-Edw.) …. & $x$ & $\begin{array}{l}x \\
x\end{array}$ & $\dddot{x}$ & $\begin{array}{l}x \\
x\end{array}$ & $x$ & $\ddot{x}$ & $\ddot{x}$ & $\ddot{x}$ & $\dddot{x}$ \\
\hline * Metopograpsus messor (Forsk.) .......... & $\underset{y}{x}$ & $\begin{array}{l}x \\
\ldots\end{array}$ & $x$ & $x$ & ... & $x$ & $x$ & $x$ & $x$ \\
\hline 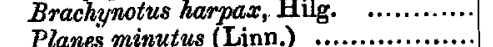 & $\begin{array}{l}x \\
x\end{array}$ & $\cdots$ & $\begin{array}{l}\cdots \\
\cdots\end{array}$ & $\begin{array}{l}\cdots \\
\ldots\end{array}$ & $\dddot{x}$ & $\cdots$ & $\begin{array}{l}\cdots \\
\cdots\end{array}$ & $\dddot{x}$ & $\dddot{x}$ \\
\hline Psetdograpsus erythreus, Kossm....... & $\hat{x}$ & ... & $\cdots$ & ... & $\ldots$ & $\cdots$ & $\cdots$ & ... & $\hat{\ldots}$ \\
\hline Cyclograpsus lophopus, Nob. .............. & $x$ & ... & $\cdots$ & $\ldots$ & $\ldots$ & $\ldots$ & $\ldots$ & $\ldots$ & $\ldots$ \\
\hline Sesarma (Sesarma) jousseaumei, Nob. . & $x$ & $\cdots$ & $\ldots$ & $\cdots$ & $\ldots$ & $\ldots$ & $\ldots$ & $\cdots$ & $\cdots$ \\
\hline ( Plagusia depressa (Herbst)................ & $\ldots$ & 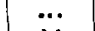 & $\cdots$ & $\ldots$ & $\cdots$ & $\cdots$ & $\cdots$ & $\cdots$ & $x$ \\
\hline- Par. tuberculuta, Lam. $\ddagger \ldots$ & $x$ & $\frac{x}{x}$ & $\cdots$ & $\begin{array}{l}x \\
x\end{array}$ & $\frac{x}{x}$ & $\ddot{x}$ & $\cdots$ & $\begin{array}{l}x \\
x\end{array}$ & $\ddot{x}$ \\
\hline Percnon § planzssimazm (Herbst) .......... & $x$ & $x$ & $\cdots$ & $x$ & $x$ & $x$ & $\cdots$ & $x$ & $x$ \\
\hline Family Palicida. & & & & & & & & & \\
\hline Palicus jukesii (Wh.) ..................... & $x$ & $x$ & $\cdots$ & $\underset{x}{x}$ & $x$ & $x$ & $x$ & $\cdots$ & $\cdots$ \\
\hline *__ whitei (Miers) $\quad \ldots . . . . . . . . . . . . . . . .$. & $x$ & $x$ & $\cdots$ & $x$ & *. & $\cdots$ & $x$ & $\cdots$ & $\cdots$ \\
\hline Family Hapalocarcinios. & & & & & & & & & \\
\hline Cryplochirus coralliodytes, Hell, ...... & $x$ & $\cdots$ & $\cdots$ & $\cdots$ & $x$ & $\cdots$ & $\cdots$ & $\cdots$ & $\cdots$ \\
\hline
\end{tabular}

+ Gelasimus, Iatr., $1817=$ Uca, Leach, 1814 ; see Rathbun, 1897, p. 154, and Steb., 1905 (1) p. 39.

+ For use of tuberculata, Lam., in preference to squamosa, Hbst., see Rathbun, 1906, p. 841 .

$\$$ Leiolophus, Miers, 1876=Percnon Gistel, 1848; see Rathbun, 1900. p. 281. 
The following is a summary of Table I. :-

TABLe II.

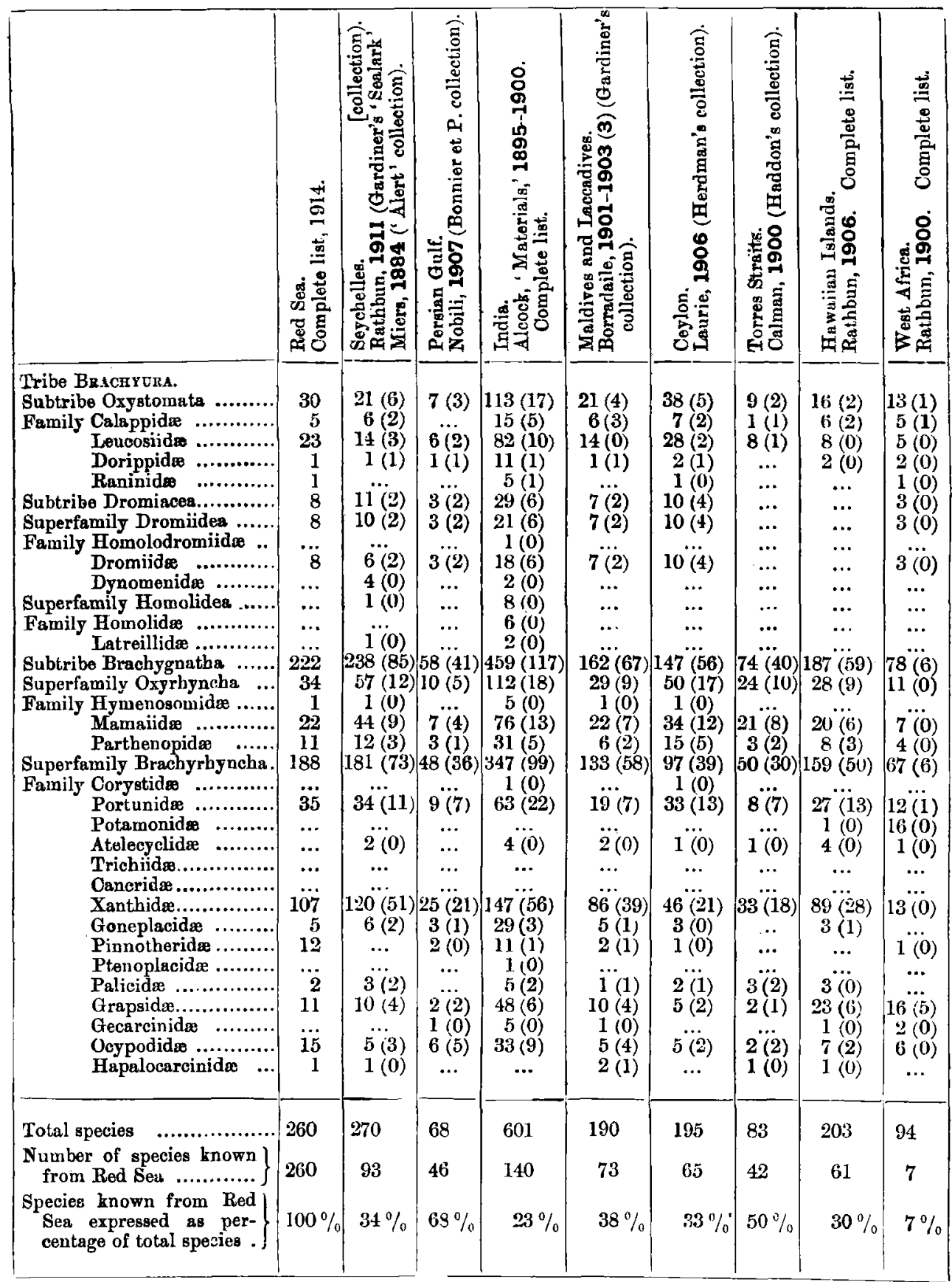


The first number in each column of the Table on p. 417 gives the number of species recorded from the source in question, the number in brackets gives the number of these which are known to occur also in the Red Sea.

Table II. is based upon Borradaile's classification (Borradaile, 1907, p. 477 et seq.). Elsewhere in this paper I have arranged the material in Nobili's order, to facilitate comparison with his ' Faune Carcinologique de la Mer Rouge.'

It will be seen that the affinity of the Red Sea crabs is strongest with those of the Persian Gulf, 68 per cent. of the species recorded from the latter locality having also been recorded from the Red Sea.

The homogeneity of the Indo-Pacific region is illustrated by the fact that in places so far apart as Seychelles and the Hawaiian Islands the percentage of crabs common to the Red Sea is very similar, approximately 33 per cent. in each case, that this per cent. occurs at Ceylon and a fairly similar one at the Maldives and Laccadives. India is below and Torres Straits distinetly above this average figure. In estimating the significance of these per cents. one notes that the Red Sea, having been very fuirly explored by a variety of collectors, is a good standard; but, on the other hand, one must bear in mind that other populations may have been sampled under different conditions, and it will be noted that the Torres Straits result, which appears somewhat anomalous, is associated with a comparatively short list. If allowance were made for these possible sources of error, the similarity might be even more striking. But taking the figures at face value, certain points stand out clearly : (1) the comparative similarity of the crabs over the whole IndoPacific area ; (2) the almost entire lack of specific resemblance between the crabs of the Red Sea and those of West Africa ; (3) omitting Persian Gulf as being in the immediate vicinity of the Red Sea, the Indo-Pacific figures suggest that one may prophesy with a probable error of \pm 5 or 6 that 35 is the most likely percentage of species common to the Red Sea which will be found in a collection of say 200 species of crabs from any hitherto insufficiently investigated portion of the Indo-Pacific Region; the odds are about 20 to 1 against the error in such a prophecy being greater than \pm 15 . One may also prophesy with a probable error of \pm 2 or 3 that 35 is the most likely average percentage of species common to the Red Sea which will be found on examining six further samples of Indo-Pacific crabs of similar numbers to those which I have considered; the odds are about 20 to 1 against the probable error of such a prophecy being greater than \pm 7 . The number of samples I have considered is of course small, and the attempt to give numerical precision to the degree of homogeneity of the Brachyuran fauna of the coral zone presents certain intricacies not considered here, but the figures I give are, I believe, not without some value and may form the basis of further investigation upon similar lines.

The West African forms recorded from the Red Sea comprise only 
Calappa gallus (Herbst), Grapsus grapsus (Linn.), Planes minutus (Linn.), Percnon planissimum (Herbst), Metopograpsus messor (Forsk.), Plagusia depressa (Herbst), and Thalamita integra, Dana, of which the first four are of little or no account, owing to their exceptionally wide distribution, and the last two are varietally distinct.

To save frequent repetition, I give here a list of stations from which the present collection was made, the latitudes of which $I$ have estimated approximately.

Crossland's maps, published in the present volume of this Journal, pages 6 and 15, and Plates 28, 29, and 30, should be consulted.

I. Suez. Lat. $28^{\circ} \mathrm{N}$.

A. Suez mud-flats.

B. Suez flats and docks. Dec. 1904.

C. Suez mud-flats; washings of weed and sponge. The washings included an abundance of small and very large Amphipoda, some Isopoda, not many Brachyura, only two or three Macrura, and very few small Polychæta, also numerous Foraminifera.

D. Suez docks. From beneath a floating stage which had been in the docks for several years. 26 Dec., 1904.

E. Between Suez and Port Tewfik. Amongst stones of the embankment, bordering mud-flats, near high-tide level.

F. As E plus Decapoda washed out of sponge and weed.

G. Suez Bay. Trawled in 5 fathoms, from mud bottom.

H. Suez Bay. Trawled in 5 fathoms, from mud bottom, among sponges.

I. Suez Bay. From a red sponge taken from mud bottom in 10 fathoms.

J. Suez. From among coral.

K. Suez. Washed by fresh water from two coral colonies.

L. Etuleh coral shoals, Suez Bay. Large areas covered by Chama and an Ostreid. In 1-3 fathoms.

II. Mersa Wadi Lehama, Egyptian coast. Lat. $24^{\circ} 45^{\prime} \mathrm{N}$.

III. Cape Elba, the northern frontier of Sudan coast. Lat. $22^{\circ} \mathrm{N}$.

IV. Mersa Abu Hamama. Lat. $21^{\circ} 30^{\prime} \mathrm{N}$.

V. Khor Dongonab. Lat. $21^{\circ} 11^{\prime} \mathrm{N}$. to lat. $20^{\circ} 50^{\prime} \mathrm{N}$.

A. Washed from nullipore and branched coral from the reef off Beacon Island. Lat. $20^{\circ} 55^{\prime} \mathrm{N}$. 26 April, 1905. There were many Polychæta and Decapoda, comparatively few Amphipoda, and some Echinodermata in the same washings.

B. Just west of Beacon Island. Lat. $20^{\circ} 55^{\prime} \mathrm{N}$. Washed from nullipore dredged in 3-5 fathoms, 26 April, 1905. In the same washings were many Decapoda and Polychæta, especially the 


\begin{tabular}{|c|c|}
\hline 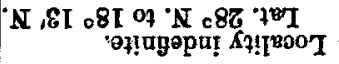 & $\vdots \vdots \vdots \vdots \vdots \vdots \vdots \vdots \vdots \vdots \vdots: \vdots \vdots \vdots \vdots \vdots \vdots \vdots \vdots \vdots \vdots \vdots \vdots \vdots \times$ \\
\hline 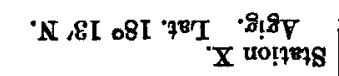 & 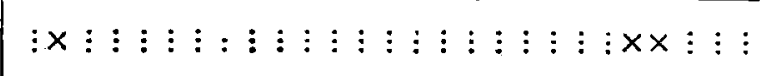 \\
\hline 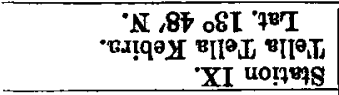 & $\vdots \vdots \vdots \vdots \vdots \vdots \vdots \vdots \vdots \vdots \vdots \times \quad \vdots \vdots \vdots \vdots \vdots \vdots \vdots \vdots \vdots \vdots \vdots \vdots \vdots \vdots \vdots:$ \\
\hline 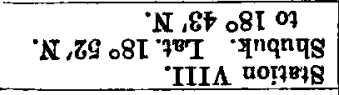 & $\vdots \vdots \vdots \times \quad \vdots \times \times \quad \vdots \quad \vdots \vdots \vdots \vdots \vdots \times \times \times \quad \vdots \times \quad \vdots \quad \vdots \vdots \vdots \vdots \vdots \vdots \vdots$ \\
\hline 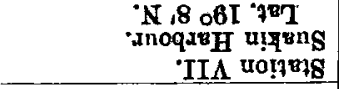 & $\vdots \vdots \vdots \times \quad \vdots \vdots \vdots \vdots \vdots \vdots \vdots \vdots \vdots \times \quad \vdots \quad \vdots \vdots \vdots \vdots \times \vdots \vdots \vdots \times \vdots \vdots$ \\
\hline 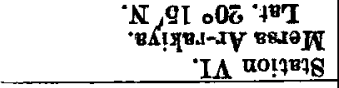 & 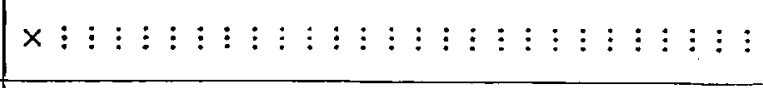 \\
\hline 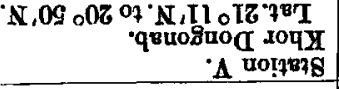 & $\vdots \vdots \vdots \vdots \times \vdots \vdots \vdots \times \times \vdots \times \times \quad \vdots \vdots \vdots \vdots \vdots \vdots \vdots \vdots \vdots \times \vdots \vdots \vdots \vdots$ \\
\hline 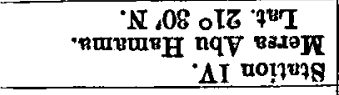 & 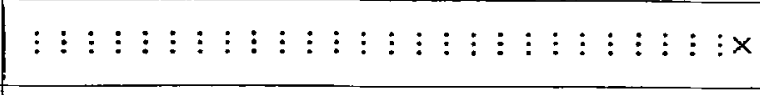 \\
\hline 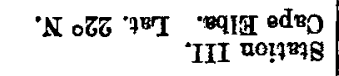 & $\vdots \vdots \vdots \vdots \vdots \vdots \vdots \vdots \vdots \vdots \vdots \vdots \vdots \vdots$ \\
\hline 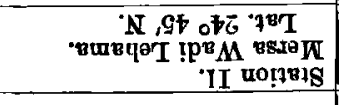 & $\vdots \vdots \vdots \vdots \times \times \vdots \vdots: \vdots \vdots \vdots \vdots \vdots \vdots$ \\
\hline 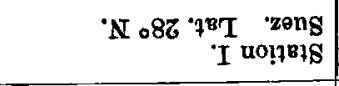 & 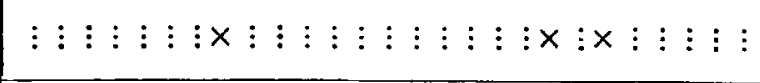 \\
\hline & 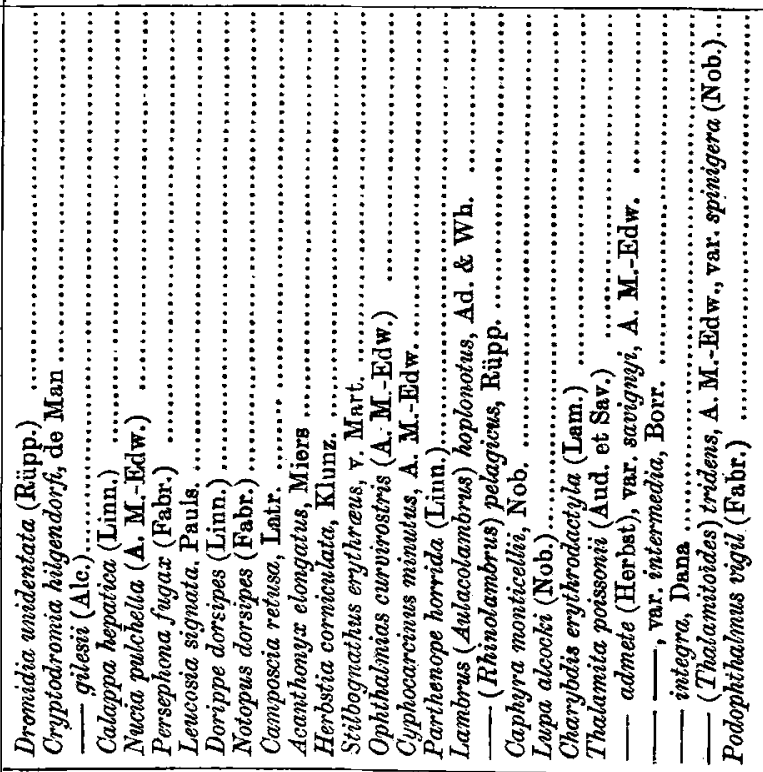 \\
\hline & - \\
\hline
\end{tabular}


$\vdots \times \vdots \times \vdots \vdots \times \vdots \times \vdots \times \vdots \vdots \times \vdots \times \vdots \vdots: \times \vdots \vdots \times \times \leq \times \times \vdots \vdots \vdots \vdots \times \times \vdots \vdots \vdots \vdots \vdots \vdots \vdots \vdots$

$\vdots \vdots \vdots \vdots \vdots \vdots \vdots \vdots \vdots \vdots \vdots \vdots \vdots \vdots \vdots \vdots \vdots \vdots \vdots \times \leq \vdots \times \times \times \quad \vdots \vdots \vdots \vdots \vdots \vdots \vdots \vdots \vdots \vdots \vdots \vdots \vdots \vdots \vdots$

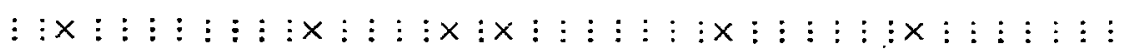

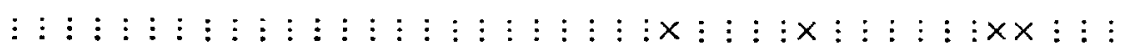

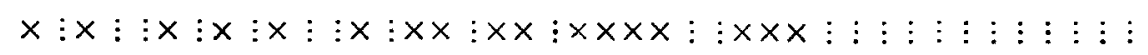

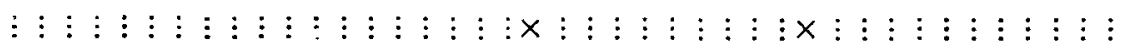

$\vdots \vdots \vdots \times \times \vdots \vdots \times \vdots \vdots \times \vdots \times: \times \times \times \vdots \vdots \times \times \vdots \vdots \times \vdots \vdots \times \leq \times \leq \times \leq \vdots \vdots \vdots \vdots \vdots \vdots \vdots \vdots$

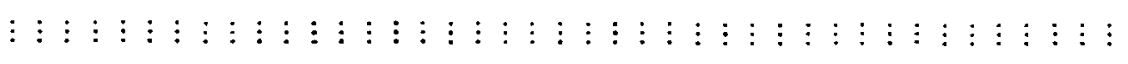

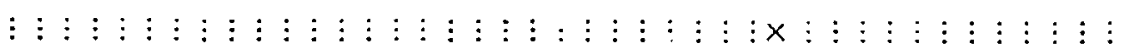

$\vdots \vdots \vdots \vdots \vdots \vdots \vdots \vdots \vdots \vdots \vdots \vdots \vdots \vdots \vdots \vdots \vdots \vdots \vdots \vdots \vdots \vdots \vdots \vdots \vdots \vdots \vdots \vdots \vdots \vdots \vdots \vdots \vdots \vdots \vdots \vdots \vdots) \quad \vdots$

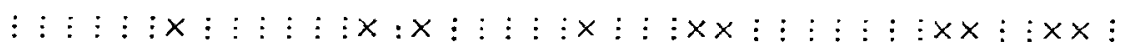

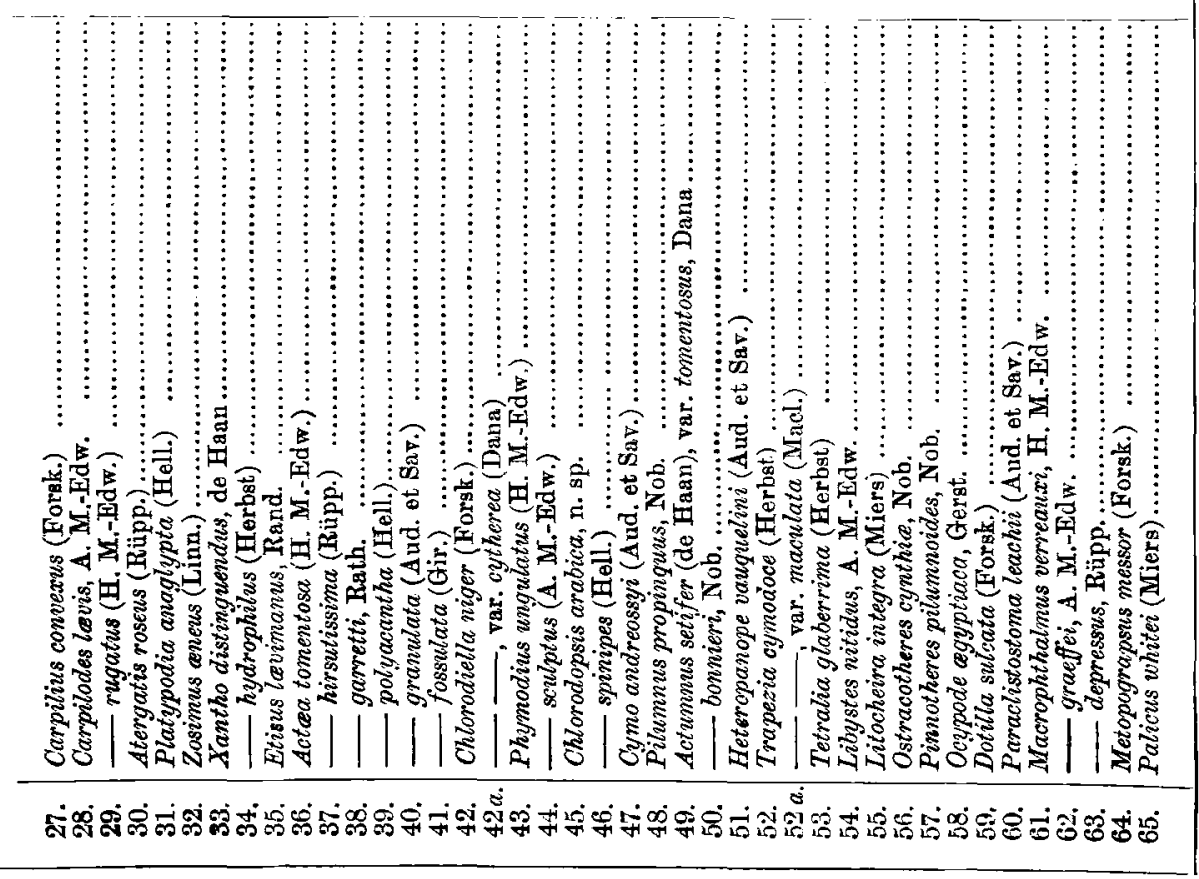


latter, a few Amphipoda, a few Echinodermata, and some Foraminifera.

C. Engineer Island. Lat. $20^{\circ} 50^{\prime} \mathrm{N}$. Washed from old coral and weed obtained from Reef Flat. The washings were composed mostly of Polychreta (Eunicidæ, Nereidæe, etc.) and Decapoda (mostly small Brachyura), unly two or three Amphipoda, no mud.

D. Engineer Island. Lat. $20^{\circ} 50^{\prime}$ N. Washed from a small bucketful of weed and coral dredged in 3 fathoms of water. The washings were very rich in everything.

E. Khor Dongonab. Among coral on reef.

F. Khor Dongonab.

G. Islet group, Khor Dongonab. From mud and coarse sand in 11 fathoms of water. This islet group is probably the same as "Four Islet Shoal" of Crossland's map (loc. cit. p. 15), which would place it just north of lat. $21^{\circ} \mathrm{N}$.

VI. Mersa Ar-rakiya. Among coral in 1 fathom of water. Lat. $20^{\circ} 15^{\prime} \mathrm{N}$. VII. Suakin Harbour. Lat. $19^{\circ} 8^{\prime} \mathrm{N}$.
A. Suakin Harbour.
B. Suakin Harbour. 26 Jan., 1905.
C. Suakin Harbour. Purchased from a fisherman.
D. Suakin Harbour. From coral, 1905.
E. Suakin Hurbour, near Customs' landing. From muddy bottom, in 5 fathoms of water.

VIII. Shubuk. Lat. $18^{\circ} 52^{\prime} \mathrm{N}$. to $18^{\circ} 43^{\prime} \mathrm{N}$.

A. Mersa Makdah in Shab-ul-Shubuk. 16 Feb., 1905.

B. Passage south of Mersa Makdah in Shab-ul-Shubuk. From a colony of coarse Campanularian Hydroids, overgrown with Alga, brought up by a diver. In the washings there were also great quantities of Amphipoda, but very little else, a few Polychæta, and a Planarian ; the mud, however, is rich in Foraminifera, the lighter mud contains very minute Amphipoda.

C. We Shubuk, north-east corner. 16 Feb., 1905.

D. We Shubuk, south-east corner. 16 Feb., 1905.

E. "Dredge washings, 17 Feb., 1905." No locality is given, but records were made by Crossland on the previous day from northeast corner of We Shubuk, south-east corner of We Shubuk, and Mersa Mukdah in Shab-ul-Shubuk.

IX. Tella Tella Kebira, a small group of islands in the northern part of Suakin Archipelago. Lat. $18^{\circ} 48^{\prime} \mathrm{N}$.

A. Tella Tella Kebira. Washed from the half-loose coral fragments and nullipore which compose the edge of the Southern Reef. The washings were rich generally, minute Brachyura and Polychæta very numerous. 3 March, 1905. 
B. Tella Tella Kebira. From sand. The fauna includes the common shore hermit-crabs, which live above ligh-tide level, and the yellow land-crab, so abundant on the sand cays at Khor Dongonab and elsewhere, wherever there is sand for its burrows.

X. Agig. Lat. $18^{\circ} 13^{\prime} \mathrm{N}$. From among coral in $4 \frac{1}{2}$ fathoms of water. Agig is close to the southern frontier of the Sudan.

The distribution of the species in the present collection among the above Stations is set out in Table III. (pp. 420-421).

As regards literatme, I have referred in every case to some good description-in Alcock's 'Materials,' whenever possible. I have included in the synonymies all references to Nobili, 1906, and Klunzinger, 1906, the two most recent accounts of Red Sea Brachyura. Most references of earlier date will be fonna in the works just named, but I have added a few others. The more recent literature on Indo-Pacific Brachyura has been referred to as has appeared desirable. Useful lists of general carcinological literature are given in Alcock, 1901, Klumzinger, 1906, and Ihle,1913. Important discussions on nomenclature will be found in Rathbun, 1897, and in Stebbing's 'South African Crustacea,' in which latter also are notes on classification and very useful synonymies. Borradaile 1902 (1) contains suggestive remarks on varieties.

\section{Literature cited.}

Alcock, A., 1895.-Materials for a Carcinological Fauna of India : No. 1. The Brachyura Oxyrhyncha. Journ. As. Soc. Bengal, vol. lxiv. pt. ii., 1895.

__ 1896.-Ibid.: No. 2. The Brachyura Oxystona. Ibid. rol. lxv. pt. 2, 1896.

1898.-Ibid.: No. 3. The Brachyura Cyclometopa.... Xanthidæ. Thid. vol. Ixrii. pt. 2, 1898.

1899 (1)._Ibid.: No. 4. The Brachyura Cyclometopa.... Portunide, Cancridæ, and Corystidæ. Ibid. vol. Ixviii. pt. 2, 1899.

1899 (2)._- Ibid.: No. 5. The Brachyura Primigenia or Dromiacea. Ibid. vol. lnviii. pt. 2, 1899.

1899 (3).--Illustrations of the Zoulogy of the .... 'Investigator,' Crustacea, Purt 7. Calcutta, 1899.

1900.-Materials, etc. : No. 6. The Brachyura Catometopa or Grapsoidea. Journ. As. Soc. Bengal, vol. lxix. pt. 2, 1900.

- 1901.-Catalogue of the Indian Decapod Crustacea in the Collection of the Indian Museum, Part I. Brachyura, fasc. i. Introduction and Dromides .... Calcutta, 1901.

— 1902.-Illustrations of the Zoology of the ... 'Investigator;' Crustacea : Part 10. Calcutta, 1902.

Audourn, V., 1826.-Explication sommaire des Planches dont les dessins ont été fournis par M. J. C. Savigny. Descrip. de l'Egypte, Histoire Naturelle, Texte, Tom. 1, pt. 4, Crustacés, 1826. [See SavignY.] 
Borradatur, L. A., 1901.-Land Crustaceans. Gardiner's Fauna and Geogr. of Maldive and Laccadire Arch., vol. i. pt. 1, 1901.

1902 (1).-Marine Crustaceans : I. Varieties, II. Portunidæ. Ibid. rol. i. pt. 2, 1902. 1902 (2),-Ibid. : III. Xanthidre, etc. Ibid. vol. i. pt. 3, 1902.

1903 (1).-Ibid. : IV. Olassif. Crabs, V. Catometope families, VI. Oxystomata. Ibid. vol. i. pt. 4, 1903.

1903 (2).-Ibid.: IX. Dromiacea. Ibid. vol. ii. pt. 1, 1903.

1903 (3).-Ibid. : X. Oxyrhyncha, XI. Classif. Reptant Decapods. Ibill. vol. ii. pt. 2, 1903.

1903 (4).-On the Genera of Dromiidx. Ann. Mag. Nat. Hist. (7) vol, xi., 1903.

1907.-On the Classification of the Decapod Crustaceans. Ann. Mag. Nat. Hist. (7) vol. xix., 1907.

Calman, W. T., 1900.-On a Collection of Brachyura from Torres Straits. Trans. Linn. Soc. London (2), Zool, vol, viii., 1900.

1909.-On Decapod Crustacea from Christmas Island collected by Dr. C. W. Andrews. Proc. Zool. Soc. London, 1909.

1913.-Note on the Brachyuran Genera Micippoides and Hyastenus. Anu. Mag. Nat. Hist. (8) vol. xi., 1913.

Dana, J. D., 1852.-United States Exploring Expedition: Vol. xiii. Crustacen, pt. 1, Podophthalmata. Philadelphia, 1852 ; Atlas, 1855.

Fabricius, J. C., 1798.-Supplementum Entomologiæ Systematicæ. Copenhagen, 1798.

HAAN, W. DF, 1841.-Crustacea (1839-1849), Pt.5. P. F. de Siebold's 'Fauna Japonica,' Leyden.

Hezler, C., 1861.-Beiträge zur Crustaceen-Fauna des rothen Meeres. SB. Akad. Wien, vol. sliii., 1861.

Henderson, J. R., 1893 -A Contribution to Indian Carcinology. Trans. Linn. Soc. London (2), Zool., vol. v., 1893.

Inte, J. E. W., 1913.-Jie Decałoda Brachyura der Siboga-Expedition: I. Dromiacea. Leiden, Nov. 1913.

Kinahan, J. R., 1856.-Remarks on the Habits and Distribution of Marine Crustacea on the eastern shores of Port Philip, Victoria, A tistralia. Journ. Roy. Dub. Soc., October 1856. [Bound in vol. i., 1856-57 (1858).]

Kuonzrngke, C. B., 1906.-Die Spitz- und Spitzmundkrabben des Roten Meeres. Stuttgart, 1906.

Kossmann, R., 1877.-Malacostraca Brachyura. Zoologische Ergebnisse einer . . . Reise in die Küstengebiete des Rothen Meeres, Erste Hälfte, Leipzig, 1877. 1880.-Malacostraca Anomura. Ibid., Zweite Hälfte, Leipzig, 1880.

Ladirie, R. D., 1906.-Report on the Brachyura collected by Professor Herdman at Ceylon in 1902. Herdman's Rept. Ceylon Pearl Oyster Fisheries, purt 5, 1906.

Mav, J. G. DN, 1888.-Report on the Podophthalmous Crustacea of the Mergui Archipelago collected by Dr. John Anderson. Journ. Linn. Soc., Zool., vol, xxii., 1888.

Martins, E. von, 1866.-Verzeichniss der von G. Schwoinfurth 1864 am Roten Meere gesammelten zoologischen Gerganstände. Yerh. zool. bot. Ges. Wien, rol. xvi., 1866.

Mreas, E. J., 1877.-On a Collection of Crustacea chiefly from South America. Proc.EZZool. Soc. London, 1877.

- 1879.-Description of new or little-known species of Maioid Crustacea (Oxyrhyncha) in Collection of British Museum. Ann. Mrg. Nat. Hist. (5) vol. iv., 1879.

— 1880.-On Crustacea from the Malaysian Region. Ann. Mag. Nat. Hist. (5) vol. v., 1880. 
Murns, E. J., 1882.-On the Species of Ocypoda in the Collection of the British Museum. Ann. Mag. Nat. Hist. (5) vol, x., 1882.

- 1884.-Crustacea. Report on the Zoological Collections . . . H.M.S. 'Alert.' London, 1884.

— 1886.-Report on the Brachyura collected by H.M.S. 'Challenger.' Rept. Sci. Results Voyage 'Challenger,' Zoology, vol. xvii., 1886.

Mirne-Edwards, A., 1865.-Etudes zoologiques sur les Crustacés récents de la famille des Cancériens. Nouv. Arch. Mus. tom. i., 1865.

—_ 1868.-Descriptions de quelques Crustacés nouveaux provenant des Voyages à Zanzibar et à Madagascar. Nouv. Arch. Mus. tom. iv., 1868.

-_ 1869.-Descriptions de quelques Crustacés nouveaux de la Famille des Portuniens. Nouv. Arch. Mus. tom. v., 1869.

___ 1873 (1)._-Recherches sur la Faune Carcinologique de la Nouvelle-Calédonie. Nouv. Arch. Mus. tom. ix., 1873.

- 1873 (2).--Description de quelques Crustacés du Musée de C. Godeffroy. Jour. Mus. Godeffi., Hamburg, Band i. Heft iv., 1873.

Mulne-Edwards, H., 1834.-Histoire naturelle des Crustacés, vol. i., 1834.

_- Cuv.-Les Crustacés. La Règne Animal par Georges Cuvier, Paris, 1836-1849. [Third or Disciples Edition.]

__ 1853.-Observations sur la Classification des Crustacés. Ann. Sci. Nat. (3) vol. xx., 1853.

Nobıcr, G., 1901.-Decapodi e Stomatopodi Eritrei del Museo Zoologico dell' Università di Napoli. Ann. Mus. Zool. Univ. Napoli (Nuova Serie), vol. i. no. 3, 30 Sept. 1901.

-_ 1906.-Faune Carcinologique de la Mer Rouge, Decapodes et Stomatopodes. Anu. Sci. Nat. Zool. (9) vol. iv., 1906.

_ 1907.-Mission J. Bonnier et Ch. Pérey (Golfe Persique, 1901), Crustacés Decapodes et Stomatopode . Bull. Sci. Fr. Belg. vol. xl., 1906.

Parison, O., 1875.--Researches on Red Sea Crustacea (in Russian), 1875.

Rand.1LI, J. W., 1840-Cat. Crust. W. Coast N. America and Sandwich Isds. Journ. Acad. Nat. Sci. Philadelphia, vol. viii., pt. 1, 1839 (1840). [Title-page of pt. 1 bears publisher's date 1839 but the part includes a paper read 7 Jan. 1840.]

Rathbun, M. J., 1897.-A Revision of the Nomenclature of the Brachyura. Proc. Biol. Soc. Washington, vol. xi., 1897.

— 1900.-The Decapod Crustaceans of West Africa. Proc. U.S. Nat. Mus. vol. xxii., Washington, 1900.

1902.-Japanese Stalk-eyed Crustacen. Ibid., vol. xxvi,, 1902.

- 1904. - Sone Changes in Crustacean Nomenclature. Proc. Biol. Soc. Washington, vul. xvii., 27 Dec. 1904. [Bound vol. published 1905.]

- 1906.-The Brachyura and Macrura of the Hawaiian Islands (issued 27th Jan., 1906). Bull. U.S. Fish Commission, vol. xxiii. for 1903, part iii., Washington, 1906.

- 1911.-Marine Brachyura: Report No. 11 of Gardiner's "Percy Sladen Trust Expedition to the Indian Ocean in 1905." Trans. Linn. Soc. London (2), Zool., vol. xiv., 1911.

Savigny, J. C., 1826.-Plates of Crustacea, 1-13. Description de l'Égypte, Histoire Naturelle, Planches, tom. ii., 1826. [See Audour.]

Stmberng, T. R. R., 1902.-South African Crustacea, pt. ii., Marine Invest. Dept. Agriculture, Cape of Good Hope, Cape T'own, 1902.

_- 1905 (1).-Ibid., pt. iii., Marine Invest. Ibid., 20 Feb. 1905. [Bound in vol. iv., 1908.]

__ 1908.-Ibid., pt. iv., Marine Invest. Ann. S. Afr. Mus. vol. vi., pt. 1, 2 Apl. 1908. 
Stebbing, T. R. R., 1910.-Ibid., pt. v., Gen. Catalogue, Marine Invest. Ibid., vol. vi., pt. 4, 15 Dec. 1910.

1905 (2).--Zuological Nomenclature. Journ. Linn. Soc., Zool., vol. xxix., 1905.

Stimpson, W., 1907.-Report on the Crustacen (Brachyura and Anomura) collected by the

North Pacific Exploring Expedition, 1853-1856. Smithson. Collect. rol. xlix., Washington, 1907. [Edited by M. J. Rathbun.]

\section{Subtribe DROMIACEA.}

\section{Family DROMIID王.}

Genus Dromida, Stimpson, 1859, emend. Borradaile, 1903.

1. Dromidia unidentata (Rïppell, 1830). See Alcock, 1899 (2), p. 139.

Dromia unidentata, Alcock, loc. cit.

Dromidia unidentata, Nobili, 1906, p. 145.

Dronidia unidentata, Ihle, 1913, p. 31.

Locality. Station VI., $1 \delta[1] *$.

Remarks. C.l. $\nmid 22 \mathrm{~mm} .$, C.b. $22 \mathrm{~mm} .$, 1st W.L. $34 \mathrm{~mm} ., 2$, 2 W.L. $32 \mathrm{~mm}$, 3rd W.L. $20.5 \mathrm{~mm}$, 4 th W.L. $25 \mathrm{~mm}$.

The specimen is of the same order of size as those described by Alcock, but his statement regarding the relative lengths of the walking-legs is that " the fourth (last) pair of leggs are not so very much shorter than either of the first two pairs and are very much longer than the third pair."

$$
\text { Genus Cryprodromia, Stimpson, } 1859 .
$$

2. Cryptodromia hilgendorfi, de Man, 1887. See Alcock, 1899 (2), p. 145. Dromia (Cryptodromia) Hilgendorf, Alcock, loc. eit. Cryptodromia Hilgendorfi, Nobili, 1906, p. 146. Cryptodromia hilgendorfi, Ihle, 1913, p. 45.

Locality. Station X., 1 \% ovig. [2].

Remarks. C.1. $12.5 \mathrm{~mm}$., C.b. $12.5 \mathrm{~mm}$. Alcock describes the carapace as being longer than broad in two specimens-a male and a female-from the Persian Gulf. In the present specimen this is not the case, nor is it so in an example from Ceylon (Laurie, 1906, p. 352), where C.b. $\div$ C.l. $=1.03$. The two lateral teeth of the front are less prominent in the present example than in the one from Ceylon just named.

My specimens agree with those of Nobili in having the outer orbital angle more prominent and sharper than represented in de Man's figure; Alcock says that this region is not dentiform, it is in the present specimen at least sub-dentiform.

* The collection is housed in the Museum of the Dept. of Zoulogy, University of Liverpool.

$\dagger$ Abbreviations are those nsed by Laurie, 1906, p. 350. 
3. Cryptodromia gilesil (Alcock, 1899). See Alcock, 1899 (2), p. 146.

Dromia (Cryptodromia) Gilesii, Aleock, loc. cit.

Cryptodromia Gilesii, Alcock, 1901, p. 54, pl. 3. fig. 13.

P Nec Cryptodromia granulata, Nobili, 1906, p. 147, pl. 9. fig. 5.

Locality. Station II., 1 o apparently adult [3].

Remarks. The specimen agrees with Alcock's description. C.l., including frontal teeth, $9 \cdot 5 \mathrm{~mm}$., C.b. $10 \mathrm{~mm}$.

The species is new to the Red Sea, it has hitherto been recorded only from the Malabar coast in 29 fathoms by Alcock.

It has in many of its characters a suspicious resemblance to Cryptodromia granulata, the Epidromia granulata of Kossmann (Kossmann, 1880, p. 69 ; and Nobili, loc. cit.). The two species are evidently, as pointed out by Nobili, very closely related, but, though it is possible that they may come later to be regarded as one, the published evidence yet available does not in my view warrant one in uniting them. It may be that there is little difference beyond the form of the front, but this is markedly different. In Alcock's species the lateral frontal teeth are much longer and the supraorbital border more oblique. I have not had the opportunity of examining the type-specimens.

\section{Subtribe OXYSTOMATA. \\ Family CALAPPID E. \\ Genus Calappa, Fabricius, 1798.}

4. Calappa hepatica (Linnuus, 1764). See Alcock, 1896, p. 142.

Calappa hepatica, Nobili, 1906, p. 148.

Calappa hepatica, Klunzinger, 1906, p. 60.

Calappa tuberculata, Stimpson, 1907, p. 165.

Localities. Station VII. E, $2 \Varangle[4,5]$; Station VIII. A, 2 \& $[6,7]$; Station VIII. C, 1 o [8], 1 \& [9].

Remarks.

\begin{tabular}{|c|c|c|c|c|c|c|}
\hline C.1. & $\begin{array}{c}q 6 \text { juv. } \\
10.5\end{array}$ & $\begin{array}{l}\text { ㅇ } 9 . \\
15 \cdot 0\end{array}$ & $\begin{array}{c}\text { ㅇ } 7 \text { ovig. } \\
15 \cdot 0\end{array}$ & $\begin{array}{c}\text { o } 8 \text { juv. } \\
11 \cdot 5\end{array}$ & $\begin{array}{c}04 . \\
21.5\end{array}$ & $\begin{array}{c}05 . \\
22 \cdot 0 \mathrm{~mm} .\end{array}$ \\
\hline $\mathrm{C.b}_{1} \ldots$ & $11 \cdot 0$ & $16 \cdot 0$ & $16 \cdot 0$ & $12 \cdot 2$ & $24 \cdot 0$ & $25.0 \mathrm{~mm}$. \\
\hline C.b.2. $\ldots \ldots \ldots$ & 15.0 & $21 \cdot 0$ & $20 \cdot 5$ & 16.5 & $32 \cdot 5$ & $34.0 \mathrm{~mm}$. \\
\hline C.b. $._{1} \div$ C.l. & .95 & .94 & .94 & .94 & 89 & .88 \\
\hline $\mathrm{C}_{.} \mathrm{b}_{2} \div$ C.l. & $\cdot 70$ & $\cdot 71$ & 73 & $\cdot 70$ & 66 & $\cdot 65$ \\
\hline
\end{tabular}

C.b..$_{1}$ is measured immediately in front of the clypeiform expansions; C.b.g is measured across the clypeiform expansions, from tip to tip of the fourth pair of teeth.

The specimens agree very well with Alcock's description. The emargination of the front is in all the specimens but slightly evident. The measurements given above indicate growth-change in the $\delta$ in regard to the ratio C.b. $\div$ C.l. 


\section{Family LEUCOSIID $\not E$.}

Genus Nucia, Dana, 1852.

5. Nucia pulohella (A. Milne-Edwards, 1873). See Nobili, 1906, p. 163. Locality. Station V. A, 1 \% [10].

Remarks. C.l. $3 \mathrm{~mm}$., C.b. $3.5 \mathrm{~mm}$., frontal b. $1.1 \mathrm{~mm}$. Only two other examples of the species have been recorded. The present specimen is of the same size as that of Nobili from the Red Sea; A. Milne-Edwards's typespecimen from the Fiji Islands has C.1. $5.5 \mathrm{~mm}$. and C.b. $6 \mathrm{~mm}$.

Genus Persephona, Leach, 1817.

Includes Myra, Leach, 1817 ; teste Rathbun.

6. Persephona fugax (Fabricius, 1798). See Alcock, 1896, pp. 202 and 204.

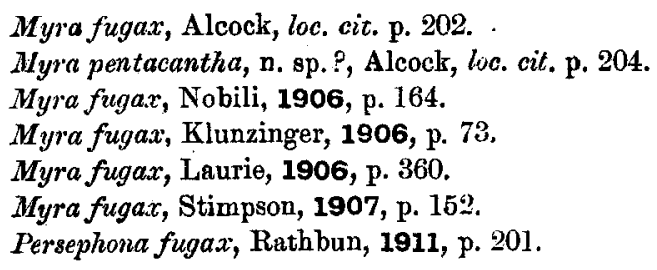

Locality. Station VIII. A, 1 q juv. [11].

Remarks. C.l. including posterior spine, $11 \mathrm{~mm}$; Ch.l. 19; mm.; C.1. $\div$ Ch.l. $=1 \cdot 73$. The specimen appears to be a late pentacantha stage, the spine on either postero-lateral margin above the last pair of legs is slightly indicated.

I agree with Nobili in believing that Persephona pentarantha, very doubtfully created by Alcock, is in reality the young stage of Persephona fugax.

\section{Genus Leucosia, Fubricius, 1798.}

The adoption of Leucosides, Rathbun, 1897, as a name for this genus depends upon one's acceptance, with Rathbun, of Latreille's examples of genera in 1810 as specifications of type (Rathbun, 1897, p. 160). I agreo with Stebbing (Stebbing, 1902, p. 11, and 1908, p. 11) in not so accepting them.

7. Leucosia signata, Paulson, 1875. See Klunzinger, 1906, p. 69. Letucosia signata, Nobili, 1906, pp. 163 and 344.

Leucosia fuscomaculata, Klunzinger, loc. cit.

Localities. Station II., $1 \delta^{\star}[12]$; Station VIII. A, 8 \& [13-20], 10 व [21-30]; Station VIII. D, 1 \& [31]. 
Remarks. The specimens comprise $5 \delta$ juv., 6 odult, 6 o juv., and 3 o adult, non-ovig.

The adult females have a rounded posterior border; in all the adult males the angles of the posterior border, though rounded, are a little prominent; in all the young of both sexes the posterior border is straight with somewhat prominent angles.

The measurements given below show that the size of the adult specimen is of the same order as given by Nobili :-

\begin{tabular}{|c|c|c|c|c|}
\hline C.1........ & $\begin{array}{c}\text { q adult. } \\
19 \cdot 0\end{array}$ & $\begin{array}{c}\text { Q adult. } \\
22 \cdot 5\end{array}$ & $\begin{array}{l}\text { of adult. } \\
19 \cdot 5\end{array}$ & $\begin{array}{l}\text { o adult. } \\
21.0 \mathrm{~mm}\end{array}$ \\
\hline C.b. $\quad \ldots \ldots$ & $16 \cdot 0$ & $19 \cdot 0$ & 16.5 & $17.5 \mathrm{~mm}$ \\
\hline C.l. $\div$ C.b..... & .84 & $\cdot 84$ & 84 & $\cdot 83$ \\
\hline
\end{tabular}

In adult $\delta 30$ (C.l. $19 \mathrm{~mm}$.), the granules on the postero-lateral border of the carapace are not continued further back than the first pair of walking legs, above which they fade away. The specimen has the $M$ well marked on the carapace and is clearly for all other reasons also to be placed in this species.

\section{Family DORIPPID无.}

Genus Dorippe, Fabricius, 1798.

8. Dorippe dorsipes (Limenes, 1764). See Alcock, 1896, p. 277.

Dorippe dorsipes, Nobili, 1906, p. 172.

Dorippe dorsipes, Nobili, 1907, p. 95.

Dorippe dorsipes, Laurie, 1906, p. $\$ 67$.

Dorippe quadridens, Stimpson, 1907, p. 167.

Locality. Station I. H, 1 i immature [32].

Remarks. C.l. $8 \cdot 25 \mathrm{~mm}$.

The spine at the outer angle of the orbit reaches distinetly less far forward than the frontal teeth; the large spine at the inner canthus projects the same distance forwards as the frontal teeth. The condition of the spine at the outer angle of the orbit appears to be characteristic of the earlier growth stages (Laurie, loc. cit.).

\section{Family RANINID正.}

Genus No'Topus, de Haan, 1841.

9. Notopus donsipes (Fabricius, 1793). See Alcock, 1896, p. 290. Locality. Station V. G, 2 \% $[33,34]$.

Remarks. $q 34$, C.l. $19 \mathrm{~mm}$., C.b. across base of antero-external spines $13 \mathrm{~mm}$. , fronto-orbital border $8.5 \mathrm{~mm}$.; $\&$ 33, C.l. $13 \mathrm{~mm}$., C.b. $9 \mathrm{~mm}$, fronto-orbital border $6 \mathrm{~mm}$. 
Alcock's description reads obscurely as regards the spines of the anterior border of the carapace; there are five spines on the fronto-orbital border, as he describes, but the spine forming the antero-external angle of the carapace on either side is not the outermost of the above series but an additional one, making a series of seven spines in all along the anterior border of the carapace. This is seen quite clearly in de Haan's figure (1841, pl. xxxv. fig. 5). It is presumably also not the ischinm but the merus of the chelipeds which Alcock intends to describe as trigonal, somewhat swollen, and having its outer surface tattooed with linear dents with hairy edges.

This is the first record of any member of the family Raninidø from the Red Sea.

\section{Subtribe BRACHYGNATHA.}

Superfamily OXYRH Y N HA.

Family MAMAIID五.

$=$ Maïdee, see Stebbing, 1905 (1) p. 22, and 1910, p. 290. I use the word, however, in its wider sense, not as = Alcock's Maiinæ.

Genus Camposcia, Latreille, 1829.

10. Camposcia Retusa, Latreille, 1829. See Alcock, 1895, p. 184.

Camposcia retusa, Nobili, 1906, p. 172.

Camposcia retusa, Klunzinger, 1906, p. 15, pl. 1. fig. 1.

Camposcia retusa, Laurie, 1906, p. 371.

Camposcia retusa, Stimpson, 1907, p. 19.

Locality. Station V. E, 1 q ovig. [35].

Remarks. C.1. $34 \mathrm{~mm}$. It is encrusted, as is usual in this species, with a very considerable quantity of sponges, etc.

\section{Genus Acanthonyx, Latreille, 1829.}

11. Acanthonyx elongatus, Miers, 1877. See Miers, 1877, p. 673, pl. 69. fig. 1.

Acanthonyx elongatus, Nobili, 1906, p. 172.

Acanthonyx elongatus, Klunzinger, 1906, p. 22.

Acanthonyx consobrinus, Paulson, 1875, p. 7, pl. 3. fig. 1 (nec A. consobrinus, A. M.Edw., 1863); fide Klunzinger, loc. cit.

Locality. Station IX. B, 1 o probably immature [36].

Remarks. C.l. including rostrum $22.5 \mathrm{~mm}$.

It differs from Miers's description and figare in (a) the tubercles of the carapace, there being three on the gastric region, one on the cardiac region, a small one on either side of the cardiac region and a trace of one on the intestinal (post-cardiac) region; (b) the small middle tooth of the lateral border of the carapace is more distinct than in Miers's figure and so also are 
the curves in front of and behind this. The specimen falls, however, under Klunzinger's description.

Klnnzinger gives some notes on the synonymy of the species. He considers that the specimens which Paulson put under $A$. consobrinus in 1875 really belong to the present species, but that $A$. consobrinus of A. Milne-Edwards, 1863 , is distinct. From this it would follow that the latter species has not been recorded from the Red Sea and should therefore be deleted from Nobili's list.

A. elongatus has not been recorded outside the Red Sea.

Genus Herbstia, H. Milne-Edwards, 1834.

12. Herbstia conniculata, Klunzinger, 1906. (Plate 44. fig. 2.) See Klunzinger, 1906, p. 27, pl. 1. figs. $4 a-b$.

Locality. Station V. A, 1 of probably adult [37].

Remarks. C.1. including rostrum $7.5 \mathrm{~mm}$., C.b. $8 \mathrm{~mm}$. The fingers gape proximally as shown in the figure. Lower border of propus $3.5 \mathrm{~mm}$.

Klunzinger's specimens are $q$. The present specimen is the only other recorded example of the species and the first $\delta$ recorded. The species has. thus not been found outside the Red Sea.

Gents Strubognathus, von Martens, 1866.

13. Stilbognathus erythraus, von Martens, 1866. See Klunzinger, 1906, p. 25.

Stylbognathus erythraeus, Nobili, 1906, p. 176.

Locality. Station V. E, 1 o [38], 1 \& ovig. [39].

Remarks. $\delta$, C.l. excluding the rostral horns but including the posterior triangle $22 \mathrm{~mm}$., rostral horn $7 \mathrm{~mm}$. Cheliped of the enlarged "breeding" type, the tingers gaping a good deal proximally: H.l. $6 \mathrm{~mm}$., lower border of propus $11 \mathrm{~mm}$., propus height $5.5 \mathrm{~mm}$.; $q 39$, C.l. $21 \mathrm{~mm}$., rostral horn $5 \mathrm{~mm}$.

Kossmann (1877, p. 15, pl. 1. fig. 1) gives a useful photograph of a dorsal view of the animal.

The species bas not been recorded outside the Red Sea.

Genus Ophthalmias, Rathbun, 1897.

=Stenocionops, Latr., 1825, et auct., not Leach, 1823, which latter replaces Pericera, Latr., 1825; see Rathbun, 1897, p. 157.

14. Ophthalmias curvirostris (A. M.-Edw., 1865). (Plate 45. fig. 4.) See Klunzinger, 1906, p. 24.

Stenocionops curvirostris, Nobili, 1906, p. 177.

Stenocionops curvirostris, Nobili, 1907, p. 108.

Stenocionops curvirostria, Klunzinger, 1906, loc. cit.

? Stenocionops cervicormis, von Martens, 1866, p. 379 ; nec Herbst, 1803. 
Locality. Station VII. E, 2 ㅇ (No. 41 ovig.) $[40,41]$.

Remarks. $q 41$ ovig.: C.1. excluding rostral horns $23 \mathrm{~mm}$., rostral horn I. 7 mm., eye-stalk 1 . measured from inner orbital angle $6.5 \mathrm{~mm}$., and supraocular spine l. measured also from inner orbital angle $7 \mathrm{~mm}$., R.1. $\div$ C.1. $=\cdot 30$; q 40 has C.l. 9 mm., R.l. $3 \cdot 5 \mathrm{~mm}$, and R.l. $\div$ C.l. $=\cdot 39$.

The following distinctions hold between the present specimens of 0 . curvirostris and specimens of O. cervicornis, Herbst, from Ceylon, examined by me (Laurie, 1906, p. 383) :-

1. The rostral horns are distinctly upturned at the tips in curvirostris, not in cervicornis. See Rathbun, however, as below.

2. The rostral horns are closely apposed in curvirostris, but in cervicornis, though the rostral horns are somewhat bowed outwards, their tips are well apart (e.g. $8 \mathrm{~mm}$. in a specimen with C.1. 45 mm.).

3. The triangular projection of the posterior border of the carapace is more broadly triangular and less elongate in curvirostris.

4. The form of the external maxillipedes presents two points of difference, both in regard to the ischium :-

(a) the ischium of curvirostris has a deep longitudinal groove on the exposed surface, there is in cervicornis only the merest trace of such a groove.

(b) in cervicornis the proximal portion of the inner margin of the ischium, just before the angle is reached, is strongly notched, so that a rounded window is formed when the two ischia are opposed, this window is open posteriorly as the proximal angles do not meet in the middle line, though each such angle bears a claviform seta and these meet across the middle line giving an appearance of completeness to posterior border of the window (Pl. 45. fig. 5); in curvirostris the proximal angle of the inner border of the ischjum is cut away and only very obscurely marked, so that the regions in question slope obliquely backwards away from each other and the window does not appear, the club-shaped setæe are present but are far from meeting in the middle line (Pl. 45. fig. 4).

5. The eye-stalks and the supra-ocular spines are subequal in curvirostris, whereas in cervicornis the eye-stalks are quite distinctly the shorter of the two.

Of the above points of difference the first is of doubtful value, Rathbun (Rathbun, 1911, p. 254) saying that the rostral horns have their tips recurved upward (but not that they are apposed) in a $\delta$ cervicornis from Amirante and a young $o$ from Seychelles which she describes. The condition of the ischia of the external maxillipedes may prove, however, to be a distinction of considerable importance. 
I do not share Nobili's doubt as to the distinctness of the two species from one another.

The only record of $O$. cervicomis from the Red Sea is that of von Martens, and, on the other hand, $O$. curvirostris has not been recorded outside the Red Sea and Persian Gulf. As pointed out by Nobili, von Martens made his identification when probably unaware of Milne-Edwards's description of $U$. curvirostris, published only the previous year. It would be of interest to re-examine von Martens's examples.

\section{Genus Cyphocarcinus, A. Milne-Edwards, 1868.}

15. Cyphucaroints minutus, A. M.-Edw., 1868. (Plate 44. fig. 3.) See Alcock, 1895, p. 254.

Cyphocarcinus minutus, A. Milne-Edwards, 1868, p. 73, pl. 19. figs. 7-12.

Cyphocarcinus minutus, Nobili, 1906, p. 177.

Cyphocarcinus minutus, Nohili, 1907, p. 109.

Irion capreolus, Klunzinger, 1906, p. 44.

Cyphocarcinus minutus, Rathbun, 1911, p. 255.

Locality. Station VIII. B, 1 q , [42].

Remarks. C.l. to base of rostral horns $7 \cdot 5 \mathrm{~mm}$., and to tip of rostral horns $9.25 \mathrm{~mm}$., rostral horn $1.2 \mathrm{~mm}$.

The figures which best represent the present specimen are those of Paulson (1875, pl. 2. fig. 1) of a young $\sigma$, size not stated, given under the name of Ixion capreolus. In Paulson's figure, however, the gastric hump is less marked and the rostral horns are longer than in my $q$ specimen. Klunzinger translates Paulson's description.

Nobili (1907, loc. cit.) gives a useful account of the species.

The present specimen differs strikingly, in three respects more particularly, from A. Milne-Edwards's account of $C$. minutus : (a) it will be seen from my figure that in the present specimen the pre-gastric region slopes a little forward so that it is not hidden in a dorsal view of the animal, as described by Milne-Edwards, and affords a considerable contrast from his fig. 10, which is referred to by Nobili as well representing his own specimens; (b) the rostral horns are not pressed against each other in their basal portion as described by Milne-Edwards, but stand well apart, contrasting strongly with bis figure 8 ; (c) the basal joint of the first antenna and the joint following, though of the same general type, are less shortened in the present example than in Milne-Edwards's figure, so that a distinctly different appearance results from a ventral view.

In regard to $(a)$ above my specimen appears to be similar to Rathbun's 'Sealark' specimens from Amirante and Coetivy (loc. cit.), and in regard to (b) Rathbun's specimens appear in some degree intermediate between mine and that of Milne-Edwards.

LINN. JOURN.-ZOOLOGY, VOL. XXXI. 
The type-specimen of Xenocarcinus tuberculatus of White, in the British Museum, has the appearance of having had a similar arrangement, the 4th pair of walking-legs is present and, though the 3rd pair is lost, the basipodites which remain suggest that the legs pointed more backward than in Miers's figure (Miers, 1874, pl. 2. fig. 1).

In the British Museum I find two unnamed males labelled " 85.14. Aden, at low water. Presented by Major G. W. Yerbury." In these the rostral horns are longer than in the present example, being more as in Paulson's figure. Rathbun (loc. cit.) also finds the rostral horns longer in her $\delta$ than in her o specimen. The two British Museum specimens are of the same size, C.l. $11 \mathrm{~mm}$.; the chelipeds are enlarged in both, being apparently of the type appropriate to breeding males.

\section{Family PARTHENOPID $\mathbb{E}$.}

Genus Parthenope, Fabricius, 1798.

For non-recognition of Weber, 1795 , and consequent non-acceptance of Daldorfia, Rath., 1904, see Stebbing, 1905 (2), p. 332.

16. Partheinope horrida (Linntus, 1758). See Alcock, 1895, 1. 279.

Parthenope horrida, Alcock, loc. cit.

Parthenope horrida, Nobili, 1906, p. 179.

Parthenope horrida, Klunzinger, 1906, p. 54.

Parthenope horrida, Stebbing, 1905 (1), p. 27.

Daldorfia horrida, Ratbbun, 1906, p. 886, pl. 14. fig. 5.

Daldorfia horrida, Rathbun, 1911, p. 259.

Locality. Station VIII. E, 1 o small [43].

Remarks. C.l. $14 \mathrm{~mm}$., C.b. $19 \cdot 25 \mathrm{~mm}$. , C.l. $\div$ C.b. $=\cdot 73$, larger (right). Ch.l. $25.5 \mathrm{~mm}$., smaller (left) Ch.l. $23.5 \mathrm{~mm}$., the right and left chelipeds. are thus respectively 1.82 and 1.68 the length of the carapace.

The teeth on the upper margins of the meri of the walking-legs aretriangular.

Fig. 1.

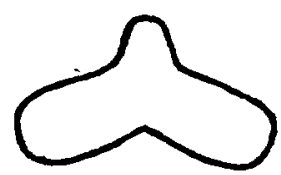

Parthenope horrida, ㅇ 43. Sternal hollow, $3 \mathrm{~mm}$. across.

The shape of the sternal hollow is shown in the accompanying textfigure. 
Genus Lambrus, Leach, 1815.

For non-acceptance of Parthenope, Weber, 1795, see Stebbing,

1905 (2), p. 332.

17. Lambrus (Aulacolambris) hoptonotus, Adams $\&$ White, 1848. See Alcock, 1895, p. 273.

Lambrus (Aulacolambrus) hoplonotus, Alcock, loc. eit.

Lambrus (Aulacolambrus) hoplonotus, Laurie, 1906, p. 389.

Parthenope (Aulacolambrus) hoplonotus, Rathbun, 1906, p. 885.

Localities. Station II., 1 j juv. [44]; Station VIII. A, 1 q non-ovig., but probably adult [45]; Station VIII. C, 1 o juv. [4 $\left.\dot{b}^{\circ}\right]$.

Remarks.

\begin{tabular}{|c|c|c|c|}
\hline C.l. & $\begin{array}{c}q 45 . \\
150\end{array}$ & $\begin{array}{c}\text { o } 46 . \\
7.5\end{array}$ & $\begin{array}{c}544 \\
7.5\end{array}$ \\
\hline$\ldots \ldots \ldots \ldots$, & $17 \cdot 0$ & . & $7 \cdot 75$ \\
\hline$\ldots \ldots \ldots \ldots \ldots$ & $26 \cdot 5$ & $\cdots$ & $10 \cdot 75$ \\
\hline Lat. Epi. spine (post. bord.) & $7 \cdot 25$ & , & $2 \cdot 5$ \\
\hline (n., & $38 \cdot 0$ & $19 \cdot 5$ & $19 \cdot 5$ \\
\hline${\text { C.b. }{ }_{1}} \div \mathrm{c} .1, \ldots \ldots \ldots \ldots \ldots \ldots \ldots$ & $1 \cdot 13$ & -. & 1.03 \\
\hline$\ldots \ldots \ldots \ldots \ldots$ & $1 \cdot 77$ & . & $1 \cdot 43$ \\
\hline Ch.1. $\div$ C.1. $\ldots \ldots \ldots \ldots \ldots$ & $2 \cdot 53$ & $2 \cdot 60$ & $2 \cdot 60$ \\
\hline at. Epi. spin & $\cdot 48$ & . & $\cdot 33$ \\
\hline
\end{tabular}

C.b.1 is measured across anterior bases and C..b.2 across tips of lateral epibranchial spines.

$\delta 44$ is well separated from the other two specimens. (a) All three specimens have the carapace set i with roundea tubercles, but while in $ᄋ 45$ and $\delta 46$ these are strongly developed and well granulated they are in $\delta 44$ less pronounced, and their granulation is inconspicuous; it follows that the latter specimen is much less "rough in general appearance than either of the other two.

(b) The orbits have a very different appearance; in +45 and $\delta 46$ the orbital margin bears a series of longitudinally elongated granulated tubercles which have somewhat the appearance of claws curving over the orbit, reminding one of the metal claws by which a jeweller sets a stone in a ring; in $\delta 44$ there are simply a few granules which do not obscure the large triangular emargination of the dorsal margin of the orbit. Running back from the apex of this emargination the fissure is well seen in $\delta 44$.

(c) The spines of the eheljped are smooth in $\delta 44$; in $q 45$ and $\delta 46$ they are, in dorsal view, considerably granulated. The detail of the granulation is as follows: each spine of the inner border of the hand is quite covered with granules dorsally, the spines of the outer margin of the hand form a series in which there is a gradual transition from the distal one, which is granular to its base, to the proximal one, which is granular only at its tip ; 
on the wrist only the tips of the spines are granular, more particularly in the longer ones; and on the arm there is a transition as in the hand, but in the reverse direction, i.e., a trace at the tip of the two distal ones, in the next one there are in addition one to three granules about the middle of its length, in the next the outer half or more is granular, and in the most proximal member of the series the granules extend almost to the base.

(d) In $\delta 44$ the lateral epibranchial spine appears to curve a little forwards, owing to the convexity of its posterior border, while in $q 45$ and $\delta 46$ it points in a straight line obliquely backward.

(e) In $\delta 44$ the lateral epibranchial spines are relatively shorter than in 95 . (In $\delta 46$ they are damaged.)

(f) In $\delta 44$ the lateral epibranchial spine is simple, while in $q 45$ and $\delta 46$ it bears on each side near its base a well-marked secondary spine (not to be confused with the quite separate spine to its inner side).

(g) The number of large spines on the outer margin of the hand differs, in $\delta 44$ there are six while in $q 45$ and $\delta 46$ there are eight.

Miers (1879, pp. 22-4) describes several varieties of this species. Specimens 45 and 46 appear to come close to White's type-specimen from "Eastern Seas," described by Miers, while specimen 44 closely resembles Ceylon examples examined by me (loc. cit.) and comes close to var. planifroms (Ceylon) and var. granulosus (Phillipine Islands and Corregidor), both of Miers.

Although in my Ceylon examples the resemblance is to specimen 44 of the present collection, the tubercles of the carapace are sharper than in it, and the orbital border is more as in specimens 45 and 46 .

Perhaps the most important of the contrasted characters in the above forms are the number of spines on the outer border of the hand and the condition of the lateral epibranchial spines.

$L$. hoplonotus has not hitherto been recorded from the Red Sea.

18. Lambrus (Rhinolambrus) Pelagicus, Rüppell, 1830. See Alcock, 1895, p. 267.

Lambrus (Rhinolambrus) pelayicus, Alcock, loc. cit.

Lambrus (Rhinolambrus) pelagicus, Nobili, 1906, p. 184.

Lambrus (Rhinolambrus) pelagicus, Klunzinger, 1906, p. 47

Lambrus (Rhinolambrus) pelagicus, Laurie, 1906, p. 389.

Locality. Station II., 1 శ, small [47].

Remarks. C.l. 7.5 mm., C.b. 7.5 mm., Ch.1. 19.5 mm., Ch.l. $\div$ C.l. $=26$. The cheliped length of this young $\delta$ agrees with that of a young $q$ of similar size from Ceylon (Laurie, loc. cit.). 


\section{Superfamily BRA OH Y R Y N C HA. Family PORTUNJD丑.}

Genus Caphyra, Guérin, 1832.

19. Caphyra monticelli, Nolili, 1901. (Plate 45. figs. 1, 1 a.) See Nobili, 1901, p. 10.

Caphyra Monticellii, Nobili, loc. cit.

Caphyra Monticellii, Nobili, 1906, p. 188.

Locality. Station VIII. E, 1 (?ठ์) [48].

Remarks. Probably of, the abdomen is missing. C.I. $5 \mathrm{~mm} .$, C.b. $5 \cdot 75 \mathrm{~mm}$, C.b. $\div$ C.1. $=1 \cdot 15$. The left hand is much more massive than the right: in the left cheliped H.l. (upper bord.) $4 \mathrm{~mm}$., F.l. (upper bord.) $2.5 \mathrm{~mm}$., lower border propus $6 \mathrm{~mm}$. and $H$. height $2.75 \mathrm{~mm}$.; in the smaller cheliped the same measurements are $2 \cdot 6,2 \cdot 6,5$, and $2 \mathrm{~mm}$. respectively.

There are small blunt tubercles on the upper inner border of the ischium of the cheliped instead of spinules. There are only two spines on the lower inner border of the ischium of the stmaller (right) cheliped, there are two tubercles in this position on the larger (left) cheliped. The four spines on the lower anterior border of the merus of the left cheliped are equal in size and of the same type as on the merus of the right cheliped. The tubercle on the outer surface of the palm at the region of the carpo-propal articulation is blunt, not spiniform. The upper border of the palm is as described by Nobili, but neither the well-developed crest nor the traces of a second one are present on the outer surface of the palm.

Thus this specimen differs from Nobili's specimen essentially $(\alpha)$ in the size and relations of the chelipeds, the left being much the more massive and its fingers much shorter in proportion to the palm; and (b) in having the armature of the hands less sharp.

The abdomen of the present specimen is missing. If $m y$ identification is correct and if the specimen is, as $I$ take it to be, a male, then the above points of difference of the chelipeds from Nobili's description, which was of a female, may be in some part sex-differences; they may also be in part related to size. Nobili's type-specimen had C.l. $4 \mathrm{~mm}$. and C.b. $5 \mathrm{~mm}$.; it was taken 25 miles north of. Massowah in 1893.

The front is asymmetrical in the present specimen, the outer tooth of the right frontal lobe being very inconspicuous, while that of the left lobe is distinct, though small. 
Genus LuPA, Leach, 1813.

$=$ Neptunus, de Haan, 1833. See Stebbing, 1902, p. 11, and 1908, p. 11.

20. LuPa AlcockI (Nobili, 1905). (Plate 44. figs, 1-1 c.) See Nobili, 1906, p. 191.

Neptunus (Hellenus) Alcocki, Nobili, loc. cit.

Locality. Station I. B, $1 \delta^{\pi}\left[49^{\circ}\right]$.

Remurks. C.l. $8 \mathrm{~mm}$; C.b. from tip to tip of the large 9th antero-lateral spines $16.25 \mathrm{~mm}$., across the line of the angles between .8 th and 9 th anterolateral teeth $12 \mathrm{~mm}$.; Ch.l. $16 \mathrm{~mm}$.; propus l. (inner lower bord.) $8.75 \mathrm{~mm}$.

Of the three teeth on the outer surface of the wrist one is distal and spiniform and two are proximal and blunt.

A point not referred to by Nobili is that there is a break in the salient crest of the large lateral spine where it curves back on the carapace towards the cardiac region.

The chelipeds are of approximately equal length, but the right chela is the more massive.

The only other example of this species recorded is the male with C.l. 6.75 mm., which formed Nobili's type-specimen and was taken at Djibouti.

$$
\begin{aligned}
& \text { Genus Charybis, de Haan, } 1833 . \\
& =\text { Goniosoma, A. M.-Edw., 1860; see Rathbun, 1897, p. } 161 \text {. }
\end{aligned}
$$

21. Charybdis erythrodactyla (Lam., 1818). See Nobili, 1907, p. 118, fig. 3.

Charybdis (Goniosoma) erythrodactyla, Nobili, 1906, p. 194.

Thalamita pulchra, Randall, 1840, p. 117, p1. 4 ; see Rathbun, loc. cit.

Charybdis erythrodactyla, Rathbun, 1906, p. 872, pl. 4 (coloured).

Locality. Station VII. B, 1 q immature [50].

Remarks. C.l. $16.25 \mathrm{~mm}$., C.b. (across the region of the last antero-lateral spines) $25 \mathrm{~mm}$.

Though the chelipeds are missing, and important characters are thus undeterminable, the specimen appears evidently to belong to C. erythrodactyla, agreeing with the group of small specimens described by Nobili (1906, p. 195).

There is granulation on the basal antennal joint both proximal and distal to the blunt laminar tubercle.

Genus Thatamita, Latreille, 1829.

22. Thalamita Poissonit (Audouin et Savigny, 1826). See Alcock, 1899 (1), p. 81 .

Thalamita Poissonii, Alcock, loc. cit.

Thalamita Poissonii, Nobili, 1906, p. 205.

Thnlamita Poissoni, Nobili, 1907, p. 120.

Thalamita poissom, Laurie, 1906, p. 419. 
Localities. Station I. B, 4 б [51-54], 5 우 [55-59]; Station I. E, 1 б probably adult $[60]$ : Station I. G, $1 \delta[61], 1$ \& $[62]$.

Remarks. The length of the carapace varies in the males from 11 to $16 \mathrm{~mm}$. and from 11 to $17.5 \mathrm{~mm}$. in the females.

In both sexes it is sometimes the right and sometimes the left cheliped which is the larger, thus it is the right in four of the males and three of the females, and the left in the remainder of the specimens.

I do not share Alcock's doubt as to the distinctness of this species from T. chaptalii. Points of difference are as follows :-

1. As pointed out by Alcock, the teeth of the antero-lateral border are in $T$. poissonii acute, and the last tooth is more spiniform and more prominent than the others.

2. As pointed out by Nobili, the fourth tooth of the antero-lateral border is in $T$. poissonii much smaller than the others.

3. Alcock notes that the teeth of the anterior border of the arm are in $T$. poissonii acute; this is so in the present specimens, in which they are three or four in number. So also are the other teeth of the cheliped acute, and this is conveniently seen in the case of the tooth on the upper surface of the propus, in front of the carpo-propal articulation. Borradaile (1902 (1), p. 201) records, however, a male from Suvadiva which "has the spines on the fore edge of the meropodite of the cheliped blunt," as in " $\%$. claptalii.

4. In place of the somewhat granular eminence on each antero-lateral portion of the gastric region in $T$. chaptalii there is in $T$. poissonii a short transverse granular ridge.

5. The present specimens contrast with those from the Gulf of Manaar placed by me (Laurie, loc. cit.) under $T$. chaptalii in the shape of the front; its outer limit is well marked and rounded in the present specimens instead of gently sloping, so that the anterior frontal margin is fairly straight transversely.

6. The hinder edge of the propodite of the last leg bears in $T$. poissonii several spinules, of which there is no trace in T. chaptalii. This difference is emphasized by Borradaile.

7. The setæ of the dorsal surface of the carapace are longer in the present specimens of $T$. poissonii than in the Gulf of Manaar examples of T. chaptalii mentioned above ; the difference, though not great, is constant.

8. An additional point is the red coloration (spirit-specimens) of the npper mero-carpal point of articulation ; this concerns both the articular process of the carpus and the margin of the articular cavity of the merus, and appears as a conspicuous red dot in a dorsal view of the animal as it lies in a position of rest. Colour in spirit is no doubt elusive, but in the present instance the red spot is clearly seen in all the specimens, but not to be made out at all in a series of 22 specimens of $T$. chaptalii from Gulf of Manaar which I have 
before me, though these latter show traces of colour on the fingers just as clearly as do the present specimens.

23. Thalamita admete (Herbst, 1803), var. savignyi, A. M.-Edw., 1861. See Alc. 1899 (1), p. 84 ; Nob. 1906, p. 206 ; Borr. 1902 (1), p. 202.

Thalamita almeta, var. savignyi, Alcock, loc. cit.

Thalamita admeta, var. Savignyi, Nobili, loc. cit.

? Thalamita admete, Rathbun, 1906, p. 874.

Locality. Station V.E, 1 \% [63]; Station X., 1 \% [64].

Remarks. Specimen 64 is immature, C.l. $11.5 \mathrm{~mm}$. , C.b. $19 \mathrm{~mm}$; it has lost its left cheliped. Specimen 63 is non-ovigerous, but appears to be mature, C.l. $14 \mathrm{~mm}$., C.b. $22 \cdot 75 \mathrm{~mm}$; its front is damaged.

The present examples have very strong resemblance also to var. admete, Herbst, 1803, but they fall within the limits of variation of specimens referred by Nobili to var. savignyi. One may note $(a)$ the transverse ridges of the carapace are in sharp relief ; $(b)$ the division between the two frontal lobes is not broad and deep (in specimen 63 this region is injured); (c) certain particulars in regard to the hands in specimen 63 (the left cheliped is lost in specimen 64), namely : the inner surface of each hand bears a median longitudinal granular ridge and the narrower (left) hand has, in addition, a second row of small granules below this, and the lower portion of its inner surface is also granular; the lower margin of the larger hand is smooth save for a few obsolescent markings, that of the smaller is granular, the granulation being continuous with the granular portion of the lower part of the inner surface; except for a few obsolescent granules the space between the two lower crests of the outer surface of the hand is smooth, a point of difference from Borradaile's Key (Borradaile, 1902 (1), p. 202); (d) each finger has a well-marked groove along its inner surface and the dactylus has the suggestion of a second groove above the other proximally; (e) in the larger specimen the 4th antero-lateral tooth of each side, though far from obsolescent, is smaller than the others, being about one-bitl the size of the third; in the smaller specimen it is rudimentary. From cases cited by Nobili it appears that the size of this tooth may be subject to considerable growth-change, assuming an increased relative size with the growth of the animal.

Rathbun (loe. cit.) describes three forms from the Hawaiian Islands, edwardsi, Borradaile, admete, Herbst, and auauensis, Rathbun, sp. nov., which come within the admete group, and to each she gives specific rank. She does not agree with the application of Herbst's name admete made by Alcock and by Borradaile, but believes it essential that forms included under it shall have a well-developed fourth side-tooth. One would like to know the sizes of the specimens which she discusses, and whether differences of the condition 
of the fourth side-tooth hold as between large specimens or to what extent such difterences may be due to growth-change. Rathbun remarks regarding the examples she puts under T:admete that "the description of $T$. savignyi, A. Milne-Edwards, applies very well to these specimens, except that the inner surface of the hand is not granular."

23 $a$. Thalamita admete (Herbst, 1803), var. intermenia, Bor\%, 1902.. See Borr. 1902 (1), p. 203 ; Nob. 1906, p. 208.

Thalamita admeta, var. intermedia, Borradaile, loc. cit.

Thalamita admeta, var. intermedia, Nobili, loc. cit.

Locality. Station X., 2 व $[65,66]$.

Remarks. Specimen 65 his C.l. $11.5 \mathrm{~mm}$. Specimen 66 has C.1. $12 \cdot 5 \mathrm{~mm}$.

In specimen 66 the crest on the basal joint of the right antemna has four spinules, and that of the left antenna five spinules; specimen 65 is typical with three spinules on each side.

24. 'Thalamita integra, Dana, 1852. See Alcock, 1899 (1), p. 85.

Thalamita integra, Nobili, 1906, p. 209.

Thalamita integra, Stimpson, 1907, p. 83.

Locality. Station VII. E, 1 q ovig. [67].

Remarks. C.1. $7 \mathrm{~mm}$., C.b. $11 \mathrm{~mm}$.

The ridge which Alcock refers to as running along the distal two-thirds of the outer surface of the larger hand is present in this specimen and is continued along the fixed finger ; on the narrower chela a similar ridge is present, and in addition one above it which runs to the gape of the tro. fingers.

It is the right chela which in the present specimen is the larger.

Subgenus Thalamitö̈Des, A. Milne-Edivards, 1869.

Thalamitöides has come to be treated as a genus, perhaps by accident rather than by design. I use the name in its original meaning. See A. Milne-Edwards, $\mathbf{1 8 6 9 ,}$ p. 146.

25. Thalamita (Thalamitoï̀ess) Tridens, 1 . M.-Edw., 1869, var. spiniGera (Nob., 1905). See Nobili, 1906, p. 213.

For the species, see A. Milne-Edwards, 1869, p. 149, pl. t. figs. 1-7.

Locality. No locality given, 1 q juv. [68].

Remarks C.l. $4 \mathrm{~mm}$.

The specimen shows the characters of var. spinigera, the basal joint of the second antenna bearing spines between the outer frontal lobe and the orbit, 
and the hands bearing seven spines on the upper border. Of the antennal spines above named there are three on the right antenna, of which the middle one is very small, and four on the left antenna, of which the two at the orbital end are small, particularly the inner of the two.

The line uniting the posterior teeth of the lateral border of the carapace is well marked, and the posterior gastric line is somewhat curved, with the convexity backwards, so that the general appearance of the lines on the carapace is as in A. Milne-Edwards's figure of $T$. quadridens (A. MilneEdwards, 1869, pl. 6. fig. 8).

The part of the carapace anterior to the posterior gastric line is seen by the aid of a lens to be closely covered with small low granules.

This appears to be essentially a Red Sea variety, and may perhaps come to be given specific rank.

Genus Podophthalmus, Lamarck, 1801.

(Original orthography Podophtalmus, not Podophthalmus.)

26. Podophthalmus vigil (Fabricius, 1798). See H. Milne-Edivards, 1834, p. 467.

Podophthalmus vigil, Nobili, 1906, p. 213.

Locality. Station IV., 1 o juv. [69].

Remarks. (1.l. $7 \mathrm{~mm}$., C.b. including spines $14 \cdot 5$, frontal b. $2 \cdot 5$, lateral epibranchial spine 5, length of post. bord. C. 5, eye-stalk including eye $6.75 \mathrm{~mm}$. The specimen is thus very small, H. Milne-Edwards's specimens were 2 to 4 inches in length.

Both chelipeds are lost, but it appenrs clear that the specimen comes under the present species, agreeing in other points with $H$. Milne-Edwards's description (loc. cit.) and figure (H. Milne-Edwards, Cuv., pl. 9. fig. 1), except that the two pairs of antennæ are of equal length, instead of the second being much shorter than the first pair.

\section{Family XANTHID丑.}

Genus Carpilius, Desmarest, 1825.

27. Carpiluus convexus (Forskål, 1775). See Alcock, 1898, p. 80.

Carpilius convexus, Nobili, 1906, p. 214.

Carpilius convexrus, Stimpson, 1907, p. 37.

Locality. Station VII. A, 1 \& [70].

Remarks. C.l. $50 \mathrm{~mm}$.

The pitting of the carapace extends over the whole of the dorsal surface; it is coarse inside the frontal and antero-lateral borders, less so in the middle region, and faint on the posterior slope. 
Genus Carpilodes, Dana, 1851.

28. Carpilodes levis, A. Milne-Elwards, 1873. See Nobili, 1906, p. 215. Locality. No locality given, 1 \& [71].

Remarks. ( (.1. 5.25 mm.

Areolæ $1 \mathbf{M}$ are not separated from the inner parts of the protogastric areolæ (2 II) ; Nobili calls attention to the variability which occurs in this respect in the species.

29. Carpilodes nugatus (H. Milne-Edwards, 1834). See Alcock, 1898, p. 84 .

Carpilodes rugatus, Nobili, 1906, p. 219.

Localities. Station VII. B, 1 s small [72] ; Station IX. B, 1 q ovig. [73]. Remarks. $q 73$, C.1. 6 mm., C.b. $11 \mathrm{~mm}$; o 72, C.1. $4 \cdot 4 \mathrm{~mm}$. , C.b. $8 \mathrm{~mm}$.

The specimens agree very closely with the figures of A. Milne-Edwards (A. Milne-Edwards, 1865, pl. 12. figs. 3-3b).

Genus Atergatrs, de Haan, 1833.

30. Atergatis roseus (Rüppell, 1830). See Alcock, 1898, p. 97. Atergatis roseus, Nobili, 1906, p. 2:29.

Localities. Station V. E, 1! $\delta[74]$; no locality given, 1 \% [75].

Remarks. ơ 74 , C.l. $16 \mathrm{~mm}$.; क 75 , C.1. $13 \mathrm{~mm}$.

In the following points the present examples approach A. integerrimus (Lamarck): (a) the cardiac region is partly indicated by a pair of short faint curved longitudinal creases placed with convexities facing each other ; (b) the dorsal surface of the carapace is irregularly and rather distantly pitted, especially near the frontal and antero-lateral borders ; (c) the upper edge of the hand is bluntly and not very conspicuously crested.

The essential reason for placing the specimens under the present species is the absence of any ridge or tooth from the lateral epibranchial angle.

$$
\begin{aligned}
& \text { Genus Platypodra, Bell, } 1835 . \\
& =\text { Lophacteea, A. M.-Edw., 1865 ; see Rathbun, 1897, p. } 159 .
\end{aligned}
$$

31. Platypodia anaglypta (Heller, 1861). See Alcock, 1898, p. 102.

Lophactaea anaglypta, Alcock, loc. cit.

Lophactea anaglypta, Nobili, 1906, p. 233.

Localities. Station V. B, 1 small [76]; Station V. E, 1 त [77], $3 q$ [78-80].

Remarks. $\$ 76$, C.l. $6 \mathrm{~mm}$. , C.b. $9.5 \mathrm{~mm}$; $\delta 77$, C.1. $9.5 \mathrm{~mm}$; $q 78$, C.J. $11 \mathrm{~mm}$. ; \& 79, C.1. $17 \mathrm{~mm}$.; $\& 80$, C.l. $19 \mathrm{~mm}$. and C.b. $28 \cdot 5 \mathrm{~mm}$. 
The carapace proportions apparently remain much the same during growth. Thus (..b. $\div$ C.l. is about 1.5 in both $q 76$ (C.l. $6 \mathrm{~mm}$ ) and q 80 (O.1. $19 \mathrm{~mm}$.).

The front does not present a fissure in any of the specimens.

Genns Zosimus, Leach, 1818.

(Original orthogrephy Zosimus, not Zozymuts.)

32. Zosnud aneos (Linneus, 1764). See Alcock, 1898, p. 104.

Zozymus neus, Nobili, 1906, p. 235.

Zozymus aneus, Stimpson, 1907, p. 42.

Locality. Station VII. C, 1 бั [81].

liemarks. C.l. $28 \mathrm{~mm}$.

Genus Xantho, Leach, 1815.

33. Xantho distiniunndus, de Haan, 1835. See Alcock, 1898, p. 113.

Xantho distinguendus, Nobili, 1906, p. 239.

Xantho distinguendus, Laurie, 1906, p. 401.

Localities. Station I. E, 1 ¿ [82], 2 q [83, 85 ovig.] ; a bottle labelled "Trials 1 " 1 \& ovig. [84].

Remarks. \& 82, C.1. $11.75 \mathrm{~mm}$; क 83 , C.1. $7 \mathrm{~mm}$.; \& 84, C.1. $7.5 \mathrm{~mm}$; i 85 , C.1. $10 \mathrm{~mm}$.

In specimens 82,84 , and 85 the right, and in specimen 83 the left, chela is the larger.

34. Xantho hydrophilus (Herbst, 1790). (Plate 43.fig. 1.) See Alcock, 1898, p. 118.

Xantho (Leptodisus) exaratus, Alcock, loc. cit.

Leptodius exaratus, Nobili, 1906, p. 240.

Leptodius exaratus, Nobili, 1907, p. 121.

Xantho (Leptodizes) exaratus, Laurie, 1906, p. 402.

Chlorodius exaratus, Stimpson, 1907, p. 52.

Leptodius exaratus, vur., Rathbun, 1911, p. 215.

Xantho hydrophilus, Stebbing, 1910, p. 297.

Localities. Station V. D, 2 क [86, 87 ovig.] ; Station VII. E, 1 \& [88].

Remarks. of 88, C.l. $7 \mathrm{~mm}$.; $q 87$ ovig., C.l. $5 \mathrm{~mm}$. ; ㅇ 86 , C.l. $5 \mathrm{~mm}$.

Under a lens the carapace, chelipeds, and walking-legs are seen in alk three specimens to be covered with granules which are obsolescent in some places but well developed in others: thus they are obsolescent on the posterior portions of the dorsal surface of the carapace, but well seen on the anterior and antero-lateral portions, the transverse edges of the areole standing out conspicuously; they form a beaded row along the margin of 
the front, and a less clear row of beads along the upper margin of the orbit; along the lobes of the antero-lateral borders of the carapace they tend to be dentiform in the two smaller specimens and absent in the larger one; on the rugulæ of the upper part of the outer surface of the band they are also clearly seen, but they are very obscure on the inner surface of the palm; on the upper margin of the meropodites, carpopodites, and propodites of the walking-legs they are crisp, two rows on the upper border of the dactylopodites being more or less spiniform; there are a few minute spinules on the lower margin of the propodites and dactylopodites ; on the lower margin of the dactylopodites, at the base of the terminal light brown horny claw and at right angles to it, is a strongly developed tooth, about a quarter to a third as large as the claw itself. The dactylopodites have thus for $X$. hydrophilus a well-armed aspect (Pl. 43. fig. 1). The antero-lateral teeth of the carapace are well developed and procurved.

Stimpson gives an interesting list of varieties of this highly variable species, but the present specimens do not fall under any variety described by lim. They have somewhat the granulation of his var. i, granulosus (loc. cit. p. 56, pl. 6. fig. 3), though the spiniform tendency of the granulation of the dactylopodites of the walking-legs is not mentioned by Stimpson, while the granules of the outer surface of its hand appear in his variety to be larger and more conspicuous than in my specimens. The antero-lateral teeth have much the appearance that they have in Stimpson's figure of his var. $h$, latus (loc. cit. pl. 6. fig. 9), i. e. less triangular than in granulosus, and the last two in particular are more tooth-like in form, but their margins do not bear large granules.

The denticulate armature of the walking-legs, and of the dactylopodites in particular, is noteworty; this and the general tendency to granulation all over the animal are differences from Alcock's description.

\section{Genus Erisus, H. Milne-Edwards, 1834.}

35. Erisus lemvimanus, Randall, 1840*. See Alcock, 1898, p. 131.

Etisus lavimanus, Nobili, 1906, p. 244.

Etisus lavimamus, Rathbun, 1906, p. 8501.

Etisus converus, Stimpson, 1907, p. 36, pl. 5. fig. 2.

Locality. No locality given, 1 of [89], 1 q ovig. [90].

Remarks. \& ovig. 90 , C.1. $17.5 \mathrm{~mm}$., C.b. $25 \cdot 25 \mathrm{~mm}$., Ch.l. $30 \mathrm{~mm}$.; o 89, C.l. $16 \mathrm{~mm}$., C.b. $23.75 \mathrm{~mm}$., Ch.l. $31 \mathrm{~mm}$, fronto-orbital b. $14.75 \mathrm{~mm}$, frontal b. $7 \mathrm{~mm}$.

It will be noticed that the chelipeds of the $\delta$ have by no means yet attained their enlarged condition, though the $q$, which is only a little larger, is ovigerous.

In the $q$ specimen the right, and in the $\delta$ the left, chela is the more massive.

* For date see p. 425. 
Genus ACT גA, de Haan, 1833.

36. Aстала томектоsА (H. Milne-Edwards, 1834). See Alcock, 1898, p. 140. Actea tomentosa, Nobili, 1906, p. 252. Acteodes tomentosus, Stimpson, 1907, p. 44.

Locality. Station VII. C, 1 \& non-ovig., but apparently adult [91].

Remarks. C.l. $16 \mathrm{~mm}$., C.b. $24 \cdot 75 \mathrm{~mm}$., C.l. $\div$ ().b. $=\cdot 65$.

37. Actara hirsutissima (Rüppell, 1830). See Alcock, 1898, p. 141. Actaa hirsutissima, Nobili, 1906, p. 252.

Localities. Station V. A, 8 small [92-99] ; Station V. B, 1 đ [100], 1 ㅇ small [101]; Station V. C, 1 q small [102]; Station V. E, $2 \approx$ [103-104]; no locality given, $1 \delta[105]$.

Remarks. The largest $\delta$ has C.I. $15 \mathrm{~mm}$, and C.b. $23.5 \mathrm{~mm}$., so that C.1. $\div$ C.b. $=\cdot 64 ;$ C.1. of smallest specimen $3 \mathrm{~mm}$.

38. Actad garketti, Rathbun, 1906. See Rathbun, 1906, p. 852, pl. 9. fig. 8 .

Actea garretti, Rathbun, 1911, p. 218.

Actea rufopunctata, var. retusa, Nobili, 1906, p. 253.

Locality. Station IX. A, 1 ठ [106], 1 \& [107].

Remarks. o' 106, C.1. $8 \mathrm{~mm}$., C.b. $11.5 \mathrm{~mm} .$, C.l. $\div$ C.b. $=\cdot 69$; $q$ 107, C.1. $7 \mathrm{~mm}$., C.b. $10 \cdot 75 \mathrm{~mm}$., C.. $\div$ C.b. $=\cdot 66$.

39. ACт дra polyacantha (Heller, 1861). See Heller, 1861, p. 339, pl. 3. fig. 21.

Chlorodius polyacunthus, Heller, loc. cit.

Actaa polyacantha, Nobili, 1906, p. 259.

Actrea polyacantha, Rathbun, 1911, p. 222.

Localities. Station V. A, 1 \% [108]; Station VII. D, 1 q non-ovig., but apparently adult [109].

Remarks. $q$ 109, C.l. 7 mm., C.b. $10 \mathrm{~mm} .$, C.l. $\div$ C.b. $=\cdot 7$; o 108 , C.l. $3 \cdot 75 \mathrm{~mm}$., C.b. $5 \cdot 25 \mathrm{~mm}$., (j.1. $\div$ C.b. $=\cdot 68$.

This species is evidently allied very closely indeed to the Australian species peronii of $\mathrm{H}$. Milne-Edwards (Alcock, 1898, p. 150) and its Indian variety squamosa of Henderson (Henderson, 1893, p. 357, and Laurie, 1906, p. 404). Alcock suggests with a query that the two species may be synonymous. I have not sufficient new material before me to warrant in my opinion their union as yet. Rathbun keeps them apart and calls attention to the intermediate position occupied by $A$. polyacantha between peronii, H. M.-Edw., and spinosissima, Borradaile. 
40. Actal grantiata (Audouin et Savigny, 1826). See Alcock, 1898, p. 151 .

Actaa granulate, Nobili, 1906, p. 261.

Actaa granulata, Nobili, 1907, p. 127.

Actaa pura, Stimpson, 1907, p. 44, pl, 5. fig. 7.

Actea granulnta, Stebbing, 1905 (1), p. 30.

Localities. Station I. B, 2 $\delta[110,111]$; Station I. E, $1 \delta$ small [112], $1 q$ small [113]; Station I. J, 1 क [114] 1 \% [115]; Station I. L, $1 \delta$ [116]; no locality given, $1 \delta[117\rceil, 4$ \% [118, 119, 120, 121 ovig.].

Remarks. $\delta$ juv. 113, C.l. $6.2 \mathrm{~mm}$; o 110, C.l. $21 \mathrm{~mm}$; q juv. 112 , C.l. $4 \mathrm{~mm}$.; q ovig. 121, C.l. $15.5 \mathrm{~mm}$.

41. Actea fossulata (Girard, 1859). See Alcock, 1898, p. 148.

Actea fossulata, Nobili, 1906, p. 262.

Actaa fossulata, Nobili, 1907, p. 126.

Localities. Station V. C, $1 \delta$ [122]; Station VII. B, $1 \delta$ [123]; Station VII. D, 1 क [124], 1 \& [125]; Station VII. E, $1 \delta$ [126].

Remarks.

\begin{tabular}{|c|c|c|c|c|}
\hline c.1. ...... 125 오. & $\begin{array}{c}123 \delta . \\
3 \cdot 1\end{array}$ & $\begin{array}{l}122 \text { む. } \\
3 \cdot 25\end{array}$ & $\begin{array}{c}124 d: \\
6 \cdot 0\end{array}$ & $\begin{array}{l}126 \mathrm{o} \\
7.75 \mathrm{~mm} .\end{array}$ \\
\hline C.b. ...... 5.25 & $4 \cdot 75$ & 5.0 & $9 \cdot 0$ & $12 \cdot 0 \mathrm{~mm}$. \\
\hline C.1. $\div$ C.b..... $\cdot 66$ & $\cdot 65$ & $\cdot 65$ & $\cdot 66$ & 65 \\
\hline
\end{tabular}

No growth-change in the ratio is indicated by the above measurements.

Genus Chlorodiella, Rathbun, 1897.

=Chlorodius, HI. M.-Edw., 1834, not Leach, 1823, which latter = Atelecychus, Leach, 1814 ; see Rathbun, 1897, p. 157.

42. Chlorodielda niger (Forskål, 1775). See Alcock, 1898, p. 160.

Chlorodius niger, Alcock, loc. cit.

Chlorodius niger, Nobili, 1906, p. 262.

Chlorodius niger, Nobili, 1907, p. 128.

Chlorodius niger, Stimpson, 1907, p. 50.

Chlorodiella [=Chlorodius] niger, Laurie, 1906, p. 405.

Chlorodiella niger, Rathbun, 1906, p. 857 (synonymy).

Localities. Station I. J, 2 \& $[154,166]$; Station V. A, 3 б $[132,133$, $142], 2$ q $[129,130]$; Station V. E, 6 o $[147,153,160-163], 2$ 우 [143, $146]$; Station VII. D, 7 \& $[134,138,144,148,156,157,164], 10$ ㅇ $[127$, $128,135,139,140,141,145,150,151,152]$; no locality given, $3 \delta[131$, $158,165], 5$ 우 $[136,137,149,155,159]$.

Remarks. The above include 40 specimens, and as their range of size is considerable, I take the opportunity which so large a series affords of making a study of growth-change in regard to certain variable characters. Three characters are selected and their conditions set forth in the following table, which includes also the size and sex and a statement as to which is the larger cheliped:- 


\begin{tabular}{|c|c|c|c|c|c|c|c|}
\hline $\begin{array}{c}\text { No. of } \\
\text { specimen. }\end{array}$ & Sex. & & .1. & $\begin{array}{c}\text { Number of } \\
\text { lobes of ant.--iat. } \\
\text { bord. C. which } \\
\text { end in procurved } \\
\text { spine-like } \\
\text { points. }\end{array}$ & $\begin{array}{c}\text { Condition of } \\
\text { tubercle or spine } \\
\text { on anterior margin } \\
\text { of arm. }\end{array}$ & $\begin{array}{c}\text { Armature } \\
\text { of posterior } \\
\text { margin of } \\
\text { arm. }\end{array}$ & $\begin{array}{l}\text { r Larger } \\
\text { chela. }\end{array}$ \\
\hline $\begin{array}{l}127 . \\
128 . \\
129 . \\
130 . \\
131 . \\
132 . \\
133 . \\
134 . \\
135 . \\
136 . \\
137 . \\
138 . \\
139 . \\
140 . \\
141 . \\
142 . \\
143 . \\
144 . \\
145 . \\
146 . \\
147 . \\
148 . \\
149 . \\
150 . \\
151 . \\
152 . \\
153 . \\
154 . \\
155 . \\
156 . \\
157 . \\
158 . \\
159 . \\
160 . \\
161 . \\
162 . \\
163 . \\
164 . \\
165 . \\
166 .\end{array}$ & 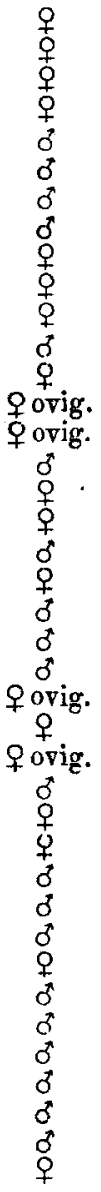 & $\begin{array}{r}3 \cdot 5 \\
3 \cdot 7 \\
3 \cdot 7 \\
4 \cdot 0 \\
4 \cdot 0 \\
4 \cdot 5 \\
4 \cdot 5 \\
5 \cdot 0 \\
5 \cdot 0 \\
5 \cdot 0 \\
6 \cdot 0 \\
6 \cdot 0 \\
6 \cdot 0 \\
6 \cdot 0 \\
6 \cdot 0 \\
6 \cdot 5 \\
6 \cdot 5 \\
6 \cdot 5 \\
6 \cdot 7 \\
7 \cdot 0 \\
7 \cdot 2 \\
7 \cdot 5 \\
7 \cdot 5 \\
7 \cdot 7 \\
8 \cdot 0 \\
8 \cdot 0 \\
8 \cdot 0 \\
8 \cdot 0 \\
8 \cdot 0 \\
9 \cdot 0 \\
9 \cdot 0 \\
9 \cdot 0 \\
9 \cdot 0 \\
9 \cdot 5 \\
9 \cdot 5 \\
10 \cdot 0 \\
11 \cdot 0 \\
11 \cdot 0 \\
11 \cdot 5 \\
12 \cdot 0\end{array}$ & $\begin{array}{l}\mathrm{mm} . \\
\mathrm{mm} . \\
\mathrm{mm} . \\
\mathrm{mm} . \\
\mathrm{mm} . \\
\mathrm{mm} . \\
\mathrm{mm} . \\
\mathrm{mm} . \\
\mathrm{mm} . \\
\mathrm{mm} . \\
\mathrm{mm} . \\
\mathrm{mm} . \\
\mathrm{mm} . \\
\mathrm{mm} . \\
\mathrm{mm} . \\
\mathrm{mm} . \\
\mathrm{mm} . \\
\mathrm{mm} . \\
\mathrm{mm} . \\
\mathrm{mm} . \\
\mathrm{mm} . \\
\mathrm{mm} . \\
\mathrm{mm} . \\
\mathrm{mm} . \\
\mathrm{mm} . \\
\mathrm{mm} . \\
\mathrm{mm} . \\
\mathrm{mm} . \\
\mathrm{mm} . \\
\mathrm{mm} . \\
\mathrm{mm} . \\
\mathrm{mm} . \\
\mathrm{mm} . \\
\mathrm{mm} . \\
\mathrm{mm} . \\
\mathrm{mm} . \\
\mathrm{mm} . \\
\mathrm{mm} .\end{array}$ & $\begin{array}{l}3 \\
3 \\
3 \\
3 \\
3 \\
3 \\
3 \\
3 \\
3 \\
3 \\
3 \\
3 \\
3 \\
3 \\
2 \\
3 \\
3 \\
2 \\
3 \\
3 \\
2 \\
3 \\
2 \\
2 \\
3 \\
2 \\
2 \\
2 \\
2 \\
2 \\
2 \\
3 \\
1 \\
2 \\
0 \\
1 \\
0 \\
1 \\
0 \\
0\end{array}$ & 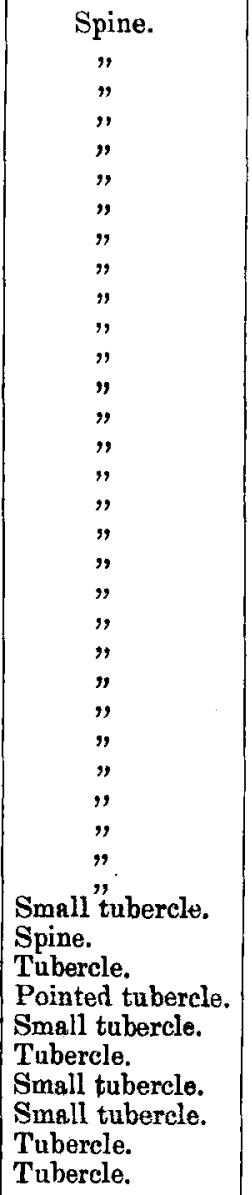 & $\begin{array}{c}\text { Spiniform. } \\
" \\
" \\
" \\
" \\
" \\
" \\
" \\
" \\
\text { Granular. } \\
\text { Spiniform. } \\
\text { Granular. } \\
" \\
" \\
" \\
" \\
" \\
" \\
" \\
" \\
" \\
" \\
" \\
" \\
" \\
" \\
" \\
"\end{array}$ & $\begin{array}{l}\text { Left. } \\
\text { Right. } \\
\text { Letit. } \\
\text { Right. } \\
\text { Right. } \\
\text { Right. } \\
\text { Left. } \\
\text { Right. } \\
\text { Left. } \\
\text { Left. } \\
\text { Right. } \\
\text { Right. } \\
\text { Left. } \\
\text { Right. } \\
\text { Right. } \\
\text { Leit. } \\
\text { Right. } \\
\text { Leet. } \\
\text { Right. } \\
\text { Left. } \\
\text { Left. } \\
\text { Left. } \\
\text { Left. } \\
\text { Right. } \\
\text { Left. } \\
\text { Left. } \\
\text { Right. } \\
\text { Left. } \\
\text { Left. } \\
\text { Right. } \\
\text { Left. } \\
\text { Right. } \\
\text { Left. } \\
\text { Right. } \\
\text { Right. } \\
\text { Right. } \\
\text { Right. } \\
\text { Left. } \\
\text { Left. } \\
\text { Left. }\end{array}$ \\
\hline
\end{tabular}

It will be noticed that, as a rule, crabs with C.l. from 3.5 to $6.5 \mathrm{~mm}$. have the last three of the antero-lateral lobes spiniform, those with C.l. 7 to $9 \mathrm{~mm}$. have the last two lobes spiniform, those with C.l. 9.5 to $11 \mathrm{~mm}$. tend to have only the last lobe spiniform, and that in those with C.l. above $11 \mathrm{~mm}$. there is an absence of the spiniform condition in all the lobes.

It will be further noted that the above is only an average relation and that variability is not the same in crabs of all sizes. Thus, where C.l. is 3.5 to 
$6 \mathrm{~mm}$., variability is practically nil, whereas variability is high in crabs with C.l. from 9 to $11 \mathrm{~mm}$.

The spiniform character of the tooth on the anterior edge of the arm gives place to the tubercular condition in crabs whose C.l. has reached about $9 \mathrm{~mm}$.

The spiniform armature of the posterior edge of the arm becomes granular when the C.l. reaches about $6 \mathrm{~mm}$.

Another point to be noted is that ovigerous females occur with C.I. of only $6 \mathrm{~mm}$. and that the different conditions of the characters above described are thus related with size rather than with sexual maturity; this is quite usual among crabs. On the other hand, the same ovigerous specimens have the broadened form of abdomen, an example of a character associated with sexual maturity rather than with size.

The number of individuals in which the right or left hand respectively is the larger is approximately equal, thus the right is larger in 19 and left in 21 individuals.

Some notes on the high variability of this species are given by $\mathrm{A}$. MilneEdwards (1873 (1), p. 214).

42 a. Chlorodielda niger, var. cy'lekrea (Dana, 1852). See Dana, 1852, p. 213 , pl. 12. figs. $2 a-c$.

Chlorodius cytherea, Dana, loc. cit.

Chlorodius cytherea, Stimpson, 1907, p. 50.

Localities. Station V. G, 1 \& juv. [167], 5 q juv. [168-172]; Station IX. A, 4 \& $[173-176], 2$ q ovig. $[177,178]$.

Remarks. C. 1. ranges in the of specimens from 2 to $4.5 \mathrm{~mm}$. and in the $\delta$ from 3 to $5.25 \mathrm{~mm}$. In the largest $\delta$ (176) C.b. is $8.25 \mathrm{~mm}$. and C.b. $\div$ C.1. $=1 \cdot 57$.

The length of the larger cheliped is related to the carapace length as follows :-

\begin{tabular}{|c|c|c|c|c|c|c|}
\hline C.1. & $\begin{array}{l}177 \text { } q \text { ovig. } \\
\ldots \quad 40\end{array}$ & $\begin{array}{c}178 \text { 우 ovig. } \\
45\end{array}$ & $\begin{array}{c}1730^{\circ} \\
4.0\end{array}$ & $\begin{array}{c}1745 \\
4 \cdot 75\end{array}$ & $\begin{array}{c}175 \delta . \\
5.0\end{array}$ & $\begin{array}{l}176 \mathrm{\sigma} . \\
5.25 \mathrm{~mm} .\end{array}$ \\
\hline Ch.1. & $\ldots 7.75$ & 8.75 & 8.0 & $9 \cdot 75$ & $12 \cdot 0$ & $11.25 \mathrm{~mm}$ \\
\hline Ch.1. $\div$ C.1. & .. 1.94 & 1.94 & $2 \cdot 00$ & $2 \cdot 05$ & $2 \cdot 40$ & $2 \cdot 10$ \\
\hline Larger Ch. & ... Right & Right & Left & Left & Right & Left \\
\hline
\end{tabular}

C. cytherea (Dana) is included by Alcock (Alcock, 1898, p. 160) as a synonym of $C$. niger. It appears possible that it may come to be re-elevated to specific rank, but I have not sufficient data to warrant my taking this step.

Var. cytherea has not hitherto been recorded from the Red Sea.

LINN. JOCRN.-ZOOLOGY, VOL. XXXI. 
Genus Phymodius, A. Milne-Edwards, 1863.

43. Phymodius ungulatus ( $H$. Milne-Edwards, 1834). See Alcock, 1898, p. 162.

Phymodius ungulatus, Nobili, 1906, p. 264.

Phymodius ungulatus, Nobili, 1907, p. 129.

Phymodius ungulatus, Rathbun, 1906, p. 857.

Phymodius ungulatus, Borradaile, 1902 (2), p. 259.

Phymodius monticulosus, Alcock, 1898, p. 163.

Phymodius monticulosus, Nobili, 1906, p. 264.

Phymudius obscurıs, Rathbun, 1906, p. 858.

Locality. Station VII. D, 10 d [179-188], 6 क (1. ovig.) [189-194].

Remarks. of C.l. varies from 4.25 to $6.5 \mathrm{~mm}$. ; o ovig. C.l. $5 \mathrm{~mm}$.

In five of the males the right, and in five the left, chela is the larger.

The specimens fall under Alcock's description of $P$. ungulatus.

Tegarding the inclusion of $P$. obscurus (Lucas) (=P. monticulosus (Dana)) under $P$. ungulatus, see Borradaile, loc. cit., but also Nobili, 1906, loc. cit.

44. Phymodios sculptus (A. Milne-Edwards, 1873). See Alcock, 1898, p. 164 .

Phymodius sculptus, Nobili, 1906, p. 265.

Localities. Station VII. B, 1 ๙ [195]; Station IX. A, $2 \approx[196,197]$, 5 ㅇ [198-202].

Remarks. The specimens show growth-change in regard to the condition of the antero-lateral lobes. In the two smallest specimens, $q 198$ (C.1. 3.9 mm.) and $q 199$ (C.l. $4.3 \mathrm{~mm}$.), all four lobes are produced into procurved spines; in $q 200$ (C.l. $4.7 \mathrm{~mm}$.) the three most posterior lobes are produced into procurved spines; and in all the remaining five specimens with C.l. ranging from 7 to $9 \cdot 25 \mathrm{~mm}$. the last two only of the lobes are so produced. C.l. of these last five specimens is as follows:- $q 7 \mathrm{~mm}$; $q 7.5 \mathrm{~mm}$; ठ $8.25 \mathrm{~mm}$.; के $9 \mathrm{~mm}$. ; क $195,9 \cdot 25 \mathrm{~mm}$.

In $\delta 195$ the right, and in the other two specimens the left, chela is the larger.

Genus Chlorodopsis, A. Milne-Edwards, 1873.

45. Chlorodopsis arabiod, n. sp. (Plate 42. figs. 1-1b; Pl.-43. figs. 2, $4 a-4 d$.)

Localities. Station V. E, 3 ठ [203-205]; Station VI. 1 đ [212] ; Station X. $1 \delta[206], 4$ \% [207-210]; no locality given, Crossland's label reads "A part of the fauna of two dead valves of $M$. margaritifera which were covered by sponges etc. and supported a regular microcosmos of life," 1 o adult non-ovig. [211].

Description of $\delta$ 203.-The entire carapace is cut into distinct areolæ, isolated by broad fairly deep channels. All the areolæ are granulated : those 
of the posterior half are closely covered with small rounded granules (smaller and more numerous than in C. areolata (H. M.-Edw.)). The areolæ of the anterior half of the carapace have a more lumpy surface, they are more prominent and end more abruptly in their anterior portions, but slope off gradually posteriorly, and the granules covering them have also their more prominent part directed anteriorly and the dorsal surface planed off, as it were, posteriorly, so as to slope gradually backwards; the granules also are more irregular in size on the anterior part of the carapace, larger ones tending to cluster at the anterior margins of the areolæ, as may be well seen, for example, in $2 \mathrm{~F}$, where an appearance is produced which contrasts markedly with the rounded character of the same areolæ in C.areolata. The dividing channels are naked; they are smooth in front of the cervical groove, but tend to be obscurely granular behind this. There is no hair on the dorsal surface of the carapace, except a bristle or two here and there.

The front is distinctly and broadly cut by a $U$-shaped notch into two lobes, the outer angle of each of which forms a separate lobule. The free margin of the large inner froutal lobes bears a neat row of bead-like granules.

The three fissures of the granular orbital margin are well marked, giving a lobed appearance.

The antero-lateral border is divided into four rounded-triangular lobes, in addition to the outer orbital angle, of which the third is the most prominent. The greatest breadth of the carapace is therefore across this region.

All the areolæ of Dana's scheme are clearly visible and some of them are further subdivided : $2 \mathrm{M}$ is divided by a longitudinal groove into a smaller inner and a larger outer portion, $6 \mathrm{~L}$ is subdivided into two, the tooth $\mathrm{S}$ is distinct from the areola $1 \mathrm{R}, 2 \mathrm{R}$ is divided into two; the narrow median anterior process of $3 \mathrm{M}$ runs forward between the posterior portions of the inner borders of $2 \mathrm{M}, 1 \mathrm{P}$ is shaped as in $C$. areolata, having a median notch anteriorly, corresponding with the median posterior projection.

The epistome is smooth, the sub-hepatic and sub-branchial regions are granulated, as also the sternum between the chelæ; granulation becomes obscure and pitting mingles with it on the sterna between the walking-legs. All these regions are naked or practically so.

There is an inconspicuous granulated sub-hepatic tubercle.

The outer distal angle of the basal antennal joint is drawn out into the large orbital hiatus, so as to lie against the inner angle of the lower orbital margin, but it falls very far short of filling the hiatus; the inner distal angle falls short of the hiatus and slopes obliquely where it comes in contact with the turned-down outer frontal lobe. The antennal flagellum arises from the basal joint where the latter makes an angle with the outer frontal lobe, and so lies in the hiatus.

The exposed surface of the external maxillipedes is naked, but the inner margin of the ischium has a short fringe of delicate hairs, very different from 
the stout fringe in C. areolata. The merus is granular; it has a prominent rounded, somewhat upturned antero-external angle; its anterior margin is notched, as also is its antero-internal angle, proximal to the latter notch is a smooth-floored depression. The ischium has a slight granulation anteriorly and slight pitting posteriorly; it has a longitudinal groove to the inner side of the middle line.

Chelipeds subequal in length, a little less than twice the length of the carapace, but one (left) chela is considerably the more massive. The whole surface of the chelipeds, including the larger rounded tubercles of the exposed surface of the wrist ( 2 tubercles mark the inner angle) and the tubercles of the upper border of the hand, is granulated. On the outer surface of the hand the tubercles become smaller, particularly on the lower part of the taberculated area, and smooth, and tend to run in 4 longitudinal rows, of which the 3rd, counting from above, runs along the middle and is much the best defined, and the 4th runs on to the proximal portion of the fixed finger. The fingers are well arched, the apposed borders not meeting except at their cup-shaped tips, and each armed with three teeth. The arrangement of these teeth is the same in the two chelæ, but their relative proportions differ a good deal. In both chelie those of the movable finger are equidistant, while the distal tooth of the fixed finger is well removed from the other two and faces the large gap distal to the third tooth of the dactylus. In the smaller chela these teeth are of approximately equal size and not particularly large, bat in the larger chela the 1st and 3rd of the dactylus and the 2nd of the fixed finger are enlarged. Each dactylus has a few granules on its upper margin proximally, also a pitted groove on its upper margin, and both dactylus and fixed finger have two pitted grooves on the outer surface.

Chelipeds in $q$ (specimen 211) are little more than one-half as long again as the carapace. They are less massive than in the $\delta$, subequal and very similar. The fingers are less strongly arched than in the $\delta$, but, as in the $\delta$, they only meet at their hollowed tips. The teeth of the fingers are not enlarged except the middle one of the fixed finger, and this by no means to. the same extent as in the $\delta$. The armature is sharper, the granules of the tubercles of the wrist and upper border of the hand are crisp, the two tubercles of the inner angle of the wrist are spiniform and curved, the smooth tubercles of the outer surface of the band are conical and pointed; on the same surface of the hand the tubercles extend almost to the ventral margin. Some of the above differences may be due to the smaller size of the $q$ specimen described as compared with the described of; it has, however, though non-ovigerous, the well-fringed broad abdomen, which may be taken to indicate sexual matarity.

The dorsal margin of the walking-legs, the ventral margin of their last two joints, and to a less extent the posterior surface of their last three joints bear 
fairly long scattered setx, which do not, however, hide the armature beneath them. 'The lower and posterior surfaces of the meropodite are granular, the anterior surface is smooth, the upper border bears a row of about seven long sharp teeth. The carpopodite has a double row of teeth on its dorsal border and a third row on the upper part of the posterior surface. The anterior and posterior rows of teeth are continued along the propodite, the posterior one being brought up to a higher level; the middle row is continued halfway along the propodite in the 1st, not so far in the $2 \mathrm{nd}$, a single tooth in the 3rd, and not at all in the 4 th walking-leg. The teeth are continued along the upper edge of the dactylopodite. There are a few small teeth distally on the lower border of the meropodite, a single distally directed sharp tooth on the distal end of the lower border of the propodite, and two rows of small teeth on the lower border of the dactylopodite, terminating in a pair of larger ones at the base of the brown claw.

The abdominal terga are in both sexes smooth for the most part, with a few setse along the lines of articulation of the segments. The margin of the abdomen is fringed inconspicuously with short setæ in the $\delta$, and in the $q$ with conspicuous long setæ. The abdomen is 7-segmented in the $q$ and 5 -segmented in the $\delta$.

Colours in spirit whitish, with the anterior portion of the carapace and the meri and carpi of the chelipeds a faint orange-red, the same colour much deeper on the hands and also on the exposed surface of the external maxillipedes; fingers chocolate-brown with white tips, the colour of the fixed finger extends a short but quite evident distance along the lower border and both surfaces of the hands.

Remarks. The smaller specimens differ from the larger ones as follows :-

(1) The armature is sharper: thus the granulation of the carapace and chelipeds is crisp, and the tubercles of the chelipeds are dentiform, the two at the inner angle of the wrist in particular are stout curved spines.

(2) The areolæ are less distinct.

(3) The antero-lateral lobes tend to be spiniform and procurved (see Table, p. 454).

(4) In the young $\delta$ the chelæ show less differentiation from each other and from the $q$ type, and in the young o the abdomen is fringed with short inconspicuous setwo only.

Apart from the above changes, associated with growth, there appears to be considerable variation in the distinctness of the granulation and areolation of the carapace, this being most pronounced in specimens 206 and 212.

The following table illustrates certain growth-changes, together with some characters of the genus Chlorodopsis, and also shows that either cheliped may the the larger in the present species:- 


\begin{tabular}{|c|c|c|c|c|c|c|c|c|c|c|}
\hline & $q 210$. & |q209. & $\$ 207$. & $q 208$. & q 211. & 8212. & 8205. & 8203 & $\delta 206$. & 8204. \\
\hline C.1. & $5 \cdot 0$ & $6 \cdot 1$ & $7 \cdot 0$ & 70 & 7.5 & $6 \cdot 75$ & $6 \cdot 75$ & $8: 50$ & $9 \cdot 0$ & $9 \cdot 25$ \\
\hline c.b & 6 & 8.5 & $9 \cdot 75$ & $10 \cdot 0$ & 1075 & $9 \cdot 75$ & 100 & $12 \cdot 75$ & $14 \cdot 0$ & $13 \cdot 7 \tilde{5}$ \\
\hline Front & 5 & 60 & $6 \cdot 75$ & 675 & $7 \cdot 25$ & 6.75 & 675 & $8 \cdot 5$ & $8 \cdot 75$ & $9 \cdot 0$ \\
\hline Frontal b. & $2 \cdot 5$ & 30 & $3 \cdot 4$ & $3 \cdot 4$ & 375 & $3 \cdot 25$ & $3 \cdot 25$ & $4 \cdot 25$ & $4 \cdot 25$ & \\
\hline Major diameter orbit & 1.0 & $1 \cdot 2$ & 1.5 & $1 \cdot 5$ & 1.75 & 1.5 & $1 \cdot \sqrt{5}$ & 20 & $2 \cdot 0$ & 20 \\
\hline Ch.1. (larger)... & 755 & 975 & $10 \cdot 75$ & 1075 & $11 \cdot 5$ & $11 \cdot 4$ & .. & $17 \cdot 0$ & . & $17 \cdot 75$ \\
\hline Ch.l. (smaller) & $7 \cdot 5$ & 975 & $10 \cdot 75$ & $10 \cdot 75$ & 11.5 & 11.0 & .. & $16 \cdot 25$ & .. & .. \\
\hline $\left.\begin{array}{c}\text { Lower bord. propus } \\
\text { (larger) .............. }\end{array}\right\}$ & $4 \cdot 0$ & $5 \cdot 1$ & $5 \cdot 75$ & $5 \cdot 75$ & 6.5 & $6 \cdot 1$ & .. & $9 \cdot 5$ & . & $10 \cdot 0$ \\
\hline $\left.\begin{array}{c}\text { Lower bord. propus } \\
\text { (smaller) } \ldots \ldots \ldots \ldots \ldots\end{array}\right\}$ & 4.0 & $5 \cdot 1$ & $5 \cdot 75$ & 5.75 & 65 & $5 \cdot 8$ & . & $9 \cdot 0$ & & \\
\hline Propus h. (larger) … & 1.5 & 1.9 & 20 & $2 \cdot 0$ & $2 \cdot 3$ & $2 \cdot 8$ & $\ldots$ & 4.25 & & 4.25 \\
\hline (smaller) & 1.5 & 1.9 & $2 \cdot 0$ & $2 \cdot 0$ & $2 \cdot 3$ & $2 \cdot 25$ & & $3 \cdot 25$ & & \\
\hline Fronto-orb. b. $\div \mathrm{C} . \mathrm{b}$ & 72 & 71 & 69 & $6 \pi$ & 67 & 69 & 67 & 66 & 62 & 65 \\
\hline$\div \mathrm{C} . \mathrm{b}$ & 36 & 35 & .35 & 34 & 35 & 33 & $\cdot 32$ & .33 & -30 & 33 \\
\hline Ch.l. (larger) $\div$ c.b. & 1.50 & 1.60 & $1 \cdot 54$ & $1 \cdot 54$ & 1.53 & $1 \cdot 69$ & . & $2 \cdot 00$ & .. & 1.92 \\
\hline $\begin{array}{l}\text { Number: of side-lobes, } \\
\text { counting from behind, } \\
\text { which are spiniform }\end{array}$ & 3 & 3 & 3 & 4 & 1 & 1 on left & 2 & 0 & 1 & 1 \\
\hline $\left.\begin{array}{r}\text { Condition of the two } \\
\text { prominences on imer } \\
\text { angle of wrist }\end{array}\right\}$ & Spines & Spines & Spines & Spines & Spines & Blunt & Teeth & Blunt & “ & $\left|\begin{array}{c}\text { Blunt } \\
\text { tubercles }\end{array}\right|$ \\
\hline Larger cheliped " & Left & Right & Left & Left & Right & Left & Left & Left & . & Left \\
\hline
\end{tabular}

The new species has affinities with several other species of Chlorodopsis. From $C$. areolata it can be distinguished $(a)$ by the type of granulation of the carapace and more particularly of the anterior half, for $C$. areolata has a regular covering of larger pearly granules which are rounded and of similar size in anterior and posterior regions alike; $(b)$ by the absence of the coat of very short fur from dorsal and ventral surfaces of the carapace and from the exposed surface of the external maxillipedes, chelipeds, and walking-legs; (c) by the scattered arrangement of the less numerous long setæ fringing the walking-legs, not hiding the dorsal armature of the latter-this contrasts with the dense close fringe in $C$. areolata; $(d)$ by a few differences in the areolation, thus the areolæ $2 \mathrm{~F}$ have a much more irregular appearance than in C. areolata, where they are rounded and evenly granular; the anterior narrow portion of $3 \mathbf{M}$ extends forward between the posterior borders of the pair $2 \mathrm{~F} ; 3 \mathrm{M}$ has less tendency to be tripartite; $(e)$ by the wider orbital hiatus and less extent to which it is filled by the basal joint of the antenna; $\left(f^{\prime}\right)$ by the armature of the dorsal margin of the three distal joints of the walking-legs, which makes some approach to that of $C$. spinipes-that of C. areolata is hidden by the fringe of setæ, and when the latter is removed is found to be reduced to a granulation in carpopodite and propodite, and entirely absent from dorsal edge of dactylopodite.

The new species may be distinguished from $C$. spintpes and $C$. wood-masoni (a) by the continuation of the areolation over the posterior portion of the 
carapace, though here the grooves between the areolæe are shallower than in the anterior part; $(b)$ by the longitudinal division of areolæ $2 \mathrm{M}$; $(c)$ by the less spiniform character of the armature on the antero-lateral regions of the carapace and the frontal margin ; $(d)$ the tubercles of the chelipeds are not spiniform as in C. spinipes, but are much as in Alcock's figure (Alcock, 1899 (3), Pl. 37. fig. 7) of C. wood-masoni, though less numerous on the larger hand; (e) the hands of the $q$ are subequal in C. arabica and the tubercles of their outer surfaces arranged in more definitely separated straight lines (see figs.); $(f)$ the armature of the dorsal margin of the carpopodite and propodite of the walking-legs is less spiniform than in $C$. spinipes (Pl. 43. figs. $3 a-3 d$ ), more as in Alcock's figure of $C$. wood-masoni. It will be noted that in $(d)$ and $(f) C$. wood-masoni differs from $C$. spinipes in the direction of the new species. Characters in which the new species approaches $C$. spinipes and C. wood-masoni include the type of granulation of the anterior portion of the carapace, the arrangement of the setre of the walking-legs, and the almost naked character of the carapace.

An interesting character in all species of Chlorodopsis is the form and relation of the basal antennal joint. In this, which has been described above, the new species differs a good deal from both $C$. areolata and $C$. spinipes (A. Milne-Edwards, 1873 (1), pl. 8. figs. $8 \& 6 a$ ), and has much the same appearance as in three specimens of $C$. pilumnoides from Ceylon which $I$ have before me (recorded by Laurie, 1906, p. 406).

The new species fal!s under section I. of Alcock's key to the Indian species of Chlorodopsis (Alcock, 1898, p. 165), becoming thus associated wilh C. areolata, from which it is distinguished as above.

Type specimens are in the British Museum.

46. Chlorodopsis spinipes (Heller, 1861). (Plate 43. figs. 3a-3d.) See Alcock, 1898, p. 169.

Chlorodopsis spinipes, Nobili, 1906, p. 270.

? Chlorodopsis wood-masoni, Alcock, 1898, p. 170, and 1899 (3), pl. 37. fig. 7.

Localities. Station V. B, $2 \delta[213,214], 1 q$ [215]; Station V. (), $1 \delta$ [216], 2 ㅇ $[217,218]$; Station V. D, 5 o [219-223], 1 ㅇ [224]; Station V. E, 1 q [225]; Station VII. D, 1 q [226].

Remarks. Except as regards the denticulation of the frontal margin, all the specimens fall fairly well under Alcock's description of C. spinipes.

One may note in particular :-

(a) In all cases the first tooth of the antero-lateral border of the carapace is much reduced as compared with those following it. This is the case in C. spinipes.

(b) In one example, specimen 226 , there is a minute spinule about halfway along the posterior border of the second antero-lateral spine of each side; this is absent in the other examples, where the condition is as in C. spinipes. 
(c) The spines on the walking-legs are more pronounced than in Alcock's figure of $C$. wood-masoni.

(d) The armature of the wrist and hand is markedly acicular, giving an appearance very different from the tubercles figured by Alcock for $C$. woodmasoni; in the case, however, of the ovigerous female, specimen 218 , the condition of the right cheliped makes a decided approach to Alcock's figure just named.

So far then the present specimens fall without doubt under $C$. spinipes in spite of $(b)$ and $(d)$ above, but they agree with $C$. wood-masoni in the denticulate character of the frontal margin. In this latter character they differ a good deal among themselves, but Alcock's figure of C. wood-masoni gives a very fair idea of the frontal condition in some of them. It appears doubtful whether Heller's figure of $C$. spinipes is intended to convey any different impression.

The following is the condition in each of the present specimens :-

\begin{tabular}{|c|c|c|c|c|c|}
\hline $\begin{array}{l}\text { No. of } \\
\text { specimen. }\end{array}$ & Sex. & C.l. & $\begin{array}{l}\text { Number of } \\
\text { denticles on } \\
\text { left inner lobe } \\
\text { of front. }\end{array}$ & $\begin{array}{c}\text { Number of } \\
\text { denticles on } \\
\text { right inner lobe } \\
\text { of front. }\end{array}$ & $\begin{array}{l}\text { Enlarged denticles of inner } \\
\text { frontal lobes; the numbers } \\
\text { are from inner end. } \\
\text { (Outermost denticles excluded.) }\end{array}$ \\
\hline 219. & $\sigma^{*}$ & $\operatorname{mm}_{3 \cdot 25}$ & 23 & 23 & $\left\{\begin{array}{l}2 \mathrm{nd}, 3 \mathrm{rd}, 4 \mathrm{th}, \text { and } 5 \text { th on each lobe } \\
\text { (1st is small on right and very }\end{array}\right.$ \\
\hline 220 . & o & 3.25 & 22 & 22 & $\left\{\begin{array}{l}\text { 2nd, 3rd, and 4th on right. } \\
1 \text { st, } 2 \text { nd, and 3rd on left. } \\
\text { 2nd and 3rd on each. }\end{array}\right.$ \\
\hline 224. & 우 & 3.75 & $4+?+5$ & $6+?+5$ & $\left\{\begin{array}{l}\text { (Denticles obsolescent on middle } \\
\text { of each lobe.) }\end{array}\right.$ \\
\hline $\begin{array}{l}215 . \\
221 .\end{array}$ & $\underset{\substack{\text { qovig. } \\
0}}{0}$ & $\begin{array}{l}4 \cdot 25 \\
4 \cdot 5\end{array}$ & $\begin{array}{l}17 \\
14\end{array}$ & $\begin{array}{l}17 \\
13\end{array}$ & $\begin{array}{l}\text { lst, 2nd, and 3rd on each, } \\
\text { None enlarged. }\end{array}$ \\
\hline 217. & 우 & $5 \cdot 0$ & 16 & 16 & $\left\{\begin{array}{l}\text { 2nd and 3rd on right. } \\
\text { 2nd, 3rd and } 4 \text { th on left. }\end{array}\right.$ \\
\hline $\begin{array}{l}218 . \\
216 .\end{array}$ & $\frac{c \text { ovig. }}{d}$ & $\begin{array}{l}5 \cdot 0 \\
5 \cdot 0\end{array}$ & $\begin{array}{l}12 \\
11\end{array}$ & $\begin{array}{l}12 \\
11\end{array}$ & $\begin{array}{l}\text { lst on each. } \\
\text { lat on each. }\end{array}$ \\
\hline 222. & $\delta$ & $5 \cdot 25$ & 16 & 14 & $\left\{\begin{array}{l}\text { 2nd and 3rd on right. } \\
\text { 2nd 3rd and 4th on left. }\end{array}\right.$ \\
\hline $\begin{array}{l}223 . \\
213 .\end{array}$ & $d$ & $\begin{array}{l}5 \cdot 5 \\
5 \cdot 5\end{array}$ & $\begin{array}{l}18 \\
13\end{array}$ & $\begin{array}{l}18 \\
13\end{array}$ & $\begin{array}{l}\text { 2nd and 3rd on each. } \\
\text { 1st and 2nd on each. }\end{array}$ \\
\hline 225. & 우 & $6 \cdot 25$ & 8 & 10 & $\left\{\begin{array}{l}\text { 1st, } 2 \text { nd, 5th, and } 7 \text { th on right. } \\
\text { All on left }\end{array}\right.$ \\
\hline $\begin{array}{l}226 . \\
214 .\end{array}$ & $\frac{9}{0}$ & $\begin{array}{l}6 \cdot 25 \\
7 \cdot 0\end{array}$ & $\begin{array}{l}6 \\
8\end{array}$ & $\begin{array}{r}7 \\
11\end{array}$ & $\begin{array}{l}\text { All. } \\
\text { All, particularly lst on each. }\end{array}$ \\
\hline
\end{tabular}

The outermost tooth of the inner frontal lobe, and in some cases more than one tooth in this position, is also enlarged. There is a similarly enlarged tooth on the small outer frontal lobe to the inner side of the much larger terminal tooth. 
It will be noted that the number of teeth is very variable. The larger teeth are of an order of size easily made out under a hand lens which magnifies 6 diameters.

To sum up :-The specimens fall under C. spinipes. C. wood-masoni has, however, a frontal condition difficult to distinguish from that of $C$. spinipes. The presence of the minute accessory spinule in specimen 226 and the character of the right chela in specimen 218 should be noted as some approach to $C$. wood-masoni. One could hardly perhaps unite the two species on the data supplied by the present specimens, but on the other hand Nobili's remark is to be kept in mind to the effect that examples examined by him throw grave doubt upon their specific distinction.

Genus Crmo, de Haan, 1833.

47. (ymo andreossy (Audouin et Savigny, 1826). See Alcock, 1898, p. 173.

Cymo Andreossyi, Nobili, 1906, p. 271.

Cymo Andreossyi, Nobili, 1907, p. 129.

Cymo andreossyi, Laurie, 1906, p. 406. (A single specimen, which belongs to var. melanodactylus.)

Cymo andreossyi, Stimpson, 1907, p. 60.

Localities. Station I. J, 1 o [227] ; Station V. E, 1 o [228], 3 q [229231]; Station VIII. D, 4 \& [232-235], 2 \% [236, 237].

Remarks. $\delta 227$ is apparently adult, C.l. $18 \mathrm{~mm}$. , C.b. $19 \mathrm{~mm}$; all the others are small, C.1. from $3 \cdot 25$ to $6 \mathrm{~mm}$.

The small $q$ specimens 229 and 236 , with C.l. 6 and $5.5 \mathrm{~mm}$. respectively, though not ovigerous, appear to be adult, whereas another specimen with C.l. only $4 \mathrm{~mm}$. is immature.

The frontal breadth of the large specimens agrees with Alcock's description, " $\frac{2}{5}$ the greatest breadth of the carapace," if it be taken to include the inner supraorbital angles; but if the latter be excluded then the front is only -33 the greatest breadth of the carapace.

In all the specimens the granules lose their sharpish character on the lower part of the outer surface of the larger hand, becoming here more rounded and pearl-like.

In the large specimen 227 the granules on the upper part of the outer surface of the wrist and hand are sharpish conical; in the other and smaller specimens the granules in this position are sharper, and in some specimens some of them are almost spines.

The areolation of the carapace is less clearly seen in the small specimens.

The present examples do not include any having the brown fingers of var. melanodactylus, de Haan, which variety is, however, also recorded from the Red Sea. For the synonomy of var. melanodactylus, see Alcock, 1898, 1. 174 ; 
later records have been made by Nobili, 1906, p. 271, and Nobili, 1907, p. 129 ; see also Cymo melanodactylus, Stimpson, 1907, p. 59. I take this opportunity of pointing out that the specimen recorded from Ceylon by Laurie, 1906, p. 406, under the name of Cymo andreossyi also belongs to var. melanodactylus.

Nobili found transitional conditions of finger-coloration both in Red Sea specimens and in examples from the Persian Gulf.

Genus Pilumnus, Leach, 1815.

48. Pilumud Propinquus, Nobili, 1905. See Nobili, 1907, p. 140.

Pilumnus propinquas, Nobili, 1906, p. 277, pl. 9. fig. 7 .

Localities. Station VII. B, 2 o $[238,239], 2$ \& [240, 241]; Station X., $1 \delta[242], 2$ \& $[243,244]$; no locality given, $1 \delta[245]$.

Remarks. $\delta$ C.Is. are 5, 6, 6.75, and $8.75 \mathrm{~mm}$. respectively; 우 C.ls. $4 \cdot 5$, $4 \cdot 75,5 \cdot 25$, and $6 \mathrm{~mm}$. respectively. The largest $\delta$ (245) has C.b. $12 \mathrm{~mm}$, so that C.b. $\div$ C.J. $=1.37$; frontal b. of same specimen $3.75 \mathrm{~mm}$. without the inner orbital angles and $5 \mathrm{~mm}$. if the latter be included; distance between outer orbital angles $8.75 \mathrm{~mm}$. These measurements agree very well with those of the specimen described by Nobili.

In the present specimens the armature of the chelipeds and walking-legs is less emphasized than in Nobili's description of forms from the Persian Gulf: thus $(a)$ they have in general on the meropodites of the walking-legs only the distal spine of the upper border and this is in a few instances replaced by a blunt tubercle; Nobili calls attention to the variation in the degree of spininess of the meropodites in his forms from the Persian Gulf and notes that the meropodites were without spines in his Red Sea (Djibouti) examples; (b) the tubercles of the wrist and upper part of the outer surface of the hand are as a whole conical and pointed; some of them, indeed, more particularly on the smaller hand, are elongated, but very few, and in some specimens none, could be called spiniform; (c) in all the subhepatic tooth is present, but it tends to be tubercular rather than spiniform; $(d)$ none of the spines is blackish.

In all except the $q 241$ it is the right hand which is the more massive.

$$
\text { Genus Actumus, Dana, } 1851 .
$$

49. Actumnus setifer (de Haan, 1835), var. tomentosus, Dana, 1852. See Alcock, 1898, p. 202.

Actumnus setifer, var. tomentosus, Laurie, 1906, p. 408. Actumnus tomentosus, Alcock, loc. cit. Actumnas tomentosus, Nobili, 1907, p. 132.

Localities. Station V. D, $1 \delta[246], 4 q[247-250]$; Station VII. B, 1 우 [251]; Station X., 1 \& [252]; no locality given, labelled “Trials I.," 2 q 
$[253,254]$; no locality given, labelled "Sponge Inhabiters, 11 Jan., 1905," 1 i $[255]$.

Remarks. The only $\delta$ in the above series has C.l. $5.75 \mathrm{~mm}$. Specimens 249,251 , and 252 , though all ovigerous, are of very different size, (.1. 4, 6, and $11 \mathrm{~mm}$. respectively. Specimens 255,254 , and 253 are not ovigerous, but apparently adult, C.l. respectively $7 \cdot 5,8$, and $8.5 \mathrm{~mm}$.

250 and $\$ 254$ have each a parasitic Sacculina attached to the abdomen, C.l. $4 \cdot 5$ and $8 \mathrm{~mm}$. respectively.

Regarding the position of tomentosus as a variety of $A$. setifer, see Miers, 1884, p. 225, and Laurie, loc. cit.

A. setifer has not been hitherto recorded from the Red Sea.

50. Actumnus bonnieri, Nolili, 1905. See Nobili, 1907, p. 132, pl. 6. fig. 32 .

Actumnus Bonnieri, Nobili, loc. cit.

Actumnus Bonnieri, Nobili, 1906, p. 285.

Actumnus bonnieri, Laurie, 1906, p. 409.

Actumnus bannieri, Rathbun, 1911, p. 232.

Localities. Station VIII. (,, $1 \delta$ [256]; Station X., 1 q ovig. [257].

Remarks. $q$ ovig. 257 has C.1. $9 \cdot 25 \mathrm{~mm}$. ; $\delta 256$ has C.l. $7.5 \mathrm{~mm}$.

Genus Heteropanope, Stimpson, 1859.

51. Heteropanope vauquelini (Audouin et Savigny, 1826). See Heller, 1861, p. 344 .

Pilumnus Vauquelini, Heller, loc. cit.

Heteropanope Vauquelini, Nobili, 1906, p. 285.

Localities. Station I. B, 7 б [258-264], 5 q [265-269]; Station I. C, $4 \delta$ [270-273]; 9 \& [274-282]; Station I. D, 1 o [283], 10 우 [284-293]; Station I. E, 3 ๙ [294-296], 10 क [297-306] ; Station I. H, 1 ठ [307]; no locality given, labelled "Sponge Inhabiters, 11 Jan., 1905," 2 đ $[308,309]$, 3 ㅇ [310-312]; no locality given, labelled "Trials I.," $1 \delta^{\pi}$ [313], 3 o [314-316].

Remarks. There are 59 specimens in all. C.l. ranges in $q$ from $2 \cdot 75$ to $7.25 \mathrm{~mm}$. and in $\delta$ from 2.75 to $8.25 \mathrm{~mm}$. None of the $q$ specimens are ovigerous, but all having C.l. $4 \mathrm{~mm}$. or over, with the exception of two, have an aduli appearance. The largest $\delta$ has $0.1 .8 .25 \mathrm{~mm}$. and C.b. $11.5 \mathrm{~mm}$, so that C.l. $\times$ C.b. $=\cdot 72$.

Of 50 specimens 35 (12 $\delta$ and $23 q$ ) have the right hand, and 15 ( 78 and $8 q$ ) the left hand, the more massive. Heller also found that in his examples it was generally the right hand which was the larger.

The specimens agree very fairly with Heller's description (loc. cit.) and Savigny's figure (Savigny, 1826, pl. 5. fig. 3). There is a good deal of variation in the distribution of hair on the carapace, a point noted also by 
Nobili. The lower border of the orbit is granular or crenulated in all the specimens, which was the case in Nobili's examples.

The carapace of $q 284$ is asymmotricul and abnormal in regard to its antero-lateral teeth; on its left side the second tooth is reduced to a slender spine and on its right side only two teeth are present.

Genus Trapezta, Latreille, 1825.

52. Trapezia cymodoce (Herbst, 1801). See Alcock, 1898, p. 219.

Trapezia cymodoce, Nobili, 1906, p. 292.

Trapezia cymodoce, Laurie, 1906, p. 410.

Grapsillus cymodvce, Rathbun, 1906, p. 865, pl. 11. fig. 6.

Trapezia cymodoce, Rathbun, 1911, p. 234 .

Localities. Station I. D, $1 \delta$ [317]; Station V. D, 1 \& juv. [318]; Station V.E, 1 \% [319], 2 \& [320-321] ; Station VII. B, 3 б [432-434]; Station VII. D, 16 ठ $[322-335,359,360], 15$ \& $[336-349,361]$ (9 ovig.); Station IX. A, 1 ठ [362] ; no locality given, 3 o [356-358], 9 q [350$.355,363-365]$ (4 ovig.).

Remarks. In all 52 specimens, except only the large $\delta 360$, the outer division of the frontal lobe of each side is seen to be crenulated when examined through a lens.

In most of the specimens a transverse line of rounded red spots is more or dess evident on the carapace when carefully looked for. In no case is this

Fig. 2.

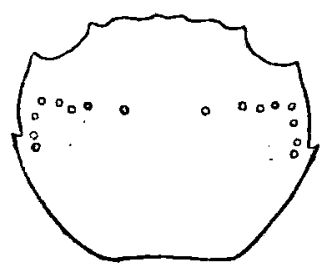

Trapexia cymodoce. Dorsal view to show position of line of spots.

line obvious to the naked eye at a casual glance, but on a more careful examination, especially with a hand-lens, it can be made out very completely in seventeen specimens (in ten of which, however, the colour appears to have faded, leaving the spots whitish), incompletely in seven, an inner pair of spots only in twelve, and not seen in sixteen. Of those specimens in which it is not seen twelve are quite small; other small specimens, however, have it present. It appears as if the presence of the complete line is normal in the living condition and that the other less complete conditions represent stages in fading of spirit-specimens. Even in some of those described above as not showing it, traces were discovered on careful examination under a Zeiss 
binocular dissecting microscope. The line under consideration commences on either side just inside the lateral epibranchial spine and runs forwards to curve inward halfway between this and the outer orbital tooth, then running inward and slightly backward to terminate in a spot somewhat larger than the others well to the side of the middle line. Thus the whole line is divided into right and left halves, which are symmetrical. The spots are closer together on the branchial portions of the line.

The growth-changes in this species are considerable, as the following table will illustrate: -

\begin{tabular}{|c|c|c|c|c|c|c|c|c|}
\hline $\begin{array}{l}\text { No. of } \\
\text { specimen. }\end{array}$ & Sex. & C.l. & c.b. & $\begin{array}{l}\text { C.b. } \\
\text { C.1. }\end{array}$ & $\begin{array}{c}\text { Antero-lateral } \\
\text { borders of } \\
\text { carapace. }\end{array}$ & $\begin{array}{l}\text { Condition of } \\
\text { Iateral } \\
\text { epibranchial } \\
\text { tooth. }\end{array}$ & $\begin{array}{l}\text { Condition of } \\
\text { teeth on anterior } \\
\text { border of merus } \\
\text { of cheliped. }\end{array}$ & $\begin{array}{l}\text { Condition of } \\
\text { teeth on anterior } \\
\text { border of carpus } \\
\text { of cheliped. }\end{array}$ \\
\hline 362. & 8 & $\frac{\operatorname{mm}}{2 \cdot 8}$ & $\mathrm{~mm}$. & .. & $\begin{array}{c}\text { Anteriorly di- } \\
\text { vergent. }\end{array}$ & Spiniform. & $\begin{array}{c}\text { Spiniform, pro- } \\
\text { curved. }\end{array}$ & Spiniform. \\
\hline 363. & 오 & 3.5 & .. & .. & $"$ & , & $"$ & Acute. \\
\hline 364. & 우 ovig. & 6.0 & .. & .. & A pprox parallel. & " & $\begin{array}{l}\text { Acute, pro- } \\
\text { curved. }\end{array}$ & $"$ \\
\hline 365. & 우 & $7 \cdot 75$ & .. & . & $\begin{array}{c}\text { Anteriorly con- } \\
\text { rergent. }\end{array}$ & " & $"$ & $"$ \\
\hline 359. & $\sigma^{\circ}$ & 1075 & $12 \cdot 5$ & $1 \cdot 16$ & $"$ & Blunt. & $\begin{array}{l}\text { Squarish, pro- } \\
\text { curved. }\end{array}$ & Blunt. \\
\hline 360. & $\sigma^{*}$ & $13 \cdot 0$ & $15 \cdot 5$ & $1 \cdot 19$ & " & Notch. & $\begin{array}{c}\text { Blunt, a little } \\
\text { procuved. }\end{array}$ & Absent. \\
\hline 361. & q ovig. & $13 \cdot 0$ & $17 \cdot 0$ & $1 \cdot 31$ & $"$ & Obscure notch. & $"$ & $"$ \\
\hline
\end{tabular}

During growth the main changes are (1) from spiniform armature to an armature which is more blunt and less conspicuous ; (2) from anteriorly divergent to anteriorly convergent antero-lateral borders of the carapace.

The large difference in size between the two ovigerous females should be noted. The smaller specimen has reached the egg-beariag stage, while still showing the general characters appropriate to a comparatively early growthstage.

The different ratio between carapace length and breadth in the large males and the large female will be noted, due to the greater relative width of carapace in the female.

Out of seventeen $\delta$ specimens with C.l. ranging from 6 to $15 \mathrm{~mm}$., eleven have the left and six the right hand the more massive.

Var. edentula.-I suggested this name for alspecimen frombeylon (loc. cit.), in which the lateral epibranchial tooth was absent and the hand naked. The former character appears of doubtful value, in view of the considerable 
changes during growth indicated by the above table; but specimens 359365 of the present collection have also a naked hand. (As the specimens happen to make a convenient series in regard to size $I$ have used them for the table above).

$52 a$. Trapezia cymonoce, var. Maculata (Macleay, 1838). See Alcock. 1898, p. 221.

Trapezia maculata, Alcock, loc. cit.

Trapezia maculata, Nobili, 1906, p. 293.

Trapezia maeulata, Laurie, 1906, p. 410.

Trapezia maculata, Stimpson, 1907, p. 73.

Grapsillus maculatus, Rathbun, 1906, p. 865.

Trapezia cymodoce maculata, Rathbun, 1911, p. 235.

Locality. Station VII. D, 1 ठ [366], 1 \& ovig. [367].

Remarks. q ovig. 367 has C.1. $14.5 \mathrm{~mm}$., greatest C.b., a line joining points of union of antero-lateral and postero-lateral borders, $17.5 \mathrm{~mm}$., Ch.l. $28 \mathrm{~mm}$, merus l. measured from most proximal to most distal point of lower surface $9 \mathrm{~mm}$.; O.b. across region of outer orbital teeth $15 \mathrm{~mm}$., so that the antero-lateral borders, which are a little convex, slope inwards anteriorly. The outer angle of the orbit is pointed. The inner angle of the lower margin of the orbit bears a sharp tooth. The boundary between the antero-lateral and postero-lateral borders of the carapace is marked by a blunt tubercle. The inner angle of the wrist bears a blunt pointed tubercle in place of a spine. There are 118 red spots visible in a dorsal view of the carapace, a few of them tending to run together in pairs on the lateral portions of the gastric regions.

Specimen o 366 is small, C.l. $5 \mathrm{~mm}$., C.b. measured by a line joining points of union of antero-lateral and postero-lateral borders $6 \mathrm{~mm}$; a line unitiug the outer orljital teeth $6.25 \mathrm{~mm}$. It differs from the o ovig. 367 in (a) the sharp spiniform character of the denticles marking the outer angle of the orbit, the inner angle of the lower margin of the orbit, the boundary between the antero-lateral and the postero-lateral borders of the carapace, the inner border of the arm and the inner border of the wrist; $(b)$ the almost straight character of the frontal border, the teeth being very little marked; (c) the antero-lateral borders of the carapace slope a little outward anteriorly; (d) the number of red spots visible on the carapace in dorsal view is small, namely, twenty-eight.

The points mentioned above in regard to the small $\delta$ are probably marks of youth. The specimen bears a close resemblance to a $q$ of the same size and a rather larger $\delta$ (C.l. $7 \mathrm{~mm}$.), both from Ceylon, which I have before me (Laurie, loc. cit.). The Ceylon $\delta$, however, is somewhat intermediate in the character of its front between the two present specimens and 
has 48 red spots visible in a dorsal view of the carapace; the Ceylon $q$ has also 48 spots approximately, but it is difficult to count the number accurately, as they are in a very faded condition.

Genus Tetralia, Dana, 1851.

53. Tetralia alaberrima (Herbst, 1790). See Alcock, 1898, p. 223.

Tetralia glaberrima, Nobili, 1906, p. 294.

Tetralia glaberrima, Nobili, 1907, p. 143.

Tetralia glaberrima, Stimpson, 1907, p. 74.

Localities. Station III., 1 q ovig. [368]; Station V. E, 1 o ovig. [369]; Station VII. B, 1 ovig. [370]; Station VII. D, $2 \delta$ probably adult [371$372], 3$ o ovig. [374-376].

Remarks. An ovigerous $q$ has C.1. $9 \mathrm{~mm}$. and C.b. $10.5 \mathrm{~mm}$.

In two of the females the left cheliped, and in the other six specimens the right cheliped, is the larger.

\section{Family GONEPLACIDE.}

Genus Libystes, A. Milne-Edwards., 1867.

54. Limystes Nitrous, A. M.-El $*$., 1867. See A. M.-Edw. 1868, p. 83, pl. 20. figs. 5-7.

Lybystes nitidus, Nobili, 1906, p. 297.

Localities. Station VI. 1 ठ [377]; Station VIII. A, 1 б $[378], 3 q$ [379-381].

Remarks.

\begin{tabular}{|c|c|c|c|c|c|}
\hline C.l. & $\begin{array}{c}\text { } 379 . \\
5.75\end{array}$ & $\begin{array}{c}q 380 . \\
7.25\end{array}$ & $\begin{array}{c}\text { 오 } 381 . \\
775\end{array}$ & $\begin{array}{c}\sigma 378 . \\
4.0\end{array}$ & $\begin{array}{c}0377 \\
7 \cdot 75 \mathrm{~mm}\end{array}$ \\
\hline c.b....... & $8 \cdot 5$ & $11 \cdot 25$ & $12 \cdot 0$ & $6 \cdot 0$ & $13 \cdot 0 \mathrm{~mm}$. \\
\hline C.b. $\div$ C.l. & $I \cdot 48$ & $1 \cdot 55$ & 155 & $1 \cdot 50$ & $1 \cdot 68$ \\
\hline Lower bord. propus right cheliped . . & $7 \cdot 25$ & $9 \cdot 75$ & $10 \cdot 25$ & $5 \cdot 0$ & $12 \cdot 0 \mathrm{~mm}$. \\
\hline Height propus right cheliped & $2 \cdot 5$ & $4: 0$ & 35 & $1 \cdot 75$ & $3.75 \mathrm{~mm}$. \\
\hline Lower bord. propus left cheliped. & $7 \cdot 0$ & $9 \cdot 0$ & $9 \cdot 5$ & $5 \cdot 0$ & $12 \cdot 0 \mathrm{~mm}$. \\
\hline Height propus left cheliped. & $2 \cdot 0$ & $2 \cdot 5$ & $2 \cdot 5$ & 1.25 & $3.75 \mathrm{~m}$ \\
\hline
\end{tabular}

All the specimens have a uniformly fine granulation on the antero-lateral margin of the carapace ; there are no denticles on this margin such as Nobili describes for his small $q$ (C.l. $7.5 \mathrm{~mm}$.) from Djibouti, and looked upon by him as a condition of youth.

In the larger $\delta$ specimen the hands are similar. In the smaller $\delta$ and in the $q$ specimens there is a good deal of difference between the hands, the right being in each case much more massive than the left, though not much longer. In specimens 380 and 381 the fixed finger of the less massive left hand bears on its distal half 3 spiniform teeth, of which the middle one is the largest, in the small of 379 the proximal of the three teeth is absent. In 
the small $q 379$ the larger right band makes an approach to Milne-Edwards's fig. 7, the lower border being slightly concave near the base of the fingers and the fingers not markedly hooked at tips; in the more slender left hand of the same specimen the ends of the fingers are strongly curved towards each other, which condition occurs also in both hands of all the other examples.

It will be noted, as pointed out above, that though in the smaller $\delta$ one hand is more massive than the other, yet in the larger $\delta$ the two hands are equally massive.

\section{Genus Litocheira, Kinahan, 1856.}

Original orthngraphy Litocheira, not Litochira ; see Kinahan, 1856, p. 116.

55. Lutocheira integra (Miers, 1884). (Plate 45. fig. 2.) See Alcock, 1900, p. 314.

Litochira integra, Alcock, loc. cit.

Carcinoplax integra, Miers, 1884, p. 543.

Localities. Station V. A, 1 б [382], 1 \& ovig. [383]; Station V. B, 1 б [384], 2 우 $[385,386]$.

Remarks. The specimens agree with Alcock's description of the genus and species. Miers's figure (1884, pl. 48. fig. C) would have given a good idea of the present examples if the fringing setæ, even of the front, had been made longer. Many of the very long fine setæ which fringe the front, the antero-lateral borders, the chelipeds, and the walking-legs are in the present specimens more than one-half as long as the carapace, and give a very beautifal appearance to the creatures.

I give an anterior view of the front with the setæ removed, which is "turned down and distinctly arched"-a character of the genus Litocheira, to which Alcock calls attention.

Miers gives dimensions of his $q$ specimen as C.l. $4 \mathrm{~mm}$. and C.b. $5 \mathrm{~mm}$, but this may be a slip, as his figure, drawn to scale, gives ratio as 4 to 6 . De Man (1888, p. 93) cites a $\delta$ as having C.I. 7.75 and C.b. $1025 \mathrm{~mm}$. Alcock gives a $q$ as $6 \times 9$. The measurements in the present specimens are as follows:-

\begin{tabular}{|c|c|c|c|c|c|}
\hline o.l. & $\begin{array}{c}+385 . \\
2.5\end{array}$ & $\begin{array}{c}\text { of ov. } 386 . \\
40\end{array}$ & $\begin{array}{c}\text { q ov. } 383 . \\
4: 2\end{array}$ & $\begin{array}{c}\delta 382 . \\
2 \cdot 75\end{array}$ & $\begin{array}{c}\text { d } 384 . \\
3.75 \mathrm{~mm} .\end{array}$ \\
\hline C.b. & 3.5 & 5.75 & $6 \cdot 1$ & $4 \cdot 0$ & $5.25 \mathrm{~mm}$ \\
\hline C.l. $\div$ C.b. ...... & .71 & $\cdot 70$ & .69 & 69 & 71 \\
\hline
\end{tabular}

In the ovigerous female 383 the breadth of the frontal margin is $2 \mathrm{~mm}$., and a line uniting the external angles of the orbits measures $4.25 \mathrm{~mm}$.

Both genus and species are new to the Red Sea. 


\section{Family PINNOTHERID $\mathbb{E}$.}

Genus Ostracotheres, $H$. Milne-Edwards, 1853.

Original orthography Ostracotheres, not Ostracoteres; see H. Milne-Edwards, 1853, p. 219.

56. Ostracotheres cynthi e, Nobili, 1905. (Pl. 45. figs. 3-3b.) See Nobili, 1906, p. 301.

Ostracoteres cynthice, Nobili, loc. cit.

Locality. No locality given, $1 \varnothing$ [390].

Remarks. After characterising the species from a $q$ example by pointing out that, among other things, its carapace is quadrangular rather than globular and that the dactylus of the last walking-leg is long, flattened, hairy, and has a sinnous margin, Nobili adds that in the $\delta$ the carapace is more rounded and the dactylus of the last walking-leg differs little from those of the others.

In the present specimen the carapace is almost, though not altogether, circular, with the posterior border convex. It is seen under a lens to be faintly pitted and to bear a few scattered very short inconspicuous setæ.

The deflexed anterior obtasely pointed tip of the front is only seen in an anterior view of the animal.

The distal end of the propodite of the third maxillipede differs from Nobili's description and figure, for, instead of being obliquely truncated, it is the same width distally as elsewhere and its distal margin is concave. The form of this appendage is important in species of Ostracotheres.

Fig. 3.

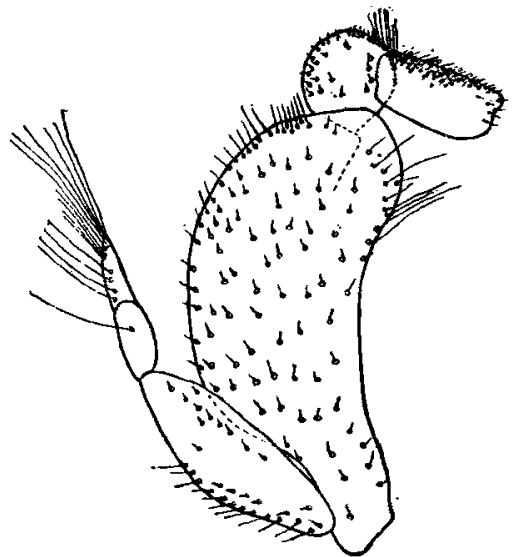

Ostracotheres cynthice. External maxillipede, ơ 390.

Cheliped stout, half as long again as the carapace (1.58 C.l.), a little longer than walking leg 1 (1.07 length of W.L. 1); wrist swollen; hand with lower outer border strongly marked posterioriy, producing a triangular LINN. JOURN,-ZOOLOGY, VOL. XXXI. 
appearance ; the tip of the fixed finger is pointed and curved and lies against the outer side of the more strongly curved tip of the dactylus; dactylus about three-quarters as long again as the upper border of the propus ( 1.71 upper border propus), its tip very strongly curved -at the base of its apposed border is a large triangular tooth and a smaller one on the distal half of the same border corresponding to a similarly placed one on the fixed finger; the fingers meet only at their tips, which cross as above indicated, the considerable gape being occupied by fine downy hairs. The whole cheliped, more particularly the inner surface of the hand, is covered with fine down.

The first three walking-legs are of equal length and each is a little shorter than the cheliped and $1 \cdot 48$ C.I. ; W.L. 4 is shorter $(1 \cdot 3$ C.l.). The dactyli of W.L. 1, 2, and 3 are equal in length $(0.23$ C.1.), that of W.L. 4 is longer $(0.28$ C.l. $)$, but of very similar form.

Some measurements of the specimen are as follows :-C.1. $6 \mathrm{~mm}$; C.b. $6 \mathrm{~mm}$.; Ch.l. $9.5 \mathrm{~mm}$.; lower bord. propus Ch. $1.75 \mathrm{~mm}$.; F.l. $3.1 \mathrm{~mm}$; W.L. 1, 2, and 3 are each $8.9 \mathrm{~mm}$.; W.L. 4 is $7.8 \mathrm{~mm}$.; dactylus l. of W.L. 4 is $1.7 \mathrm{~mm}$.

It will be noted that in Nobili's key of Ostracotheres the place of $O$. cynthice is determined by characters of the $q$; the key is of doubtful value in identifying a $\sigma^{*}$ example.

Nobili does not figure the species, save for a text-figure of part of the third maxillipede (sex not stated).

As Nobili's reference to the $\delta$ is not very precise, and his description and figure of the propodite of the external maxillipede do not agree with mine, it is just possible that the present specimen represents a new species; should this be so, the almost circular carapace and the form of the propodite of the external maxillipede are characters to be noted more especially.

Genus Pinnotheres, Bosc, 1802.

Original orthography Pirnotheres, not Pinnoteres.

57. Pinnotheres pilumnoides, Nobili, 1905. See Nobili, 1906, p. 307, fig. 12.

Pinnoteres pilumnoides, Nobili, loc. cit.

Localities. No locality given, labelled "Trials I., mostly from sponge," 1 i adult non-ovig. [387]; no locality given, labelled "From Holothuria gallensis," 2 \& ovig. [388, 389].

Remarks.

\begin{tabular}{|c|c|c|c|}
\hline Cl. & $\begin{array}{l}\text { ㅇ } 387 . \\
10.0\end{array}$ & $\begin{array}{c}\text { Pov. } 388 . \\
10 \cdot 0\end{array}$ & $\begin{array}{r}\text { 9ov. } 389 . \\
12 \cdot 25 \mathrm{~mm} .\end{array}$ \\
\hline c.b.................. & $11 \cdot 0$ & $11 \cdot 5$ & $14.25 \mathrm{~m}$ \\
\hline Post. bord. O. .......... & $4 \cdot 0$ & $5 \cdot 0$ & $6.0 \mathrm{~m}$ \\
\hline c.l. $\div$ C.b............ & $\cdot 91$ & .87 & .86 \\
\hline Post. bord. C. $\div$ C.b. $\ldots$ & $\cdot 36$ & $\cdot 43$ & $\cdot 42$ \\
\hline
\end{tabular}


It is difficult to give accurate measurements, owing to the slight degree of calcification of the carapace. Those of specimen 387 are the most reliable.

Spocimen 389 carries $714 \mathrm{eggs}$, each having a diameter of about $0.75 \mathrm{~mm}$.

\section{Family OCYPODIDAE.}

Genus Ocypod r, Fabricius, 1798.

Original orthography Ocypode, not Ocypoda; see Miers, 1882, p. 376.

58. Ocypode engrtaca, Gerstïcker, 1856. See Miers, 1882, p. 381, pl. 17. fig. 3 .

Ocypoda agyptiaca, Miers, loc. cit.

Ocypoda agyptiaca, Nobili, 1906, p. 310.

Ocypoda agyptiaca, Nobili, 1907, p. 152.

Locality. Station IX. B, 1 $\delta$, probably adult [3917.

Remarks. C.1. $36 \mathrm{~mm}$. The stridulating organ is composed of 80 ridges in this example.

The outer orbital angles undergo considerable growth-change in this species (see Nobili, 1906, loc. cit.). The text-figure shows their condition in the present specimen, and also an eye-stalk with its characteristically curved terminal style.

Fï. 4.

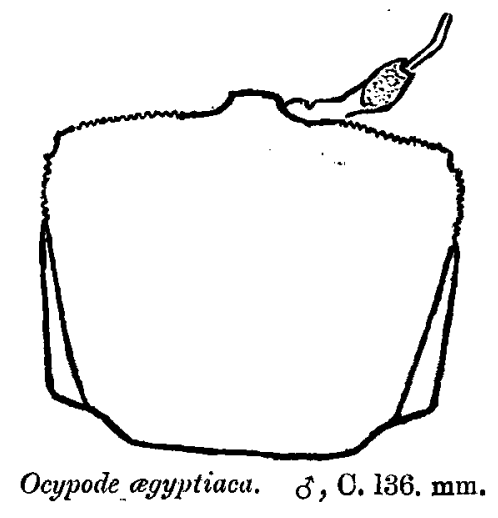

Genus Dotrlla, Stimpson, 1859.

59. Dotilla sulcatia (Forskcil, 1775). See Alcock, 1900, p. 365.

Dotilla affinis, Alcock, loc. cit.; and 1902, pl. 63. fig. 1.

Dotilla salcata, Nobili, 1906, p. 315.

Locality. Station I. B, 9 ๙ $[392-400], 4$ \& [401-404].

Remarks. The present specimens enable me to add further evidence in favour of Nobili's suggestion (Nobili, loc. cit.) that Dotilla affinis, formed in 
1900 by Alcock for four specimens from Aden and the Baluchistan coast, is a synonym of this species.

The characters by which Alcock separates his species from $D$. sulcata are : (1) the absence of the spine from the under surface of the arm ; (2) the presence of a tympanum on the dorsal surface of the merus of the last pair of walking-legs, and (3) the fact that the fingers are shorter than the palm. The condition of each of these characters in my specimens is shown in the following table :-

\begin{tabular}{|c|c|c|c|c|c|c|c|}
\hline $\begin{array}{c}\text { No, of } \\
\text { specimen. }\end{array}$ & Sex. & C.1. & $\begin{array}{l}\text { H.1. (upper } \\
\text { bord.). }\end{array}$ & F.1. & $\frac{\text { H.l. }}{\text { F.1. }}$ & $\begin{array}{l}\text { Meral } \\
\text { spine. }\end{array}$ & 'Tympunum. \\
\hline $\begin{array}{l}401 . \\
402 . \\
403 . \\
404 .\end{array}$ & $\begin{array}{l}q \\
q \\
q \\
q\end{array}$ & $\begin{array}{l}\underset{5.6}{\operatorname{mm}} \\
5.9 \\
6.0 \\
6.5\end{array}$ & $\begin{array}{c}\operatorname{mm} . \\
1.5 \\
1.5 \\
1.5 \\
1.6\end{array}$ & $\begin{array}{r}\mathrm{mm} . \\
3 \cdot 0 \\
3 \cdot 0 \\
3 \cdot 0 \\
3 \cdot 5\end{array}$ & $\begin{array}{l}2 \cdot 00 \\
2 \cdot 00 \\
2 \cdot 00 \\
2 \cdot 19\end{array}$ & $\begin{array}{l}\text { Absent. } \\
\text { Absent. } \\
\text { Absent. } \\
\text { Absent. }\end{array}$ & $\begin{array}{l}\text { [Leg lost.] } \\
\text { Present. } \\
\text { Present. } \\
\text { [Leg lost.] }\end{array}$ \\
\hline & & & & & $\begin{array}{l}\text { Average in } \\
4 \% \mathrm{~s}=2.05\end{array}$ & $\begin{array}{l}\text { Absent } \\
\text { in all. }\end{array}$ & $\begin{array}{l}\text { Present } \\
\text { in both. }\end{array}$ \\
\hline 392. & $d$ & 50 & $2 \cdot 0$ & 30 & $1 \cdot 60$ & Absent. & Present. \\
\hline 393. & $\sigma^{*}$ & $5 \cdot 9$ & $1 \cdot 9$ & $3 \cdot 4$ & $1 \cdot 79$ & Absent. & Absent. \\
\hline 394. & $\sigma^{2}$ & $6 \cdot 0$ & $2 \cdot 1$ & $3 \cdot 2$ & $1 \cdot 52$ & Absent. & $\begin{array}{l}\text { Absent Rt. } \\
\text { [Left lost.] }\end{array}$ \\
\hline 395. & $\delta$ & $6 \cdot 0$ & $2 \cdot 0$ & 35 & $1 \cdot 75$ & Absent. & 'I'race. \\
\hline 396. & $\delta$ & $6 \cdot 0$ & $2 \cdot 0$ & $3 \cdot 2$ & $1 \cdot 60$ & Absent. & Present. \\
\hline 397. & $\delta$ & 6.0 & $2 \cdot 5$ & $3 \cdot 7$ & $1 \cdot 48$ & Absent. & Present. \\
\hline 398. & $\sigma^{\circ}$ & 6.5 & 2.5 & $3 \cdot 8$ & $1 \cdot 52$ & Absent. & Present. \\
\hline 399. & $\sigma^{*}$ & $7 \cdot 0$ & $2 \cdot 8$ & $3 \cdot 9$ & $1 \cdot 39$ & Trace. & Present. \\
\hline 400. & $0^{*}$ & 75 & 30 & $4 \cdot 2$ & $1 \cdot 40$ & Present. & Present. \\
\hline & & & & & $\begin{array}{l}\text { Average in } \\
9 \delta \mathrm{s}=1.55\end{array}$ & $\left.\begin{array}{l}\text { Absent } 7 . \\
\text { Trace 1. } \\
\text { Present } 1 .\end{array}\right\}$ & $\left.\begin{array}{l}\text { Present 6. } \\
\text { Irace 1. } \\
\text { A bsent } 2 .\end{array}\right\}$ \\
\hline
\end{tabular}

It will be noterl from the above table that the most usual condition is for the spine to be absent and the tympanum present, this occurring in six instances (seven if 395 be included); but in one specimen (two if 399 be included) both spine and tympanum are present, and in two specimens both are absent. This agrees with Nobili's results.

The remaining point of difference, namely, the relative size of hand and 
fingers, appears from the measurements given above to be clearly a sexdifference.

Summarising available data in regard to all these characters one finds :-

\begin{tabular}{|c|c|c|c|}
\hline D. sulcata (Forskål) .... & $\begin{array}{l}\text { Meral spine. } \\
\text { Present. }\end{array}$ & $\begin{array}{l}\text { Tympanum. } \\
\text { Absent. }\end{array}$ & $\begin{array}{l}\text { Ratio of H.l. to F.l. } \\
\text { Fingers longer than hand. }\end{array}$ \\
\hline $\begin{array}{l}\text { D. affinis, Alcock, } 1900, \\
\text { 4 specimens, sex not } \\
\text { stated. }\end{array}$ & $\{$ Absent. & Present. & Fingers shorter than hand. \\
\hline
\end{tabular}

Nobili's D. sulcata, 24 o $\mathrm{s}$ Absent in 17. Present in 14. Fingers longer than hand in 24. and 2 s. $\quad$ Present in $3 . \quad$ Absent in 6. Fingers and palm subequal in 2.

Present specimens .... Absent in 11. Present in 8. H.1. (upper bord.) $\div$ F.l. gives for Trace in 1. Trace in 1. $4 \mathrm{gs}$ an average of 2.05 and Present in 1. Absent in 2. range of variation from 2 to $2 \cdot 2 \mathrm{~mm}$.; for 9 os an arerage of 1.55 and range of variation from 1.4 to $1.8 \mathrm{~mm}$.

Alcock does not state the sex of his four specimens; I suggest that they were females. Nobili, though giving the sex of his, does not relate it to finger length, probably the two in which the fingers and hand were subequal were the two females of his collection.

N.B.--I have taken finger length as being the length of the dactylus; hand length might be measured in various ways, I have measured the well-defined upper border, the authors quoted above evidently estimated the less easily measurable "greatest length."

\section{Genus Paraclistostoma, de Man, 1895.}

60. Paraclistostoma leachil (Audouin et Savigny, 1826). See Audonin, 1826, p. 81 ; Savigny, 1826, pl. 2. fig. 1.

Macrophthalmus Leachii, Audouin, loc. cit.; Savigny, loc. cit. Paraclistostoma Leachii, Nobili, 1906, p. 316.

Localities. Station I. A, 1 o probably adult [405], 2 \& ovig. [406, 407]; Station I. E, 2 o probably adult $[408,409], 1$ \& ovig. [410].

Remarks. C.1. $\%$ ovig. $8 \mathrm{~mm}$.

In each $q$ the anterior surface of the propodite of W.L. 3 is hairless, whereas in each $\delta$ it is densely clothed with hair ; this confirms Nobili's suggestion that such a hairy patch is a sex-distinction and not, as regarded by Paulson, a varietal one.

The demarcation of the regions of the carapace varies somewhat in distinctness; the slight difference in Savigny's excellent figures between $\sigma$ and $q$ carapace markings is evidently not a sex-distinction, as in both males in the present collection the transverse line across the branchial region is faintly indicated. 


\section{Genus Macrophthalmus, Latreille, 1829.}

61. Macrophthalmos verraudxi, H. Milne-Edwards, 1848. See Alcock, 1900, p. 377.

Macrophthalmus Ferreauxi, Alcock, loc. cit.

Macrophthalmus Verreauxi, Nobili, 1906, p. 317.

Locality. Station VIII. C, 1 o ovig. [411].

Remarks. C.l. $6 \mathrm{~mm}$., C.b. $9.5 \mathrm{~mm}$., frontal b. between eye-stalks $2 \mathrm{~mm}$., eye-stalk 1 . including eye $7 \cdot 75 \mathrm{~mm}$.

62. Macrophtealmus graefrer, A. Milne-Edwards, 1873. See A. MilneEdwards, 1873 (2), p. 81, pl. 13. fig. 5.

Locality. Station VIII. A, 1 o [412], 5 o [413-417].

Remarks.

\begin{tabular}{|c|c|c|c|c|c|c|}
\hline$\ldots \ldots \ldots$ & $\underset{\substack{\text { o juv. } 413 . \\
7 \cdot 25}}{ }$ & $\begin{array}{c}\text { ㅇo. } 414 . \\
12 \cdot 0\end{array}$ & $\begin{array}{l}\$ 415 . \\
12 \cdot 0\end{array}$ & $\begin{array}{c}\text { qov. } 416 . \\
12.75\end{array}$ & $\begin{array}{l}\text { 오17. } \\
12.75\end{array}$ & $\begin{array}{c}\delta 412 . \\
11 \cdot 0 \mathrm{~mm} .\end{array}$ \\
\hline \multicolumn{7}{|l|}{ C.b. across and in-1 } \\
\hline $\begin{array}{l}\text { cluding outer or- } \\
\text { bital angles .... }\end{array}$ & $12 \cdot 0$ & 215 & $22 \cdot 0$ & 22.75 & 23.75 & $20.25 \mathrm{~mm}$. \\
\hline $\begin{array}{c}\text { Frontal b. between } \\
\text { eye-stalks...... }\end{array}$ & \} 1.5 & $2 \cdot 0$ & $2 \cdot 1$ & $2 \cdot 25$ & $2 \cdot 25$ & $2 \cdot 0 \mathrm{~mm}$ \\
\hline Ch.l. ........... & . & 18.0 & $18: 5$ & $19 \cdot 5$ & $19 \cdot 5$ & $23 \cdot 0 \mathrm{~mm}$ \\
\hline C.b. $\div$ C.l. . & $1 \cdot 65$ & $1 \cdot 79$ & 1.83 & 1.78 & $1 \cdot 86$ & $1 \cdot 84$ \\
\hline Frontal b. $\div$ C.b. .. & $\cdot 12$ & $\cdot 09$ & $\cdot 10$ & $\cdot 10$ & .09 & $\cdot 10$ \\
\hline
\end{tabular}

The only example hitherto recorded is A. Milne-Edwards's type-specimen from Upolu, one of the Samoan Islands. With his description and figures the present specimens agree except in $(a)$ the proportion of length to breadth of the carapace, the measurements in Milne-Edwards's type-specimen, probably a young $q$, being C.1. $7 \mathrm{~mm}$. and C.b. $14 \mathrm{~mm}$.; (b) the granulation of the branchial regions, which is probably more distinct in my specimens; (c) the shape of the abdomen, which in my $\delta$ differs from Milne-Edwards's figure; as, however, the latter represents very well the abdomen of my young o of C.1. 7.25 mm., it appears that Milne-Edwards's figure is wrongly labelled in regard to sex, and that no real difference is involved under this head.

In addition to the points given in Milne-Edwards's description, my specimens have (a) some hair distributed in various places, and (b) some granulation on the walkingmlegs. In detail, hair occurs (i.) on lateral borders of the carapace; (ii.) on upper border of the merus of 1st, 2nd, and 3rd pairs of walking-legs; (iii.) on both borders of the 4th pair of walking-legs, except that it is almost absent from the lower border of the carpus and distal half of the lower border of the merus ; on this 4th pair, moreover, the hair is more strongly developed than on the meri of the first three pairs; (iv.) in all the fomales on the upper border of the clieliped and flanking the 
margins of the apposed borders of the fingers. The granulation occurs on both borders of the meri, the upper borders of the carpi, and both borders of the propi of the walking-legs, also traces on outer surface of the 3rd and 4th pairs more particularly; the granulation of the lower borders of the meri of the $2 \mathrm{nd}$ and 3rd pairs of walking-legs is visible to the naked eye.

Perhaps an important point about $M$. graeffei (my specimens included) is that the eye-stalk extends just beyond the tip of the outer orbital tooth (for a distance approximately equal to the length of the tooth) ending in a blunt point or tubercle drawn out distal to the pigmented region. The spiniform outer orbital tooth reaches to about the middle of the pigmented region.

Macrophthalmus graeffei is ovidently closely related to $M$. converus, Stimpson, 1858 (Stimpson, 1907, p. 97, pl. 13. fig. $2 a-b$ ), and $M$. inermis, A. Milne-Edwards, 1867 (A. Milne-Edwards, 1873 (1), p. 277, pl. 12. figs. $5,5 a$ ), but differs from both in (a) the relative length of the eye-stalks, which in both the latter do not extend beyond the orbit and so fall short of the tip of the outer orbital tooth; $(b)$ the more spiniform and more transversely disposed character of the antero-lateral teeth of the carapace; this is particularly seen in the 1st, $i . \epsilon$. the outer orbital angle, since this is the largest, but is also well seen in the second one ; (c) the merus of each of the first three pairs of walking-legs bears a subterminal tooth; in $M$. convexus the merus of the 4th pair also has such a tooth, though, in five specimens from the Andaman Islands described by Alcock, it was absent not only from the fourth pair, but also from the first pair ; in $M$. inermis none of the meri of walkinglegs benr such a tooth.

$M$. graeffei ngrees with $M$. inermis and differs from $M$. convexus in the degree of pilosity of the inner surface of the chelæ. In all three the inner surface of the fingers is pilose, but while the inner surface of the hand is pilose also in $M$. convexus the pilosity is confined in $M$. inermis and in $M$. graeffei to the distal margin bordering the fingers (see Milne-Edwards's figure of both, loc. cit.). I give outlines from photographs of chelipeds of $\delta$ and $q$ specimens of $M$. graeffei.

Alcock's treatment of $M$. inermis as a synonym of $M$. convexus appears to me to be open to question. The two species agree in the length of the eyestalks as well as in many other ways, but Milne-Edwards's text and figure both describe $M$. inermis as having only two antero-lateral teeth on the carapace; the difference in subterminal meral spines of walking-legs and in pilosity of the inner surface of the hand have been noted above, and a comparison of the figures of Milne-Edwards and Stimpson suggests various points of difference in carapace form.

I find also that Rathbun (1906, p. 834 ), in recording $M$. inermis from the Hawaiian Islands, states very definitely her view that it is quite another species from $M$. convexus, 
Fig. 5 .
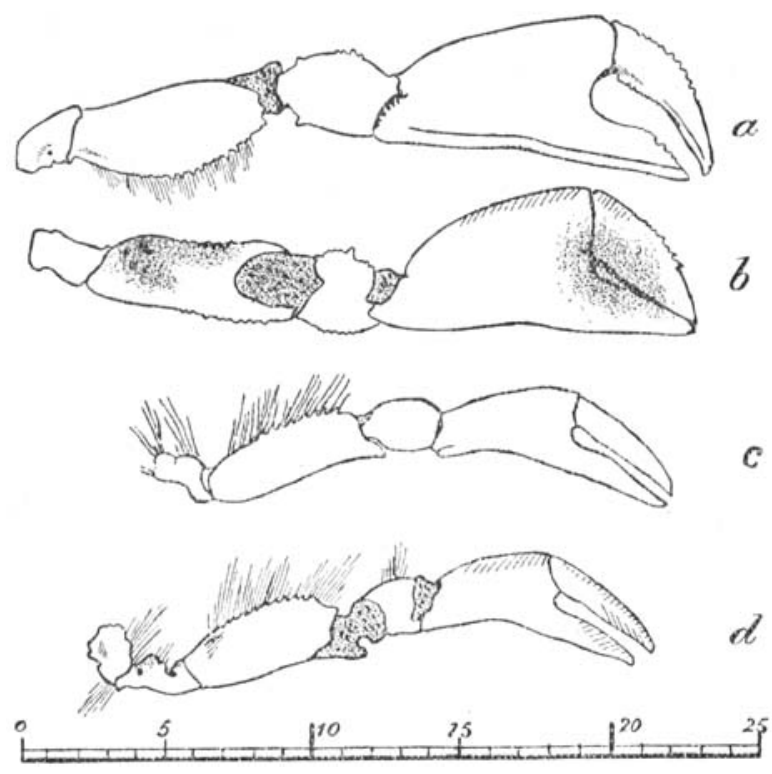

Macrophthalmus graeffei.

a. Right cheliped, o 412: outer surface, setæe removed from gape of fingers.

b. Left cheliped, $\delta 412$ : inner surface.

c. Right cheliped, 우 ov. 414 : outer surface.

$d$. Left cheliped, $ᄋ$ ov. 414 : inner surface.

(Each division of the enlarged scale represents $1 \mathrm{~mm}$.)

63. Macrophthalmus DePressus, Rüppell, 1830. See Alcock, 1900, p. 380.

Macrophthalmus depressus, Nobili, 1906, p. 318.

Macrophthalmus depressus, Nobili, 1907, p. 155.

Locality. Station I. B, 1 ð [418], 1 o [419].

Remarks. The female is non-ovigerous, but probably adult, C.l. $10 \mathrm{~mm}$.; the male also is probably adult, C..l. $11 \mathrm{~mm}$.

\section{Family GRAPSID正.}

Genus Metopograpsus, H. Milne-Edwards, 1853.

64. Metopograpsus Messor (Forskål, 1775). See Alcock, 1900, p. 397.

Metopograpsus messor, Nobili, 1906, p. 320.

Metopograpsus thukuhar, Stimpson *, 1907, p. 114, and synonymy.

Metopograpsus messor, var. frontalis, Miers, 1880, p. 311.

* Stimpson includes a reference to "Metopegrapsus thukuhar Milne Edwards, Mélanges Carcinologiques, p. 131." I do not know the latter publication under the title given, but internal evidence shows that the reference is equivalent to H. Milne-Edwards, 1853, p. 165 , 
Localities. Station I. A, 1 o [420], 2 \& [421, 422]; Station I. B, 1 \% [423], 3 क [424-426]; Station I. E, 3 o [427-429], 1 \% [430].

Remarks. Miers observed "some variation in the width of the front in this species," and one of the characters of his var. frontalis is its wide front, this being "almost three and a half times the length of the upper orbital margin." I give, therefore, the following measurements and ratios :-

\begin{tabular}{|c|c|c|c|c|c|c|c|c|c|c|c|}
\hline & 424 ㅇ․․ & 42 & 69 & & & \pm & 68 & & & & \\
\hline c.l. & $11 \cdot 75$ & 1675 & $17^{\circ} 0$ & $18 \cdot 5$ & $20 \cdot 25$ & $21 \cdot 0$ & $10 \cdot 0$ & 165 & $21 \cdot 0$ & $23 \cdot 0$ & $27.0 \mathrm{~mm}$ \\
\hline 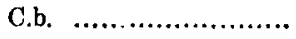 & 16.0 & $2 \cdot \cdot 0$ & $23 \cdot 0$ & $24 \cdot 5$ & $26 \cdot 25$ & $28 \cdot 0$ & $14 \cdot 0$ & $21 \cdot 25$ & 26.75 & 29.25 & $35.0 \mathrm{~mm}$. \\
\hline Frontal b... & $10 \cdot 0$ & $14 \cdot 25$ & $15 \cdot 0$ & $16 \cdot 0$ & 170 & $17 \cdot 5$ & $8 \cdot 8$ & 135 & $17 \cdot 5$ & $19 \cdot 25$ & $22 \cdot 0 \mathrm{~mm}$ \\
\hline Major diameter & 3.5 & $4 \cdot 5$ & 4.5 & $4 \cdot 75$ & $5 \cdot 25$ & $5 \cdot 5$ & $3 \cdot 0$ & $4: 5$ & $5 \cdot 75$ & $5 \cdot 5$ & $6.5 \mathrm{~mm}$. \\
\hline Diam. orb. $\div$ frontal b. .. & .35 & .31 & .30 & 30 & .31 & $\cdot 31$ & 34 & $\cdot 33$ & $\cdot 33$ & .28 & $\cdot 30$ \\
\hline
\end{tabular}

It will be noted that the ratio greatest diameter of orbit $\div$ frontal breadth is less in the larger forms. In specimen 429 the ratio is as in var, frontalis, but the margin of the front has the characteristically sinuous form and not the straight character of var. frontalis.

\section{Family PALICID平.}

Genus Palicus, Philippi, 1838.

65. Palicts whitei (Miers, 1884). See Alcock, 1900, p. 453.

Palicus Whitei, Alcock, loc. cit.

Palicts whitei, Rathbun, 1911, p. 240.

Locality. Station II., 1 ㅇ ovig. [431].

Remarks. C.1. $14 \mathrm{~mm}$. Although this species is easily separated from the allied jukesii of White by the character of the walking-legs and by other characters also, it should not be overlooked that there is indeed a crest or carina on the upper border of the carpopodites and propodites of the first three pairs of walking-legs, though, of course, of very slight dimensions as compared with that in $P$. jukesii; Alcock appears rather to overlook this point.

Miers's figure (Miers, 1884, pl. 49. fig. C) gives an excellent idea of the present specimen.

A good account and drawings of $P$. whitei are given by Calman (Calman, 1900, p. 31, pl. 2. figs. 14-19).

LINN. JOURN.-ZZOOLOGY, VOL. XXXI. 


\section{EXPLANATION OF THE PLATES.}

\section{Plate 42.}

Fig. 1. Chlorodopsis arabica, n. sp. of specimen (o 204). $\times 5$. Text, p. 450.

1a. Do. do. Ventral view of anterior region of same specimen. $\times 5$.

1b. Do. do. Abdomen of same specimen. $\times 6$.

Prate 43.

Fig. 1. Xantho hydrophilus (Herbst, 1790). W alking-leg, enlarged. 'Text, p. 444.

2. Chlorodopsis arabica, n. sp. First pair of abdominal appendages of $\delta$ specimen (o 204). $\times 6 \frac{1}{4}$. Text, p. 450 .

3a. Chlorodopsis spinipes (Heller, 1861). Left chela ơ (o 222, C.l. 5.25 mm.), outer surface. $\times 6 \frac{\Sigma}{2}$ (actual length lower border $5.5 \mathrm{~mm}$.). Text, p. 455 .

36. Do. do. Right cheln of same specimen, outer surface. $\times 6 \frac{1}{2}$ (actual length lower border $5.75 \mathrm{~mm}$.).

3c. Do do. Left chela $q$ ( $q$ ovig. 218, C.1. $5 \mathrm{~mm}$.), outer surface. $\times 6 \frac{1}{2}$ (actual length lower border $5 \mathrm{~mm}$.).

3 d. Chlorodopsis spinipes (Heller, 1861). Right chela of same specimen, outer surface. $\times 6 \frac{1}{2}$ (actual length lower border $5.5 \mathrm{~mm}$.).

4a. Chlorodopsis arabica, n. sp. Left chela $\delta(\delta 203$, C.l. $8.5 \mathrm{~mm}$.), outer surface. $\times 6 \frac{1}{2}$ (actual length lower border $9.5 \mathrm{~mm}$.). Text, p. 450.

4b. Do. do. Right chela of same specimen, outer surface. $\times 6 \frac{1}{2}$ (actual length lower border $9 \mathrm{~mm}$.).

4c. Do. do.

Left cheln of $q$ specimen ( $q 211$, D.1. $7.5 \mathrm{~mm}$.), outer surface. $\times 7$ (actual length lower border $6.5 \mathrm{~mm}$.).

4d. Do. do. Right chela of same specimen, outer surface. $\times 7$ (actual length lower border $6.5 \mathrm{~mm}$.).

\section{Plate 44}

Fig. 1. Lupa alcocki (Nob., 1905). $\quad$ o. $\quad \times 3 \frac{1}{3}$. Text, p. 438.

1a. Do. do. Ventral view of anterior region of same specimen. $\times 10$.

16. Do. do. Anterior view of antero-ventral region of same specimen. $\times 10$.

1 c. Do. do. Abdomen of same specimen. $\times 4$.

2. Herbstia corniculata, Klunz., 1906. Left hand $\delta . \times 10$. 'T'ext, p. 431.

3. Cyphocarcinus minutus, A. M.-Edw., 1868. ㅇ 42, side view. $\times 11 \frac{1}{2}$. Text, p. 433. 


\section{Plate 45.}

Fir. 1. Caphyra monticellii, Nob., 1901. Specimen $48 . \times 5 . \quad$ Text, p. 437.

1a. Do. do. Ventral view of anterior region of same specimen. $\times 11$.

2. Lithocheira integra (Miers, 1884). Ovig. $\$ 383$ showing sharply turned down front etc. $\times 12$. Text, p. 464 .

3. Ostracotheres cynthice, Nob., 1905. $\quad$ o $390 . \quad \times 5 \frac{1}{2}$. Text, p. 465.

$3 a$. Do. do. Ventral view of anterior region of same specimen. $\times 8$.

$3 b$. Do. do. Abdomen of same specimen. $\times 5 \frac{1}{2}$.

4. Ophthalmias curvirostris (A. M.-Edw., 1865). External maxillipedes ( $q$ ovig. 41, C.I. excluding rostral horns $23 \mathrm{~mm}$.). $\times 5 \frac{1}{4}$. Text, p. 431.

5. Ophthalmias cervicornis (Herbst, 1803). External maxillipedes ( $q$ orig. from Cheval Paar, Gulf of Manaar, C.l. excluding rostral horns $39 \mathrm{~mm}$.). $\times 3 \frac{3}{4}$. Text, p. 432. 


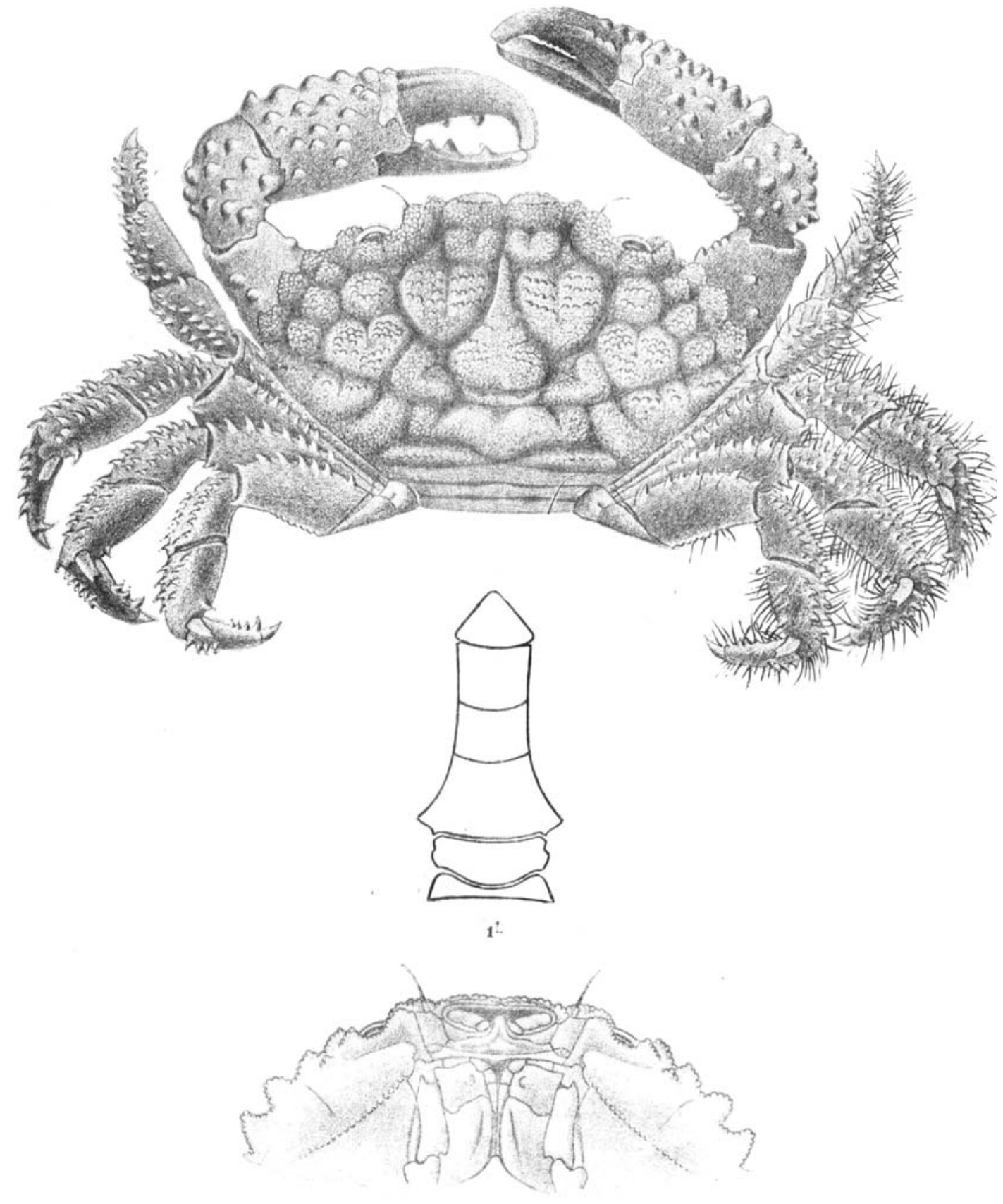

13

SUDAN BRACHYURA. 
LAURIE.

JOUR. LINN. SOC., ZOOL. VOL, XXXI. PL. 43
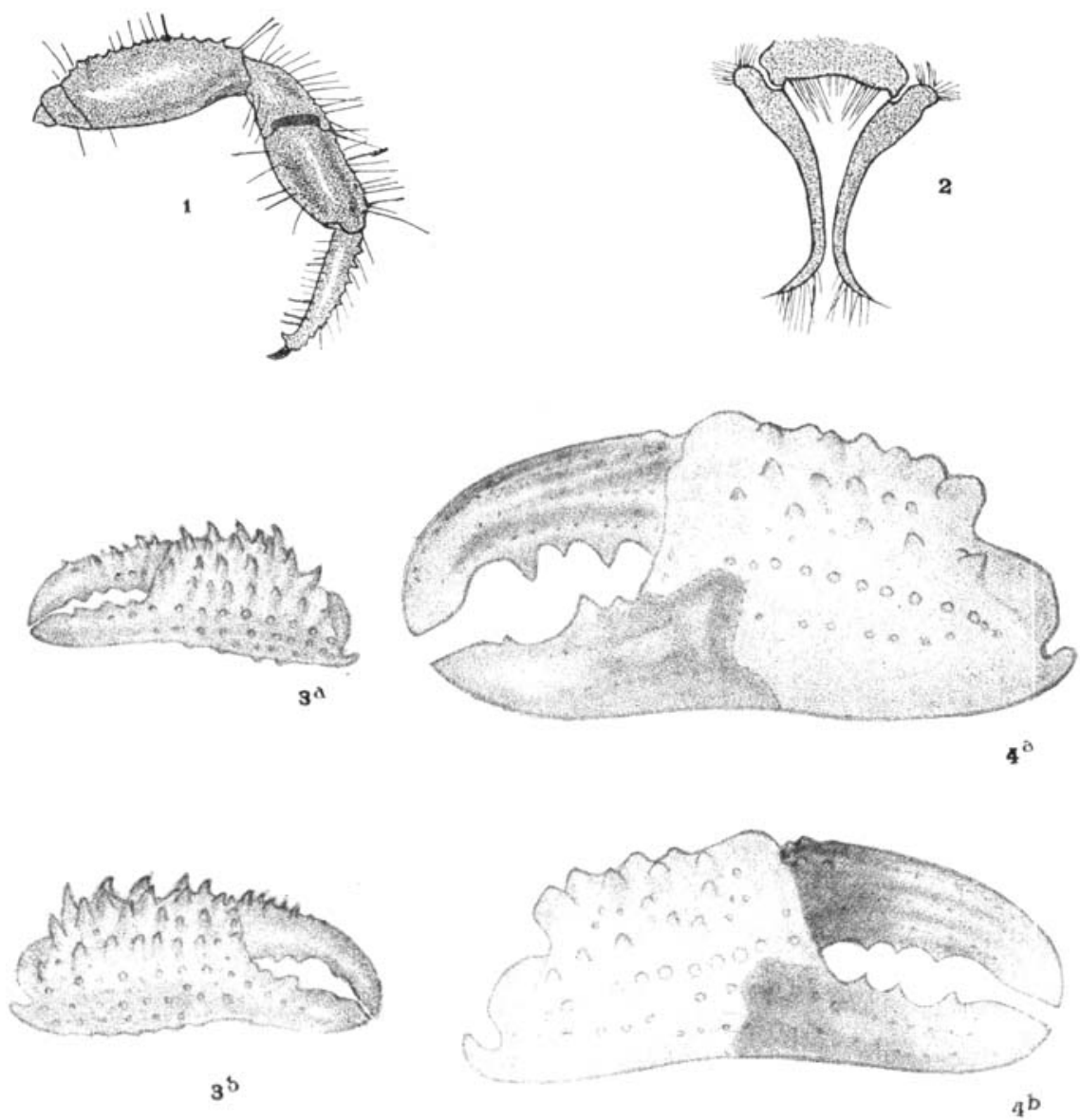

$3^{3}$
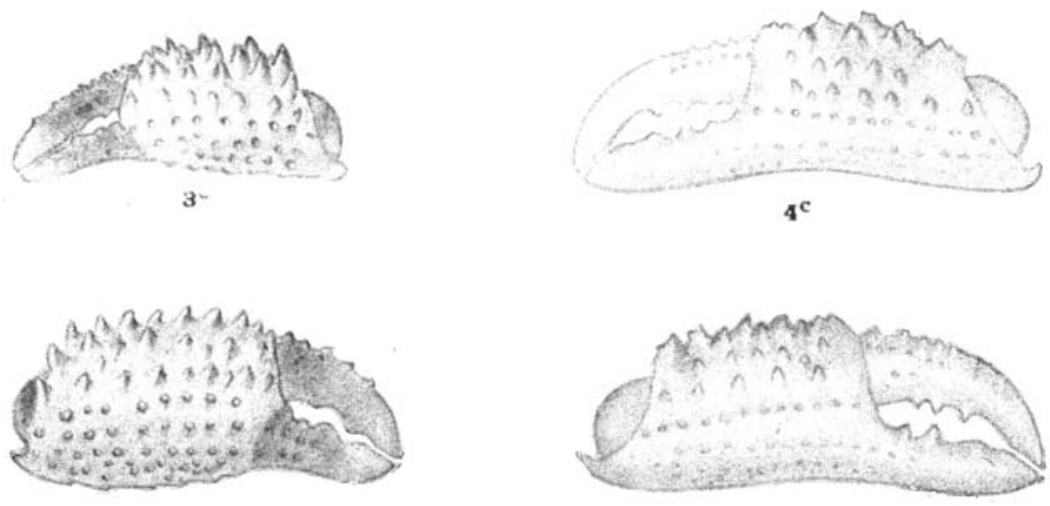

$4^{\mathrm{d}}$

SUDAN BRACHYURA.

Grout, photo ac. 

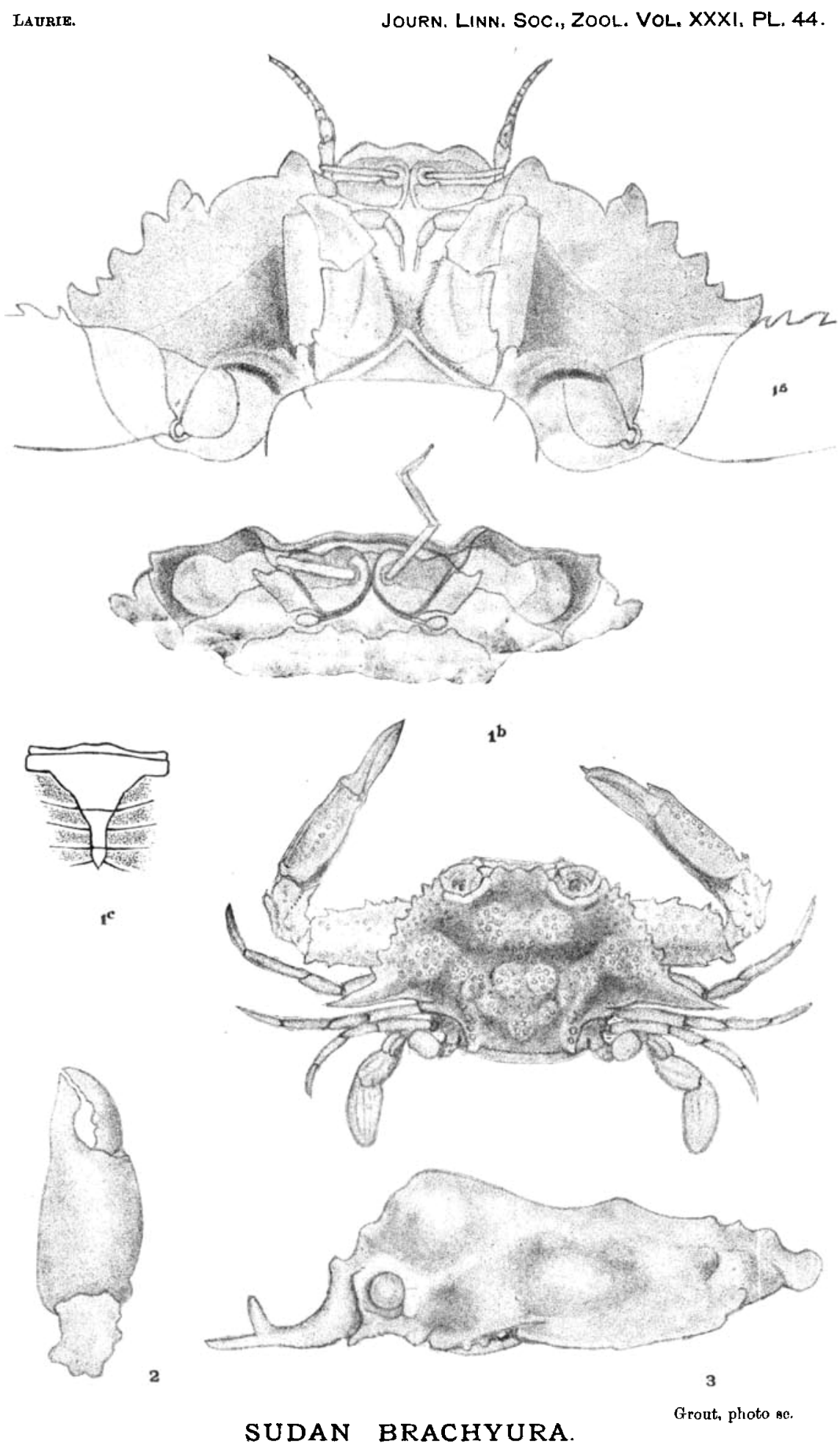

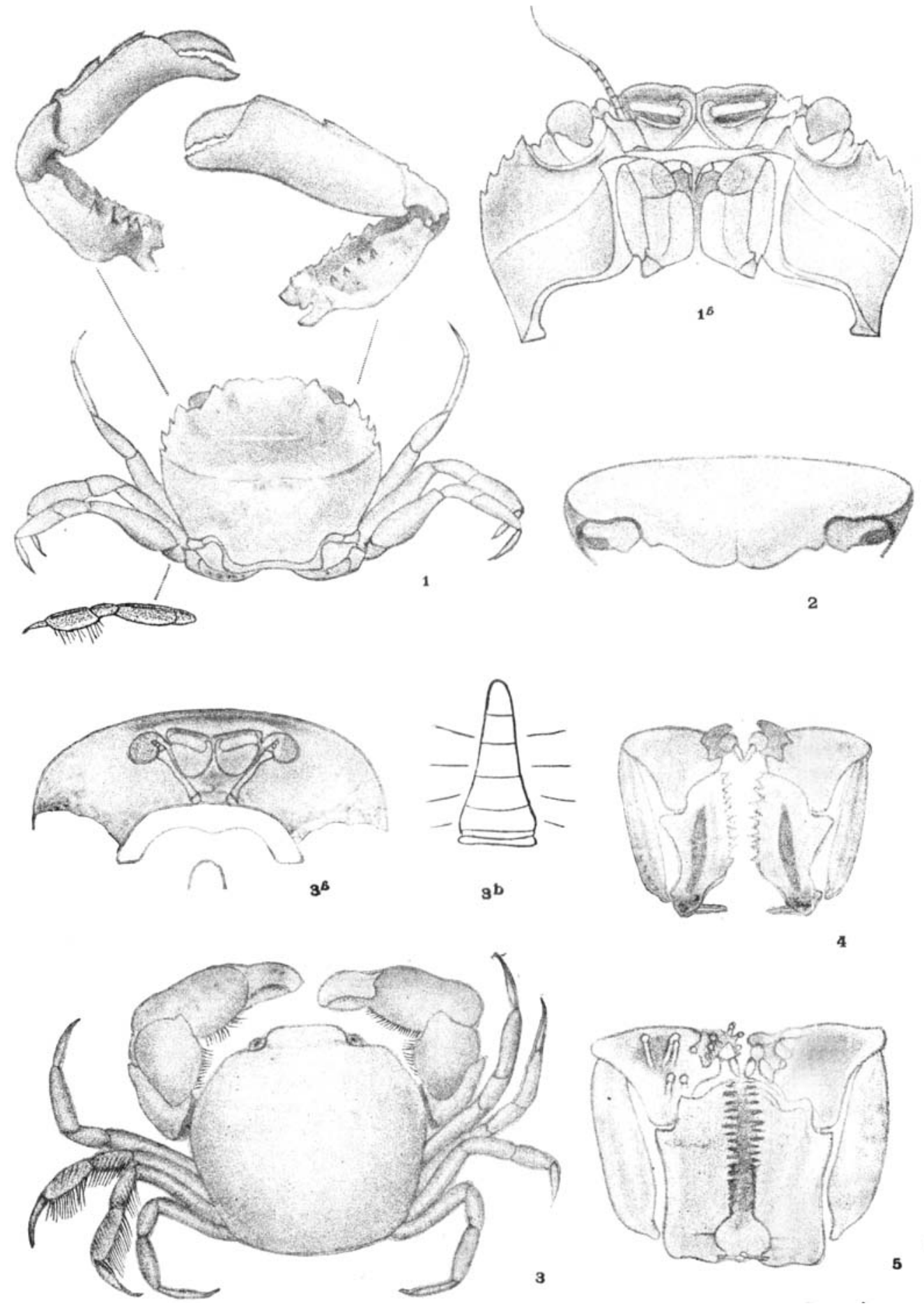

SUDAN BRACHYURA.

Grout, whoto se. 